\title{
AUTORÍA MEDIATA UN ESTUDIO A LA LUZ DE LA CONCEPCIÓN SIGNIFICATIVA DEL DELITO (Y DEL CP ESPAÑOL)
}

\author{
Carlos Martínez-Buján Pérez*
}

Resumen: Se analiza la autoría mediata en el seno de la teoría jurídica del delito a partir de las novedosas premisas que ofrece la concepción significativa de la acción, elaborada primigeniamente por VIVES ANTÓN, que comporta extraer unas consecuencias que se apartan en algunos aspectos de las obtenidas por la doctrina y jurisprudencia mayoritarias. Paralelamente, respetando los postulados básicos de dicha concepción, se proponen unas reglas interpretativas en materia de autoría que, teniendo pleno acomodo en el Código penal español, permiten obtener unas consecuencias político-criminales satisfactorias.

Palabras clave: Autoría mediata. Concepción significativa de la acción. Tentativa. Realización y ejecución del hecho. Participación. Accesoriedad de la participación.

Recibido: septiembre 2018. Aceptado: septiembre 2018

* Catedrático de Derecho Penal.

Facultad de Derecho, Universidade da Coruña, Campus de Elviña, 15071, A Coruña. E-mail: cmbujanp@udc.es 


\title{
INDIRECT PERPETRATORSHIP \\ A STUDY ON THE BASIS OF THE SIGNIFICANT CONCEPT \\ OF LEGAL CRIME THEORY
}

\begin{abstract}
Indirect Perpetratorship is analyzed within the framework of legal crime theory on the basis of the new premises offered up by the meaningful conception significant of the action, elaborated primarily by VIVES ANTÓN, permitting the drawing up of conclusions which in some aspects deviate from those obtained within the most widely accepted doctrines and jurisprudence. At the same time, respecting the basic hypothesis of this conception, a series of interpretative rules are put forward within the field of Perpetratorship which, while adjusting perfectly to the Spanish Penal Code, enable us to obtain satisfactory political-criminal consequences.
\end{abstract}

Keywords: Indirect Perpetratorship. Significant conception of the action. Attempt. Realization and execution of the deed. Participation. Accesory to the participation.

\section{Introducción. El punto de partida: autoría y realización/ ejecución (objetiva) del significado específico del hecho}

Si bien es cierto que cabe hablar de autoría en sentidos diversos, hay, ante todo, un plano básico, esto es, el plano lógico (no valorativo) de la determinación de quién lleva a cabo el hecho definido en un tipo penal, que es lo único que es susceptible de hacerse: en otras palabras, se trata de un problema que, en el seno de la teoría jurídica del delito, va vinculado exclusivamente a la acción ${ }^{1}$.

Así pues, el punto de partida (idea rectora) para la determinación del concepto de autor desde la perspectiva de la concepción significativa únicamente puede venir dado por una

1 Vid. VIVES, Fundamentos, 2011, cit., pp. 784, 791 y 794. No se trata, pues, de dilucidar la cuestión sustantiva de a quién cabe atribuir mayor responsabilidad por la realización de un hecho, sino la cuestión más limitada, por ser puramente conceptual, de a quién cabe tener por autor (cfr. VIVES, "Principios", cit., p. 281, en referencia a la definición del art. 28 CP). Vid. además GÓRRIZ, 2008, pp. 67 ss. y 437 ss. 
perspectiva objetivo-formal, que se caracteriza por delimitar la autoría a partir del significado del verbo (o, en su caso, verbos) típico y que es la perspectiva que también adopta inequívocamente el legislador español en su definición de autor en el párrafo primero del art. $28 \mathrm{CP}$, en el que se indica que la conducta propia del autor es realizar el hecho. Por lo demás, este verbo debe entenderse como equivalente a ejecutar, en el sentido que sirve para caracterizar la tentativa a tenor del art. $16 \mathrm{CP}$, entendimiento que, obviamente, aportará criterios materiales que posibilitarán restringir el concepto de autor ${ }^{2}$.

Se produce, así, una superposición parcial entre la problemática de la autoría y la de la tentativa, desde el momento en que existe una identificación entre realización del hecho y actos ejecutivos en sentido estricto, de tal manera que el principio de ejecución que da lugar a la tentativa coincide en su contenido con los aspectos propios de la autoría, con lo cual, a su vez, actos preparatorios y actos de participación coinciden en la característica de que no alcanzan el nivel de realización o ejecución del tipo.

En síntesis, el concepto lógico-gramatical de autor presupone la realización de una acción objetivamente constitutiva de -cuando meno- una tentativa, y la realización de esta acción no exige, pues, la comprobación de la infracción de la norma personal de conducta.

No obstante, lo que sí pertenece al tipo de acción de la tentativa es la intención de consumar el hecho típico, puesto que este elemento subjetivo no se identifica con el dolo sino que es un genuino elemento definitorio del propio tipo de acción, que pertenece a la pretensión de relevancia. En efecto, una cosa es el dolo de la tentativa, que ha de abarcar el conocimiento y la voluntad de realizar una parte o la totalidad de los actos ejecutivos, y otra cosa diferente es la intención de consumar el hecho típi-

2 Vid. MARTÍNEZ-BUJÁN PÉREZ, C., "Autoría y realización/ejecución (objetiva y positiva) del significado específico del hecho", en LH Morillas Cueva, Madrid 2018, pp. 419 ss., y bibliografía que se cita. 
co, distinción que cobra verdaderamente trascendencia desde la perspectiva de la concepción significativa, en la que el especial elemento subjetivo del tipo (integrado aquí por la resolución de consumar el hecho típico) y el dolo cumplen funciones distintas y se incluyen en niveles sistemáticos diferentes de la teoría del delito: el primero, en la pretensión de relevancia y el segundo, en la pretensión de ilicitud.

Al partir de un concepto formal, basado en la idea rectora de la "realización típica", la caracterización que aquí se acoge es incompatible ya, de entrada, con cualquier perspectiva de carácter estricta o constitutivamente material, como sucede, en particular, con todas las tesis que se basan en la idea del dominio del hecho (incluyendo aun la versión más restrictiva según la formulación de ROXIN), o en ideas afines, como la de la pertenencia del delito, sustentada por MIR, o, en fin, y por descontado, con las tesis que se fundamentan en la idea de la competencia (o dominio competencial del hecho), en el sentido formulado primigeniamente por JAKOBS.

El concepto de autor que se deriva de la concepción significativa, aparte de ser un concepto básicamente formal, es además un concepto puramente objetivo, en el sentido de que no incluye la infracción de la norma personal de conducta. En efecto, en la caracterización más básica que estoy analizando, la autoría es un elemento del tipo de acción, que se inscribe en la primera pretensión de validez de la norma penal, la pretensión de relevancia, y que, por tanto, no incluye entre sus elementos el dolo y la imprudencia, habida cuenta de que estos quedan incardinados en la antijuridicidad formal, correspondiente a otra pretensión diferente de validez de la norma penal, la pretensión de ilicitud. Se trata, pues, de un concepto común a delitos dolosos e imprudente.

Por lo demás, la caracterización objetivo-formal de la autoría y la identificación entre los binomios autoría/realización y tentativa/ejecución (derivada de la concepción significativa) va anudada al criterio de la accesoriedad cualitativa mínima objetiva para el castigo de la participación: por tanto, la norma que 
sirve de referencia para el castigo de la participación (así como para las actuaciones defensivas de terceros y para la imposición de medidas de seguridad) es la norma que refleja la antijuridicidad material, o sea, la realización de un tipo de acción materialmente $\mathrm{u}$ objetivamente antijurídico, sin que deba tomarse en consideración la infracción de la norma personal de conducta (que se integra en el pretensión de ilicitud o antijuridicidad formal). De este modo, las posibles lagunas de punibilidad se reducirán significativamente con relación a la tesis mayoritaria, que acoge el criterio de la accesoriedad limitada.

Sentado lo que antecede, conforme al presupuesto metodológico de la concepción significativa, es preciso recordar que el lenguaje no posee un fundamento que determine el significado, en virtud de lo cual lo que da sentido a los signos lingüísticos que utilizamos es el uso que hacemos de ellos y no los conceptos e ideas que a través de ellos se expresan, los cuales son, por tanto, un producto del uso del lenguaje y no un fundamento de ese uso. Se comprenderá entonces que el camino adecuado para fijar el significado de los términos típicos, y, por ende, para establecer quién realiza en cada caso la acción típica, es atender al uso del lenguaje en los casos (o tipos de casos) concretos, y no a través de la búsqueda de un sedicente término general o elemento común a todos los posibles significados (un pretendido concepto general material de autor, en el supuesto que nos ocupa), dado que con este último método se abandonan como irrelevantes los casos concretos, que son los únicos que pueden ayudar a comprender el uso del término general. En suma, el "núcleo duro" (en expresión de WITTGENSTEIN) que posibilita seguir una regla se concreta de caso en caso y constituye ya el presupuesto del significado.

Si autoría es, en el sentido lógico-gramatical que ahora nos interesa, una categoría de la realización de la acción y si no existe un sentido general que pueda definir en todo caso el concepto de acción (ni el de causa, ni el de ejecución), sino una diversidad de conductas, de las que pueden extraerse sentidos concretos, tampoco podrá existir un concepto que, con carácter 
general, nos indique quién realiza dicho sentido. En suma, no puede haber un concepto general (material) de autor.

Por tanto, a partir de este postulado la delimitación del concepto de autor deberá llevarse a cabo merced a un proceso de interpretación de los diversos verbos típicos, conforme al uso común del lenguaje. Una vez aprehendido el sentido de las diferentes conductas que se describen en los tipos penales, podrá averiguarse quién es la persona que realiza el sentido de la acción, o, dicho con más precisión, quién es el sujeto que realiza, parcial o totalmente, el sustrato de la conducta (activa u omisiva) a la que quepa atribuir el significado del comportamiento que se describe en el tipo de acción descrito en la ley.

A tal efecto, habrá que partir de la zona indudable de significado del concreto tipo de acción de que se trate (si se quiere, de su núcleo), atendiendo al uso común de los términos del lenguaje y al contexto de uso en el que se aplican (y a la vista también del grado de ofensa al bien jurídico protegido y del plan del sujeto expresado en la acción), con el fin de determinar a partir de qué momento se da comienzo a la ejecución y quién realiza el sentido inherente a dicha ejecución, y, en su caso, qué conductas más alejadas de dicho núcleo comparten también su significado. En suma, al vincularse a la tentativa, la caracterización de la autoría nos remite necesariamente a ulteriores criterios materiales (de imputación objetiva) propios del tipo de acción específico de que se trate: téngase en cuenta, una vez más, que el autor ha de realizar un concreto tipo de acción, o sea, una conducta típicamente relevante y ofensiva para un bien jurídico penal.

\section{Caracterización del autor mediato}

A la vista de la regulación del art. $28 \mathrm{CP}$, que introduce esta modalidad de autoría en el texto legal español ${ }^{3}$, el autor mediato es un verdadero autor (un autor en sentido estricto),

3 Con anterioridad a la publicación del CP de 1995 la doctrina española dominante venía solicitando el reconocimiento legal de esta forma de autoría con 
que, indudablemente, realiza o ejecuta ${ }^{4}$ el hecho previsto en el correspondiente tipo de la Parte especial como propio ${ }^{5}$ con los requisitos más arriba apuntados, con la única particularidad de que no realiza el tipo él solo de manera inmediata ni lo realiza

el fin de evitar la impunidad de la persona de atrás en aquellos supuestos en los que el instrumento realizaba una conducta sin dolo o imprudencia o una conducta justificada, al mantener como criterio para admitir la participación el principio de la accesoriedad limitada (vid. referencias, por todos, en HERNÁNDEZ PLASENCIA, 1996, pp. 52 ss.; BOLEA, 2000, pp. 124 ss.; SAINZ-CANTERO CAPARRÓS, 2001, p. 92). Sin embargo, conforme a las premisas de la concepción significativa y al principio de la accesoriedad mínima objetiva, tal necesidad político-criminal queda muy relativizada.

4 Tras la mención expresa de la autoría mediata en el art. $28 \mathrm{CP}$, algunos penalistas han apuntado la incompatibilidad de la teoría objetivo formal con la nueva regulación del CP español (así, LÓPEZ BARJA DE QUIROGA, 1996, pp. 38 s.) o, al menos, la mejor compatibilidad con un concepto objetivo-material que con uno formal (así, PÉREZ ALONSO, 1998, pp. 405 s.). Sin embargo, me parece obvio entender que lo que plasma el párrafo primero del art. 28 es precisamente el postulado básico de la teoría objetivoformal, a saber, que es autor aquel que realiza el hecho típico. Vid. en este sentido, por todos, DÍAZ G.-CONLLEDO, 2002-a, p. 444, quien, acertadamente, recuerda que la pretendida incompatibilidad de la teoría objetivoformal con la autoría mediata (o con la coautoría) parten de la errónea base de atribuir a esta teoría la idea de que el tipo solo se puede realizar de modo físico-corporal directamente (y solo individualmente), idea que no es -ni mucho menos- consustancial a un concepto objetivo-formal (vid. además ampliamente DÍAZ G.-CONLLEDO, 1991, pp. 467 ss.) y desde luego, no lo es al concepto significativo que aquí mantengo.

5 En el art. 13-1 de la Propuesta de Eurodelitos, conforme a la redacción pergeñada por TIEDEMANN y SCHÜNEMANN, también se reconoce la autoría mediata como una genuina forma de autoría. En efecto, tras establecerse en el primer inciso que "es autor quien mediante un comportamiento propio realiza el hecho sólo o conjuntamente con otros", se señala a renglón seguido, en el segundo inciso, que "también es autor quien utiliza como instrumento a otro para la realización del hecho (autoría mediata, art. 14)". Sobre la figura de la autoría mediata en la Propuesta de Eurodelitos vid. TIEDEMANN, 2000, pp. 93 s., donde subraya que "la -renovada- necesidad de una regulación expresa de la autoría mediata deriva en el marco europeo ya de la idea de que esta figura jurídica quiebra el pensamiento de la accesoriedad y por ello se encuentra inmersa en el constante riesgo de perder, en la aplicación práctica del Derecho, los necesarios contornos". 


\section{conjuntamente con otros (coautores) $)^{6}$, sino que "se sirve de otra persona como instrumento"?.}

6 Lo que se indica en el texto no obsta, evidentemente, a la posibilidad de que exista también una coautoría mediata, caracterizada por la realización conjunta de un tipo penal por parte de varios sujetos que se sirven de otro (o de otros) que actúa (actúan) como instrumento. Cfr. en igual sentido DÍAZ G.- CONLLEDO, 2001, p. 29, quien acertadamente subraya que, al ser la autoría mediata una forma de autoría en sentido estricto, habrá de reunir todos los requisitos de esta. Por tanto, conforme a la perspectiva que aquí he asumido, el autor mediato deberá realizar objetiva y positivamente el significado específico del tipo penal de que se trate.

Por lo demás, nada se opone, obviamente, a admitir una participación mediata en el caso de que el instrumento lleve a cabo una conducta que no deba ser calificada de autoría sino de simple participación, como, p. ej., forzar al instrumento a prestarle el arma al autor. Vid. por todos LUZÓN, 1990, p. 129; DÍAZ G.-CONLLEDO, 1991, p. 522, y 646 ss.; BOLEA, 2000, p. 158 y 160, n. 45 y 50 .

7 Vid. por todos COBO/VIVES, P.G., p. 748; OCTAVIO DE TOLEDO, 2001, p. 589, quien subraya que el comportamiento del autor mediato queda "abarcado en la tipicidad correspondiente, salvo que del análisis de ésta se extraiga la conclusión contraria: así, con carácter general, en los delitos de propia mano"; se hace eco de ello GÓRRIZ, 2008, p. 191 y n. 343, y p. 210.

Interesa resaltar que, al acoger los postulados de la concepción significativa de la acción, se desemboca en una caracterización restringida de la autoría mediata (cfr. VIVES, 2011, pp. 791 s.), a diferencia de la desmesurada extensión que en ocasiones se le otorga en la doctrina (especialmente a partir de la irrupción del criterio del dominio del hecho por parte de ROXIN) y en la jurisprudencia.

En lo que concierne a la jurisprudencia española, vid. la ilustrativa nota 161 (en 2011, pp. 792 ss.) que agrega VIVES en referencia a los delitos de falsedades, en los que se aplica la autoría mediata como mero expediente con el que se suple la falta de prueba de un elemento del delito, como es la ejecución de la acción típica, conculcando así la presunción de inocencia, cosa que sucede paradigmáticamente en la STS 11-11-08, en la que se condena a un sujeto como autor mediato de un delito de falsedad -del que había sido previamente absuelto- con el argumento de que tenía el "dominio del hecho", aunque no queda claro que, materialmente, hubiese realizado la falsificación que se le imputaba. Por otra parte, en otras ocasiones nuestra jurisprudencia recurre de forma innecesaria a la autoría mediata, al ignorar el verdadero sentido de la acción típica aplicada (vid. de modo también paradigmático la STS 27-4-07), como sucede en el delito de contaminación del art. 325-1, en el que el tipo se define como "provocar o realizar, directa o indirectamente": es obvio que el "provocar" y el "realizar indirectamente" 
Pero, además, de dicha regulación cabe deducir que el autor mediato comienza ya a "realizar" o a "ejecutar" el tipo desde el instante en que empieza a ejercer su actuación sobre el instrumento, habida cuenta de que en ese momento empieza ya a "servirse de" otro, y, por tanto, lleva a cabo una acción de tentativa (esto es, la denominada solución individual o solución del autor mediato $)^{8}$.

Dicho de modo más preciso, la tentativa debe comenzar siempre cuando la persona de atrás pone en marcha el proceso que conducirá a la consumación del hecho delictivo a través de la mediación de la persona de delante ${ }^{9}$, sin que se exija una ul-

permiten englobar supuestos materialmente constitutivos de autoría mediata, pero quien realiza dichas acciones es un auténtico autor directo e inmediato del tipo del art. 325-1.

Vid. también en sentido similar GIMBERNAT, 2013, p. 67, quien, tras criticar la extensión que ha ido adquiriendo la autoría mediata en aplicación de la teoría del dominio del hecho, y rectificando su posición primigenia cuando afirmaba que «la utilidad de esta teoría [del dominio del hecho] para la autoría mediata me parece... fuera de duda» (posición mantenida en 1966, p. 136), en la actualidad sostiene que "como al describir la autoría mediata, el CP no habla para nada de dominio del hecho, sino de 'realiza[r] el hecho por medio de otro del que se sirven como instrumento', creo que lo más conforme con el texto legal sería determinar cuándo, más allá de la inducción y de la cooperación necesaria, se puede afirmar que 'el autor de detrás' ha 'instrumentalizado'al autor inmediato para cometer un delito".

8 Cfr. ya VIVES, 1977, p. 188; COBO/VIVES, P.G., p. 749. Vid. además GÓRRIZ, 2008, pp. 210 s. y 447, OCTAVIO DE TOLEDO, 2004, p. 834, quien aclara que, surgida la instrumentalización, será ya el instrumento quien lleve a cabo todos los demás actos que integren la "ejecución del hecho", pero con la particularidad de que, al poner por obra esa ejecución "al servicio" del autor mediato, será este el que se erija legalmente en el verdadero ejecutor del mismo hecho.

Con todo, esta última opinión debe ser, a mi juicio, matizada en el sentido de que el instrumento también ejecuta el hecho en el sentido más básico, lógico-gramatical, del concepto de autoría, por más que él ponga esa ejecución al servicio del autor mediato, y, por tanto, será "legalmente" también autor, salvo en la hipótesis en la que, si bien lleve a cabo el sustrato material del tipo, realice una conducta atípica. Eso sí, ello no comporta que tenga que ser un autor responsable penalmente, como indico más abajo en el texto.

9 Vid. ya RODRÍGUEZ MOURULLO, 1969, pp. 424 s.; vid. además MIR, P.G., L. 13/65 y L.14/72 ss. 
terior actividad por parte del autor mediato ${ }^{10} \mathrm{y}$, por supuesto, sin que se requiera que el instrumento comience a realizar los actos

10 Vid. en este sentido MIR, ibid., quien realiza además unas certeras reflexiones, en las que descarta, a mi juicio convincentemente, la solución diferenciadora preconizada por ROXIN (y acogida en la doctrina española, entre otros, por ALCÁCER, 2001, pp. 168 ss.; DEMETRIO, 2003, pp. 119 ss., y con importantes matices por HERNÁNDEZ PLASENCIA, 1996, pp. 115 ss.) ante el conocido ejemplo propuesto por el penalista alemán, relativo a la mujer que ha vertido un veneno en la sopa de su marido: si la mujer se marcha, la tentativa comenzaría en el momento que deja servida la sopa (porque la mujer abandona el dominio del hecho y entonces surge un peligro inmediato para el bien jurídico); pero si la mujer permanece al lado del marido esperando que se la tome, la tentativa no comenzaría hasta el momento en que el marido (el instrumento) se la tomara (porque solo a partir de ese instante existe un peligro inmediato para el bien jurídico). En efecto, desde la perspectiva de las premisas de la concepción significativa, me parece decisivo el argumento empleado por MIR para mantener que la tentativa comienza ya en todo caso cuando la mujer sirve la sopa: el control que supone la mera posibilidad de intervenir en el hecho hasta el último momento no implica una realización efectiva de actos ejecutivos, sino tan solo la realización de la posibilidad de interrumpirlos (lo cual no es suficiente para que exista una ejecución); por tanto, la mujer terminó ya su parte de la ejecución al dejar la sopa, con independencia de que después se quede vigilando, o no, si el marido se la toma; el único modo de sostener lo contrario sería concebir este plan ejecutivo como de omisión, pero ello es insostenible al existir un acto doloso previo positivo (verter el veneno) que, por sí mismo, determina positivamente el resultado (vid., sin embargo, críticamente ALCÁCER, 2001, p. 181, pero a partir de la idea del control sobre el riesgo); y en el caso de que la mujer se viese obligada a intervenir posteriormente para que su marido ingiera el veneno, cabrá decir que la ejecución proseguirá, pero no que quedan anulados los actos ejecutivos previamente realizados (transmutándose en meros actos preparatorios) y que empieza en este momento posterior la fase ejecutiva. En fin, al margen del argumento dogmático a la luz de la concepción significativa, también cabe esgrimir el argumento político-criminal aducido por MIR (siguiendo a HERZBERG, 1987, p. 66), a saber, que si la tentativa no empezase en el momento en que se comienza a actuar sobre el instrumento, habría que llegar a la absurda conclusión de que la actuación de la persona de atrás quedaría sin castigo como autoría mediata, mientras que la tentativa de inducción sí sería, en cambio, castigada (en nuestro CP como proposición para delinquir).

Considera discutible que la tentativa del autor mediato solo se inicie cuando comienza la del que actúa inmediatamente: DÍAZ G.-CONLLEDO, 1991, p. 477 , n. 226. 
decisivos. Eso sí, en todo caso hay que exigir que exista en el autor mediato la intención de que el hecho típico se consume ${ }^{11}$.

Por consiguiente, a partir de ese instante, y sin más requisitos, será factible -según las premisas que aquí asumo-castigar al partícipe que hubiese contribuido a la actividad instrumentalizadora del autor mediato, porque ya existe un autor en el sentido lógico-gramatical.

Eso sí, al igual que sucede en relación con el autor inmediato, será en el seno de la pretensión de ilicitud donde se determinará el contenido de la infracción de la norma personal de conducta y, en concreto, si el autor mediato obró con dolo o con imprudencia ${ }^{12}$, puesto que para el concepto lógico-gramatical de

11 Téngase en cuenta que, a mi juicio, este elemento subjetivo, consistente en la finalidad de llegar a la consumación del hecho típico, pertenece al tipo de acción de la tentativa, según expliqué más arriba.

Y repárese en que de este modo adquiere pleno sentido el referido criterio de la solución individual aquí preconizado: si, operando con el ejemplo recogido en la nota anterior, la mujer deja la sopa envenenada encima de la mesa con la intención de que el marido se la tome, es incuestionable, con arreglo a las premisas aquí acogidas, que ella ha iniciado la tentativa de asesinato, con independencia de que permanezca, o no, a su lado. En caso de que la mujer se vaya, podrá, como mucho, afirmarse que se trataba de una tentativa inacabada (si, v.gr., la mujer tuviese la convicción de que su presencia fuese conveniente para conseguir que el marido la ingiriese); con todo, aun en esta hipótesis, lo normal es que la acción de la mujer de dejar la sopa envenenada encima de la mesa suponga ya la práctica de todos los actos que objetivamente deberían producir el resultado (salvo supuestos de laboratorio, como sería la circunstancia de que el marido odiase la sopa, pero entonces la mujer sería más bien una inimputable por notoria imbecilidad a la hora de elegir el medio ejecutivo).

12 Con respecto a la autoría mediata imprudente (conceptualmente aceptada de forma mayoritaria en la doctrina), no veo obstáculo para su admisión en el tenor literal del art. 28 del CP español, puesto que, frente a lo que algunos penalistas esgrimen, la expresión "realizan el hecho ... por medio de otro del que se sirven como instrumento" no encierra una connotación necesariamente dolosa, desde el momento en que en la acepción aquí aplicable del Diccionario de la RAE (acepción 20) "servirse de" (como verbo intransitivo pronominal) significa "valerse de una cosa para el uso propio de ella. Servirse de un martillo" y "valerse" (acepción 16) "usar algo con tiempo y ocasión, o servirse últimamente de ello. Valerse de una herramienta". Por lo 
autor mediato solo es imprescindible acreditar que este se sirve de otra persona como instrumento para realizar un hecho penalmente típico, sin que se exija componente subjetivo de ilicitud alguno: se trata, pues, del mismo concepto de autor (objetivo) que rige para el autor inmediato ${ }^{13}$, y cuya presencia -insisto- es

demás, huelga recordar, una vez más, que las palabras no tienen connotación subjetiva alguna, de tal manera que la subjetividad tendrá que extraerse necesariamente de su uso en un contexto semántico determinado.

$\mathrm{Y}$, desde luego, descartada de plano la idea del dominio del hecho para la fundamentación de la autoría (como aquí hago), desaparece también el argumento material al que suelen recurrir algunos partidarios de dicha idea para rechazar la autoría mediata imprudente, como, v. gr., hace CEREZO (P.G., III, p. 218): "Sólo puede tener el dominio del hecho quien actúe dolosamente. Al sujeto de atrás que actúa imprudentemente, aunque sea con imprudencia consciente (...) le faltan los elementos objetivos y subjetivos del dominio del hecho". Frente a ello cabe recordar que aquí se parte de la base de que la autoría mediata no se caracteriza tanto por la posición predominante de la persona de atrás como por un déficit personal del intermediario (cfr. también en este sentido PEÑARANDA, 1990, p. 294).

Es más, incluso aquellos penalistas que, como HERNÁNDEZ PLASENCIA (1996, pp. 61 y 322 ss.), PÉREZ ALONSO (1998, pp. 405 ss.) o DÍAZ G.-CONLLEDO (1996-2, p. 1291; 2001, p. 54, y EPB, 2002, p. 150,2004 , pp. 53 s.), en principio admiten pretendidos "tintes finalísticos" o "una cierta intencionalidad" en la mencionada expresión del CP español (así como en la expresión "por medio de") que dificultarían la admisión de la autoría mediata imprudente, creen que cabe una interpretación en la que se "objetiven los términos" o, en su caso, proponen acudir en tales supuestos a los tipos de la Parte especial. A favor de admitir la autoría mediata imprudente en el vigente CP español vid. además, entre otros, ya RODRÍGUEZ MOURULLO, 1969, pp. 477 ss., y 1972, pp. 813 ss. y 817 ss.; vid. también COBO/VIVES, P.G., p. 751; LUZÓN, P.G., L. 18/51; PEÑARANDA, 1990, p. 294; PÉREZ MANZANO, 1999, p. 72; también MIR (P.G., L. 14/71) la admite implícita pero inequívocamente: "la posición de inculpabilidad del ejecutor lo subordina al que la utiliza, sobre todo cuando éste la ha provocado intencionalmente".

En cambio, en el art. 14 de la Propuesta de Eurodelitos, según la redacción de TIEDEMANN, no se admite la autoría mediata imprudente, puesto que se establece que "al autor le será imputable el comportamiento de un tercero cuando lo ha originado dolosamente y conoce además que este carece, total o parcialmente de responsabilidad penal (...)".

13 Vid. en sentido coincidente, a partir de su propia concepción de autoría: DÍAZ G.-CONLLEDO, 1991, pp. 645 ss. y 690; también MIR, P.G., L.14/40, n. 38, partiendo de su concepción de la autoría como pertenencia, quien aclara que "el dominio del hecho del autor mediato no procede de que 
la que, a mi juicio, abre ya la posibilidad de castigar a los partícipes que colaboran en la conducta del autor mediato.

Cuestión diferente es determinar cuál es el fundamento material de la autoría mediata. En mi opinión, desde la perspectiva de la caracterización de la autoría a la luz de la concepción significativa (que, asentada en una premisa objetivo-formal, se identifica necesariamente con una conducta de tentativa) cabe afirmar, ante todo, que, ciertamente, el autor mediato debe realizar/ejecutar el hecho, en el sentido de que debe iniciar la tentativa. Así las cosas, admitidos tales postulados, el fundamento material debe verse en la idea de que la persona de atrás pone en marcha un proceso causal ${ }^{14}$ que es objetiva y subjetivamente idóneo para consumar el hecho delictivo. Y para entenderlo así hay que recordar que, de un lado, el autor mediato no solo pone una "auténtica causa material del hecho" o una "condición suficiente del resultado" 15 sino que lo hace con la intención de que este hecho llegue efectivamente a consumarse; y que, de otro lado, el instrumento no es más que un mero eslabón de la cadena causal porque no solo se trata de un sujeto que será penalmente irresponsable, sino que es utilizado por la persona de atrás de modo equivalente ${ }^{16}$ al empleo de un animal o de una fuerza de la naturaleza ${ }^{17}$.

actúe con dolo, sino de que el instrumento desconoce la situación, ya que si éste actuara con dolo privaría al hombre de atrás del dominio del hecho y lo convertiría en partícipe pese a actuar igualmente con dolo".

14 A esta idea de "un proceso causalmente dirigido a la producción del hecho" aludía ya VIVES (1977, pp. 170 s.), con el relevante matiz de que el referido hecho en modo alguno puede ser atribuido al instrumento que lo realiza de propia mano, en la medida en que este "lo lleva a cabo sin libertad".

Ello no obstante, a esta fundamentación propuesta por VIVES (que considero básicamente correcta) deben añadirse las consideraciones que efectúo a continuación en el texto.

15 Expresiones utilizadas por VIVES, 1977, pp. 169 y 182.

16 Obviamente, me interesa matizar que interpreto el verbo equivaler en el sentido que le otorga el Diccionario de la RAE ("dicho de una persona o de una cosa: ser igual a otra en la estimación, valor, potencia o eficacia"). Por tanto, entiendo que cuando VIVES utiliza el vocablo equivalente, no pretende indicar que el instrumento es un animal o una fuerza de la natura- 
Creo que este entendimiento del fundamento material de la autoría mediata permite eludir las objeciones esgrimidas por DÍAZ G.-CONLLEDO a la fundamentación que había propuesto VIVES. En efecto, téngase en cuenta que aquí no me baso en una "idea puramente causal"18, dado que la puesta en marcha del proceso causal idóneo para desembocar en la completa realización del hecho típico, generada por la persona de atrás (si se prefiere, el acceso al tipo), va acompañada de un peligro para el bien jurídico protegido y de un componente subjetivo (que entraña un cierto aspecto de control) en la medida en que el autor mediato actúa con la intención de que dicho hecho se consume, de tal manera que, a su vez, este sujeto siempre podrá desistir eficazmente si evita que el instrumento llegue a consumar el delito.

\section{Caracterización del instrumento}

\subsection{El instrumento siempre realiza el sustrato mate- rial del tipo de acción y puede llegar a realizar el propio tipo de acción y ser autor en sentido lógico-gramatical}

Como ya indiqué anteriormente, en la figura de la autoría mediata el instrumento -además de llevar a cabo una acción

leza, sino que "actúa" de un modo equiparable en su valoración (jurídica) a dichos fenómenos, en virtud de lo cual -según indico más abajo- existe un auténtico instrumento en todos los casos en los que la persona de delante no realiza ya el tipo de acción y, por ende, no puede ser autor en sentido lógico-gramatical, dado que entiendo que en tales casos existe también el déficit personal del intermediario (la expresión es de PEÑARANDA, 1990, p. 294) que caracteriza al genuino instrumento.

17 Esta es la idea rectora apuntada por VIVES, 1996-a, p. 282, idea que comparto. Vid. además COBO/VIVES, P.G., p. 749 n. 41, donde añaden que la actuación del instrumento ha de estar presidida por la necesidad, y que, si no concurren las características apuntadas para la instrumentalización, no habrá en realidad una autoría mediata, sino inducción o complicidad.

18 Como objetaba DÍAZ G.-CONLLEDO (1991, p. 479, n. 229) a la fundamentación de VIVES. 
(humana) ${ }^{19}$ - siempre debe realizar, cuando menos, el sustrato material del tipo de acción, sin que ello implique que tenga que ejecutar el propio tipo de acción, dado que habrá supuestos en los que el instrumento realice una conducta atípica y lleve a cabo solo dicho sustrato material del tipo ${ }^{20}$.

19 La presencia de una acción humana en el instrumento debe considerarse como un presupuesto o requisito previo para la admisión de la autoría mediata, habida cuenta de que, si no hay acción en el pretendido instrumento, la autoría de la persona de atrás no será mediata sino inmediata. Vid. por todos CEREZO, P.G., III, p. 214, n. 36; DÍEZ RIPOLLÉS, P.G., p. 367; HERNÁNDEZ PLASENCIA, 1996, pp. 93 ss.; MIR, P.G., L.14/55

Por ello tal vez sea preciso insistir en que cuando, acogiendo la formulación de VIVES, apuntaba más arriba que en la autoría mediata el instrumento se caracteriza por ser utilizado por la persona de atrás de modo equivalente al empleo de un animal o de una fuerza de la naturaleza, se está partiendo de la premisa de que, en todo caso, realiza una acción en sentido jurídico-penal. Repárese en que cuando VIVES recurre a esta formulación añade que lo decisivo para dicha caracterización es que "la actuación del instrumento ha de estar presidida por la necesidad" (subrayados míos). Creo que la aclaración es pertinente porque en ocasiones se indica en la doctrina (v. gr., CEREZO, ibid.) que no hay acción cuando "se utiliza a un cuerpo humano como podría haberse utilizado cualquier otro tipo de instrumento no humano (un martillo o una piedra)".

20 La naturaleza de la autoría mediata como auténtica autoría se pone de manifiesto precisamente en este caso, en el que solo existe un autor (incluso, en el más básico de los sentidos, el lógico-gramatical), que es el autor mediato. En sentido próximo, vid. COBO/VIVES, P.G., p. 748, si bien su apreciación va referida a la realización de un "injusto típico".

Me interesa insistir en que en esta hipótesis es cierto que el instrumento no lleva a cabo el tipo de acción (en su sentido jurídico) de que se trate, por lo que consecuentemente no puede ser considerado autor, pero no hay duda de que siempre realizará el hecho en su vertiente fáctica. En este sentido hay que entender también la afirmación de DÍAZ, 1991, p. 649, cuando escribe que el instrumento tiene que realizar "una acción que determine objetiva y positivamente el hecho, independientemente de que (...) su conducta sea o no típica" y que esa realización es imprescindible para hacer surgir la autoría mediata. En otras palabras, la actuación del instrumento no puede quedar reducida a un mero factor causal del resultado -como pretenden algunos penalistas al menos para algunos supuestos- como ROXIN. Vid. críticamente, con razón y contundencia, DÍAZ G.-CONLLEDO, 1991, pp. 649 s., subrayando la importancia de la actuación del instrumento para la fundamentación de la autoría mediata. 
Esto último (añado ahora) sucederá siempre en los siguientes casos: en primer lugar, en los tipos de acción que requieran un elemento subjetivo específico para caracterizar la propia acción (en los que cabe la posibilidad de que tal elemento no concurra en el instrumento y solo concurra en la persona de atrás ${ }^{21}$, lo cual conducirá a calificar en todo caso como autor mediato a esa persona de atrás que actúe movida por tal ánimo específico ${ }^{22}$ ); en segundo lugar, en los delitos especiales (en

Es más, sin perjuicio de lo anterior, todavía habría que concretar si el instrumento que actúa realiza una acción objetivamente constitutiva de autoría (con independencia de que, como queda dicho, no llegue a realizar un tipo de acción) o de participación (con independencia también de que, a la postre, no llegue a ser un partícipe penalmente relevante). Vid. DÍAZ G.CONLLEDO, 1991, pp. $646 \mathrm{~s}$.

21 Así, v. gr., en el delito de hurto del art. $234 \mathrm{CP}$ el ánimo de lucro no tiene por qué concurrir en el instrumento, pero sí necesariamente en el autor mediato, quien será entonces el único autor del delito en el sentido lógico-gramatical. En este sentido, pero a partir de otra fundamentación, vid. también MIR, P.G., L.14/64-66.

Con todo, con respecto a este supuesto conviene recordar que, a mi juicio, los tipos de acción que requieren un elemento subjetivo para su definición (como nota conceptual del tipo) son mucho más reducidos de lo que sostiene la opinión doctrinal mayoritaria (sobre los "sedicentes" elementos subjetivos del tipo de acción en el CP español, vid. MARTÍNEZ-BUJÁN, 2013-a, pp. 252 ss.; vid., además, en una línea próxima RAGUÉS, 2017, pp. 817 ss.). Ni que decir tiene que entonces en estos últimos casos (de sedicentes elementos subjetivos del tipo) el tipo de acción se realizará ya plenamente sin la presencia de tal pretendido elemento subjetivo, en virtud de lo cual se puede afirmar que el instrumento también sería autor de dicho tipo en el sentido lógico-gramatical: ello sucederá, por de pronto, en todos los denominados delitos de tendencia intensificada, en los llamados de delitos de expresión y en aquellos casos peculiares de elementos subjetivos (o mixtossubjetivo- objetivos) que, pese a reflejar una "actitud interna", pertenecen a la antijuridicidad; pero también sucederá en muchos de los intitulados delitos de intención.

22 Desde la perspectiva de la concepción significativa es ya conceptualmente incorrecto hablar de un "instrumento doloso sin intención", figura reconocida, empero, por la opinión dominante: y es que, si un sujeto obra sin el específico elemento subjetivo del tipo de acción, no hay tipo, y, por tanto, carece de todo sentido entrar a comprobar si obra con dolo, por mucho que conozca y quiera realizar los elementos objetivos del tipo: si, v. gr., en el 
los que el instrumento no puede realizar el tipo de acción en su totalidad por faltarle la cualidad especial para poder ser sujeto activo $)^{23}$, en cuyo caso cabrá calificar como autor mediato a la persona cualificada de atrás si la persona de delante obra sin libertad o en situación de error o, en todo caso, si se admite la autoría mediata a través del denominado instrumento doloso no cualificado $^{24}$; o, en fin, en tercer lugar, en algunos casos en los que la víctima del hecho delictivo sea el propio instrumento (y tal hecho no sea penalmente típico, si lo realiza la víctima ${ }^{25}$ sino que lo será solo cuando lo realiza otra persona sobre él ${ }^{26}$ ).

conocido ejemplo de los gansos el criado obra sin ánimo de lucro (o ánimo de apropiación definitiva de la cosa), no realiza ya el tipo de acción del hurto, por más que sepa que los gansos de los que se apodera son de propiedad ajena. De ahí se infiere que no exista problema alguno para calificar como autor mediato al señor (sujeto de atrás) que sí actúa con el ánimo de lucro. Con todo, de esta (tradicionalmente discutida) forma de autoría mediata a través del denominado "elemento doloso sin intención" o "elemento subjetivo egoístamente delimitado" me ocuparé más detenidamente infra IV.4.2.

23 Vid. por todos MIR, P.G., L.14/52: "el funcionario hace destruir a su secretaria particular unos papeles confiados a aquél por razón de su cargo".

24 De esta discutible forma de autoría mediata me ocuparé también infra IV.4.4.

Aquí baste con anticipar que, a mi juicio, la autoría mediata siempre debería ser posible en todos los casos en los que el instrumento no realiza ya el tipo de acción y, por tanto, no puede ser autor en sentido lógico-gramatical. A partir de otra concepción sistemática, algunos penalistas, como MIR (P.G., L.14/58-61), también la admiten, sobre la base de su construcción de la autoría sobre la idea de pertenencia (desarrollada para la autoría mediata especialmente por BOLEA, 2000). De hecho, como bien recuerda DÍAZ G.CONLLEDO (2011, p. 31), el fundamento de la construcción de MIR sobre la autoría basado en la apuntada idea de pertenencia se observa particularmente bien en este supuesto de la llamada autoría mediata por instrumento doloso no cualificado.

25 Vid. por todos MIR, P.G., L. 14/58: p. ej., "A hace tocar a B un cable de alta tensión ocultándole esta circunstancia y produciéndole de esta forma la muerte; B no realiza el tipo objetivo del homicidio ni ningún otro, porque el matarse a sí mismo es atípico".

El procedimiento de instrumentalización más usual será el de la creación o aprovechamiento de un error sobre el significado del comportamiento, al que cabría añadir el caso de la provocación de comportamientos automatizados (cfr. DÍEZ RIPOLLÉS, P.G., p. 367, v.gr., "se interpone un obstáculo 
Ahora bien, salvo en estos tres grupos de casos que se acaban de enumerar, el instrumento también realizará el tipo, concebido como tipo de acción, desde el momento en que comience a ejecutar el hecho típico y ofensivo para un bien penalmente protegido (aunque obre sin dolo ni imprudencia) ${ }^{27}, \mathrm{y}$,

en la calzada, de forma que el conductor, dadas las circunstancias, dará un volantazo automatizado que le resultará necesariamente mortal"), siempre, claro es, que se admita que estos sean considerados como una acción, porque (según indiqué) si el sujeto de atrás no realiza una acción humana (lo que es claro en los supuestos de ataques epilépticos, comportamientos reflejos, comportamientos durante el sueño, fuerza irresistible) no hay instrumento y la autoría de la persona de atrás no sería mediata sino inmediata.

También son imaginables (aunque sean menos frecuentes) los casos de coacción para que otro se autolesione o suicide, en cuyo caso habrá asimismo una autoría mediata. Eso sí habrá de tratarse de una auténtica coacción, provocadora de ausencia de una voluntad libre del instrumento, dado que, de no ser así, estaríamos ante un supuesto de inducción o cooperación a autolesiones (impune) o al suicidio (impune en unos supuestos, pero punible en otros, a tenor del vigente art. 143). Vid. en este sentido DÍAZ G.CONLLEDO, 2001, pp. $34 \mathrm{~s}$.

26 Cabría decir, pues, que la víctima-instrumento no realiza valorativamente (tan solo materialmente) los elementos objetivos del tipo. Cfr. DÍEZ RIPOLLÉS, P.G., p. 367. En el ejemplo descrito en la nota anterior el comportamiento de la víctima daría lugar en el plano objetivo a un suicidio y no a un homicidio.

27 En sentido coincidente vid. DÍAZ G.-CONLLEDO, 1991, pp. 521 ss., admitiendo la posibilidad de que el tipo sea realizado, a la vez (cada uno por entero), por dos sujetos, uno mediato y otro inmediato, a la vista de la diferencia estructural entre autoría mediata e inmediata. En efecto, como bien expone este penalista, en la comprobación de la autoría mediata existen varias fases: en la primera fase, hay que averiguar si concurre el fundamento material que permita afirmar que un sujeto realiza una acción (la que sea) a través de otra persona (desde la perspectiva de la concepción significativa sería la idea de la instrumentalización), cuya acreditación permite explicar ya el presupuesto estructural de la intervención mediata, o sea, que estructuralmente un sujeto actúa a través de otro (por tanto, esta primera fase explica solo una parte del fundamento de la autoría mediata); en la segunda fase hay que comprobar si esa acción que realizan dos sujetos, uno de forma inmediata y otro de forma mediata, coincide de un modo objetivo con la descrita en el tipo correspondiente, esto es, si dicha acción, como proceso puramente objetivo, o fáctico, es capaz de lesionar o poner en peligro directamente el bien jurídico protegido en el tipo, con independencia de si el Derecho, para 


\section{por tanto, el instrumento será también un autor en sentido lógico gramatical $^{28}$, al lado del autor mediato.}

el caso concreto de quien actúa de modo inmediato, considera justificada o disculpada esa acción (o, incluso, si considera que, desde el punto de vista penal, no hay acción); en la tercera fase habrá que comprobar, en su caso, si concurren los elementos personales de la autoría, singularmente, en el supuesto más relevante, el de un delito especial, si en cada sujeto concurre el elemento calificador, un elemento este que, al ser por definición personal, deberá ser acreditado en cada uno de los sujetos de forma independiente.

Por lo demás, y en cualquier caso, conviene insistir en que, desde la perspectiva de la concepción significativa, en esta hipótesis, en la que el instrumento realiza el tipo de acción en sentido fáctico y jurídico, este será, consiguientemente, autor en el sentido lógico-gramatical que aquí nos importa. Finalmente, también coincido con DÍAZ en que, al margen del tema de la autoría (en sentido lógico-gramatical), habrá que considerar después si en cada sujeto concurre la infracción de su norma personal de conducta, en virtud de lo cual será "perfectamente posible que, a quien cumplía los requisitos típicos de la autoría, no pueda castigársele porque, por ejemplo, obró sin dolo o sin dolo ni imprudencia, o justificadamente, pero ello es algo que debe comprobarse independientemente para cada sujeto" (p. 523). Con todo, vid. en la n. 343 las ulteriores observaciones que efectúa este penalista a la disección de las fases estructurales de la autoría mediata.

28 En sentido similar, vid. COBO/VIVES, P.G., p. 749, quienes admiten que el instrumento puede ser también autor, con lo que, consecuentemente, cabría referirse (en este sentido específico) al autor mediato como un "autor detrás del autor"; eso sí con la particularidad de que estos penalistas consideran que si el instrumento obra justificadamente, el único autor sería el autor mediato (particularidad que no comparto desde la perspectiva de la concepción significativa, puesto que, si el instrumento actúa justificadamente, sigue siendo autor en sentido lógico-gramatical, en la medida en que realiza un tipo de acción relevante y ofensivo); vid. además DÍAZ G.-CONLLEDO, 1991, pp. 521 ss. 646 ss. y 690, y 2001, p. 31, coincidiendo -como queda dicho- con la tesis que aquí sostengo en la posibilidad de admitir simultáneamente una autoría mediata y una autoría inmediata del instrumento, pero con la relevante peculiaridad añadida (que personalmente no comparto) de reconocer que este último pueda incluso llegar a ser efectivamente castigado en algunos casos como un autor penalmente responsable del hecho, como sucedería, singularmente, en el caso de que el instrumento obre con imprudencia o en situación de error vencible sobre la prohibición (2001, p. 36). En síntesis, a mi juicio, solo puede admitirse la figura del "autor detrás del autor" en el sentido del concepto lógico-gramatical de autoría, pero no en el sentido apuntado por DÍAZ y por un amplio sector doctrinal (vid. por todos BOLEA, 2000, pp. 158 ss.) de aceptar un autor detrás de otro autor plenamente responsable. 
Por lo demás, desde la perspectiva de la concepción significativa, hay que inferir que en la conducta que realice el instrumento en su condición de autor en sentido lógico-gramatical cabe asimismo una participación punible ${ }^{29}$, aunque después no llegue a ser penalmente responsable del delito.

Y con relación a esto último, hay que tener en cuenta que, a mi juicio, la decisión acerca del contenido de la accesoriedad cualitativa, o sea, la decisión sobre cuál sea el nivel dogmático de implicación en el delito a partir del que quepa hablar ya de un autor y poder admitir el castigo de la participación, nada tiene que ver con la caracterización del instrumento, esto es, nada tiene que ver con la determinación de cuándo una persona puede ser considerada como un instrumento al servicio de otra y, en concreto, a partir de qué nivel dogmático de implicación en el delito puede dejar ya de hablarse de instrumento y, consecuentemente, descartarse la presencia de un autor mediato, que pasaría entonces a ser partícipe en la conducta realizada por el único autor. En síntesis, el concepto de autor en sentido lógicogramatical no prejuzga el concepto de instrumento ${ }^{30}$.

Ciertamente, COBO/VIVES admiten asimismo que el instrumento puede llegar a ser también penado (P.G., p. 749, n. 43), pero esta admisibilidad no se condice con lo que exponen en otro lugar, llegado el momento de caracterizar la figura del instrumento en la autoría mediata: "personas incapaces de comprender el sentido de su acción, sometidas a una violencia absoluta o a amenazas que le sitúan en situación de inexigibilidad o, finalmente, si actúa mediante engaño" (P.G., p. 750), caracterización esta última que también mantiene VIVES en 1996-a, pp. 282 s., según explico más abajo.

29 Obviamente, además del caso anteriormente mencionado (de participación en la conducta realizada por el autor mediato), puede darse el caso de que un partícipe intervenga únicamente en la conducta realizada directamente por el instrumento (desconociendo, a su vez, la existencia de la conducta de un autor mediato).

Por supuesto, si el instrumento no realiza el tipo de acción (y solo el sustrato material del tipo) y, consecuentemente, no es ya autor en sentido lógicogramatical, no cabe la participación en esa conducta. El castigo de la participación tendrá que ir referido entonces exclusivamente a la conducta del autor mediato.

$30 \mathrm{Ni}$ que decir tiene que si, asumiendo los postulados de la concepción significativa, vinculásemos la admisión de la autoría mediata a la inexistencia de 
De otra opinión es un sector doctrinal, que puede verse paradigmáticamente representado en la exposición de DÍEZ RIPOLLÉS ${ }^{31}$, quien, partiendo del principio de la accesoriedad limitada, considera que hay que hablar de autor en cuanto "alguien haya realizado los elementos del tipo en un contexto no justificado, o dicho de otro modo, que la autoría es un problema de injusto" y que ello "repercute necesariamente en la determinación de quién puede ser calificado como instrumento en el marco de la autoría mediata: afirmadas la tipicidad y antijuridicidad del comportamiento del pretendido instrumento respecto al delito en el que asimismo incide la actuación de la persona de atrás, si no queremos entrar en directa contradicción con el contenido y consecuente localización sistemática de la autoría, hemos de afirmar que ese pretendido instrumento no es tal, sino un autor a todos los efectos". Consecuentemente, para DÍEZ, la pérdida de su consi-

autoría (en el sentido lógico-gramatical) en el instrumento, esta institución quedaría indeseablemente restringida a los casos en los que el instrumento no hubiese realizado el tipo de acción (o sea, el denominado tipo objetivo para la opinión dominante), con lo cual quedarían al margen de ella numerosos supuestos de absoluta falta de libertad o de conocimiento de la persona de delante.

Ciertamente, desde la propia concepción significativa, cabría todavía vincular la aceptación de la autoría mediata al ulterior concepto de autor, que incluye la infracción de la norma personal de conducta e incluso la completa ilicitud, esto es, el autor de un ilícito penal, que coincidiría con el concepto de autor de los partidarios del criterio de la accesoriedad limitada (como el mantenido, v. gr., por DÍEZ RIPOLLÉS), pero entonces seguirían quedando al margen de la autoría mediata determinados supuestos en los que la persona de delante obra sin libertad o sin conocimiento de la situación (bien por ser inimputable -si la inimputabilidad se concibe como ausencia de culpabilidad-, por obrar sin conciencia de la ilicitud o por obras en situación de inexigibilidad individual).

Por lo demás, repárese en que en todos estos casos resultaría insatisfactorio político-criminalmente calificar a la persona de atrás como simple partícipe, puesto que, al no admitirse en nuestro Derecho la participación en cadena (vid. por todos MIR, P.G., L.15/28 y 64), surgiría el inconveniente de no poder castigar las conductas de participación en la actividad de una persona de la que materialmente cabe decir que sigue ocupando "el papel fundamental". Vid. infra epígrafe IV.4.1.

31 DÍEZ RIPOLLÉS, 1998, pp. $48 \mathrm{~s}$. 
deración como instrumento comporta necesariamente que la persona de atrás no pueda ser ya calificada como autora mediata, sino como partícipe (o, en su caso, coautora inmediata) en conjunción con la persona originalmente calificada como instrumento.

A mi juicio, ante la opinión de DÍEZ hay que precisar, en primer término, desde la perspectiva que aquí me interesa, que, al delimitar el concepto restrictivo de autor que él asume como punto de partida en función del contenido que asigna al principio de accesoriedad, este penalista abandona el básico concepto lógico-gramatical de autor (incurriendo en la clásica incongruencia -denunciada por VIVES, según señalé más arriba- de los partidarios de una concepción objetivo-formal) para acoger un concepto de autor que incluye no solo la infracción de la norma personal de conducta sino también la ausencia de justificación de la conducta; delimitación que, obviamente, no se comparte en este trabajo. Pero, de otro lado, creo que, en todo caso, hay que poner en tela de juicio la vinculación conceptual automática que DÍEZ establece entre el reconocimiento de la existencia de un autor y la caracterización de lo que sea un instrumento a los efectos de la autoría mediata, de tal modo que la realización de la conducta típica y antijurídica (según él) por parte de una persona comporta ineluctablemente que ya pierda eo ipso su consideración de posible instrumento.

Ciertamente, DÍEZ agrega que, desde su concepción de la autoría, en la autoría mediata el instrumento es tal porque transfiere el control del suceso a esa persona de atrás, de tal manera que "en cuanto se diga del pretendido instrumento que ha realizado el injusto típico se está diciendo que mantiene el control del, además del acceso al, suceso, siendo autor a todos los efectos", en virtud de lo cual, paralelamente, "la persona de atrás pierde el control del suceso, lo que no impide desde luego que realice aportaciones causales, materiales o psíquicas, al hecho, como es propio de la cooperación necesaria, inducción o complicidad, pero en cualquier caso no alcanzará ya la peligrosidad objetiva propia del control de la autoría". En suma, "las hipótesis denominadas de 'autor detrás del autor' en realidad 
deben ser tratadas como supuestos de cooperación necesaria o inducción, y eventualmente de coautoría" ${ }^{2}$.

Ahora bien, frente a esta opinión cabe matizar que, con arreglo al concepto de autor que aquí acojo, la referida "peligrosidad objetiva propia del control de la autoría" no requiere ni la infracción personal de la norma de conducta ni, mucho menos, la actuación en un contexto no justificado, sino simplemente la ejecución de un tipo de acción ofensivo para un bien jurídico penal, por lo que, desde luego, el instrumento (que, a tenor del art. 28 CP, "realiza el hecho por sí solo") lleva a cabo esa ejecución, con independencia de que, a la postre, llegue, o no, a ser responsable del delito; pero también la lleva a cabo la persona de atrás, desde el momento en que comience a utilizar a un instrumento con el fin de realizar el referido tipo de acción (o sea, según el art. $28 \mathrm{CP}$, comience a realizar el hecho "por medio de otro del que se sirve como instrumento").

Por lo demás, lo que antecede no implica desconocer que las observaciones de DÍEZ RIPOLLÉS pueden cobrar su sentido si (aun tomando como punto de partida una perspectiva formal) se asume la idea del dominio del hecho como integrante de la caracterización de la autoría. Ello se comprueba, a mi juicio, cuando DÍEZ cuestiona tesis como la (ya citada) de DÍAZ G.CONLLEDO $^{33}$, sobre la base de entender que esta última "priva

32 DÍEZ RIPOLLÉS, 1998, pp. 49 s.

33 Para este penalista, en materia de autoría mediata hay que diferenciar claramente dos cuestiones: por una parte, la atinente a la constatación de que la persona de atrás actúa a través de otro, lo cual se determinaría básicamente (aunque no de modo exclusivo) merced a la comprobación de si aquella posee el dominio de la voluntad del instrumento, de tal manera que este no actúa libremente; por otra parte, el problema de averiguar si la persona de atrás tiene el dominio objetivo positivo del hecho, un dominio que solo poseería en la medida en que lo tuviese el instrumento, lo cual posibilita por lo demás, que el instrumento llegue a ser castigado en algunos casos (en función de razones alejadas en buena medida de la problemática de la autoría, o sea, cuando la falta de libertad del instrumento verse sobre aspectos que no tengan que ver con el injusto: actuación con dolo y sin que concurran causas de justificación) como autor inmediato, y sin perjuicio de que también lo sea la persona de atrás como autor mediato. Vid. DÍAZ G.-CONLLEDO, 1991, pp. 521 ss. y 646 ss. 
del aspecto de control a la persona de atrás en la autoría mediata" y que "termina por sustituir, en la autoría mediata, a pesar de las apariencias y de posturas más generales en sentido contrario, el aspecto de control por el de acceso", lo cual supone, a juicio de DÍEZ, pasar por alto que "el autor mediato no se limita a acceder al tipo a través del intermediario, sino que, al convertir a este en un mero instrumento personal, pasa él a controlar el suceso en detrimento del control que pudiera ejercer el instrumento. Esto es, a su entender, si la persona de atrás no priva del control al instrumento, éste no es tal", por más que reconozca que ello no cerraría el paso a "hipótesis de control compartido en las que, concurrentes las exigencias de acceso en ambos sujetos, puede darse coautoría" 34 .

De hecho es el propio DÍEZ el que admite explícitamente que es a los defensores de la tesis del dominio del hecho a quie-

34 DÍEZ RIPOLLÉS, 1998, pp. 45 ss. En concreto, objeta DÍEZ (p. 46) que la postura criticada "lleva a que el criterio material de control, que con diferentes concreciones identifica a todas las modalidades de autoría, pierda en la mediata su virtualidad co-fundamentadora del concepto de autor. Ciertamente el dominio del hecho sigue fundando, en su versión de dominio objetivo positivo todas las clases de autoría. Pero en la mediata se predica ante todo del instrumento y no de la persona de atrás; ésta, aunque se dice que posee tal dominio derivadamente, adquiere su peculiar caracterización de injusto a partir de una referencia material que poco tiene que ver con el aspecto de control común a las restantes clases de autoría, a saber, su actuación a través de otro".

Sin ánimo de terciar en esta polémica entre dichos penalistas, me parece que en realidad lo que sucede es que en la caracterización de DÍAZ G.CONLLEDO la idea del dominio del hecho (y, en lo que aquí nos afecta, el dominio de la voluntad del instrumento) se mantiene más bien como una imagen que como un criterio co-fundamentador de la autoría. Como ya señalé anteriormente en diversos lugares, creo que la caracterización de DÍAZ no es siquiera una versión harto heterodoxa del dominio del hecho. Ello se comprueba mejor en sus últimas publicaciones, donde prescinde ya incluso de la terminología del "dominio", a diferencia de lo que hacía en su obra de referencia de 1991, que es la que cita DÍEZ. Y, por lo demás, recuérdese que DÍAZ (al igual que LUZÓN) mantiene (a diferencia de lo que sucede con DÍEZ) un concepto básico de autoría (coincidente con el que aquí sostengo) que es común a delitos dolosos e imprudentes. 
nes una concepción como la de DÍAZ G.-CONLLEDO plantea un grave problema de legitimidad del castigo del autor mediato, puesto que "si su dominio objetivo positivo del hecho, elemento imprescindible y exclusivo para poder ser autor, deriva del que ya posee el instrumento, sin que aquél aporte nada nuevo a tal dominio, ¿qué argumento hay para calificarle como autor? Tal calificación sólo estaría justificada si añadiera al dominio propio de la autoría algún componente que no pudiera aportar el instrumento" $" 35$.

Sin embargo, ni que decir tiene que ningún problema de legitimidad se suscita para quienes descartamos de plano la idea del dominio del hecho para caracterizar la autoría (por tanto, no exigimos este concreto aspecto de control), y simplemente exigimos una equivalencia significativa entre el autor inmediato y el mediato, que no puede ser otra que la (ya repetida) consistente en una utilización del instrumento como si fuese (equivalente a) un animal o una fuerza de la naturaleza, lo que comporta la existencia de un auténtico instrumento y obviamente excluye, por supuesto, un instrumento libre y responsable, aunque esa responsabilidad pueda verse atenuada. Por tanto, en la tesitura de la concepción significativa el único criterio válido para determinar la autoría mediata es (empleando la terminología de DÍEZ) el criterio formal del acceso al tipo, eso sí con la decisiva peculiaridad material de que el autor mediato tiene que realizar/ ejecutar el tipo y, por consiguiente, llevar a cabo una conducta constitutiva de, al menos, tentativa, que, según lo anteriormente indicado, existe cuando la persona de atrás comienza a actuar sobre el instrumento (un sujeto al que se pretende engañar, forzar, intimidar o, en su caso, un sujeto de cuya inimputabilidad se sirve la persona de atrás) pero con la intención de que el instrumento realice de propia mano hasta su consumación un tipo de acción ofensivo para un bien jurídico (o, al menos, la materialidad del tipo, puesto que, como sabemos, en algunos casos el ins-

35 DÍEZ RIPOLLÉS, 1998, p. 47. 
trumento puede no realizar el tipo), una intención que -reitero una vez más- constituye el imprescindible (y único) elemento subjetivo del tipo de acción de la tentativa para cualquier clase de autor, también para el autor mediato.

En otras palabras, y recapitulando, se puede concluir que, desde la caracterización de la autoría aquí asumida, la persona que lleva a cabo la ejecución (que entraña ya, según expliqué, si se quiere, la "peligrosidad objetiva propia del control de la autoría") de un tipo de acción ofensivo para un bien jurídico penal es ya el autor en el básico sentido lógico-gramatical que aquí nos interesa (y que en el art. $28 \mathrm{CP}$ aparece reflejado en la frase inicial "realiza el hecho ..."), sin que, a tales efectos, nos importe todavía dilucidar si ese autor es un instrumento de otro, y sin que nos interese tampoco de momento averiguar, si ha obrado con dolo, con imprudencia o en situación de caso fortuito, si ha obrado al amparo de una causa de justificación o, en su caso, si ha obrado en situación de inculpabilidad.

Por tanto, si es autor en dicho sentido lógico-gramatical, queda abierta, por de pronto, en todo caso la posibilidad de admitir una participación punible en su conducta, con independencia de que, a la postre, dicho autor quede exento de responsabilidad penal, por ausencia de ilicitud o por ausencia de culpabilidad.

Ahora bien, al margen de lo anterior, también es posible que el referido autor sea un mero instrumento al servicio de otra persona que lo utiliza como medio para realizar el tipo de acción; pero en tal caso el instrumento nunca puede perder ya su condición de autor en sentido lógico-gramatical, sin perjuicio de que dicha condición sea compatible con el reconocimiento de la autoría en la persona de atrás, en cuya conducta se puede admitir también, a su vez, una participación punible.

Desde esta perspectiva del concepto lógico-gramatical de autoría, cabe hablar, pues, de un "autor detrás del autor", pero repárese en que esta figura no coincide con aquella que reconoce la opinión dominante, esto es, la de un autor plenamente responsable detrás de otro autor plenamente responsable, cuestión sobre la que volveré más abajo. 
Por lo demás, en fin, y al margen de todo lo que antecede, hay que reiterar, pues, que lo que, en cualquier caso, queda pendiente de determinar, como cuestión ulterior que se plantea de manera totalmente independiente de la anterior, es saber cuándo puede considerarse que la persona que ha realizado inmediatamente el tipo de acción es el "instrumento" que da lugar a una autoría mediata de la persona de atrás (y no a una mera participación). A ello se destina el apartado siguiente.

\subsection{Requisitos que deben concurrir en el instrumento}

3.2.1. Una premisa restrictiva: debe ser irresponsable penalmente

Vaya por delante que la cuestión referente a los requisitos que deben concurrir en el instrumento es una cuestión que, en rigor, queda fuera del objeto central de estudio en la presente investigación, desde el momento en que -como expliqué más arriba- la adopción de los presupuestos que informan la concepción significativa no incide necesariamente en la caracterización de la figura del instrumento.

Con todo, sí hay que dejar constancia de que la acogida del criterio de la accesoriedad mínima objetiva que se deriva de la concepción significativa podrá permitir mantener una (deseable) caracterización restrictiva de la autoría mediata (en sintonía con el concepto restrictivo de autor que aquí propugno), y sin que tal caracterización dé lugar a lagunas de punibilidad.

En concreto, cabrá sostener que solo habrá autoría mediata allí donde la actuación que se ejerce sobre otra persona convierte a esta en un auténtico instrumento ciego de la persona de atrás, o sea, allí donde la persona de delante es utilizada materialmente para llevar a cabo una acción ${ }^{36}$ "de un modo equivalente al empleo de un animal o de una fuerza de la naturaleza" ${ }^{\prime 3}$.

36 Recuérdese, una vez más, que si el instrumento no realiza una acción (un comportamiento humano), la autoría no será mediata sino inmediata o directa.

37 Como ya indiqué más arriba, esta es la idea rectora apuntada por VIVES, 1996-a, p. 282. Tal vez pudiera sostenerse que esta fórmula pergeñada por 
Así las cosas, conviene aclarar de antemano (para evitar malentendidos) que la nota característica de la irresponsabilidad penal del instrumento es simplemente una premisa o condición necesaria para que se pueda llegar a hablar de un instrumento ciego; mas ello no supone todavía una identificación automática entre irresponsabilidad penal del instrumento y aparición de la figura de la autoría mediata. Por tanto, la configuración jurídicodogmática de la autoría mediata no se hace depender exclusivamente de la irresponsabilidad de la persona de delante, dado que -según explicaré después- aquí no se prescindirá de comprobar si existe una verdadera instrumentalización fáctica del ejecutor inmediato. En otras palabras, aquí parto del presupuesto de que es la ausencia de libertad del ejecutor la que constituye el sustrato de la instrumentalización y, por ende, la base sobre la que ha de construirse el concepto de la autoría mediata: de ahí que podrá suceder que la persona de delante resulte ser irresponsable penalmente $\mathrm{y}$, sin embargo, no podamos apreciar una autoría mediata en la persona de atrás que se sirve de ella para ejecutar

\footnotetext{
VIVES debería conducir a rechazar la autoría mediata en los casos en los que simplemente falta el dolo (o, en su caso, imprudencia) en el instrumento $\mathrm{y}$, sobre todo, en los supuestos de que el instrumento actuase al amparo de una causa de justificación, en la medida en que en tales hipótesis el instrumento no obraría como si fuese un animal o una fuerza de la naturaleza. Sin embargo, según esbocé también más arriba, entiendo que cuando VIVES emplea la locución "de un modo equivalente", está obviamente partiendo de la base de otorgar al vocablo equivalente el significado gramatical que recogí anteriormente. Por tanto, hay que sobreentender que la actuación de la persona de delante que realiza un tipo penal pero sin llegar a infringir su norma personal de conducta (obrando, pues, lícitamente), debido a la manipulación llevada a cabo por la persona de atrás, debe ser valorada-desde el desde el punto de vista jurídico- de igual forma que la actuación de quien no realiza un elemento (objetivo) del tipo penal. Es más, una interpretación puramente literal (no valorativa) y estricta de los vocablos "animal" o "fuerza de la naturaleza" para caracterizar al instrumento nos abocaría a una identificación de este con los casos de ausencia de comportamiento humano (dejando fuera incluso los supuestos de ausencia de un elemento objetivo del tipo penal en la actuación de la persona de delante), con lo cual la autoría mediata quedaría completamente vaciada de contenido, dado que -según indiqué- en tales casos la autoría de la persona de atrás sería ya inmediata.
} 
el delito, debido a que no quepa sostener que existe una situación de real carencia de libertad en la persona de delante.

Con lo que acabo de aclarar pretendo eludir objeciones como la que recoge HERNÁNDEZ PLASENCIA cuando critica que el concepto de autoría mediata se haga depender de la irresponsabilidad del sujeto de delante, en lugar de basarlo en la "falta de libertad", lo que conduce a una "excesiva normativización del contenido de la autoría mediata" 38 . Y es que, en efecto, de lo que acabo de exponer se infiere que, de entrada, comparto esta crítica, dirigida a aquellas posiciones que identifican automáticamente irresponsabilidad penal del instrumento y autoría mediata.

Ahora bien, la asunción de esta crítica no comporta tener que renunciar a la característica de la irresponsabilidad penal de la persona de delante como condición necesaria de la figura del instrumento. Y, en este sentido, lo que no puedo compartir es la afirmación del citado penalista de que "la determinación de la falta de libertad es independiente de si el sujeto de delante es o no irresponsable, ya que este dato no prejuzga, ni a favor ni en contra, la autoría mediata" 39 .

Frente a esta afirmación cabe oponer, por de pronto, que la determinación de la falta de libertad no puede en modo alguno ser independiente de la irresponsabilidad penal de la persona de delante, puesto que si esta obra con "falta de libertad" (que, según el Diccionario de la RAE, significa con "carencia o privación de libertad") no puede responder penalmente, en virtud de lo cual la irresponsabilidad penal de la persona de delante tiene que ser, por fuerza, un dato que sí prejuzga la autoría mediata. Cuestión diferente, es que el empleo de la expresión "falta de libertad" no haya sido afortunado y se utilice por dicho penalista en el sentido de "déficit de libertad", pero entonces sucede sencillamente que se está recurriendo a un fundamento diferente, en el que el sustrato de la autoría mediata no es ya la carencia de

38 Cfr. HERNÁNDEZ PLASENCIA, 1996, p. 351, reflejando la opinión de un sector doctrinal.

39 HERNÁNDEZ PLASENCIA, ibid. 
libertad sino un determinado déficit de libertad (en el sentido de una mera afectación a la libertad, sin llegar a anularla), que es el que permitirá aceptar la figura de un instrumento con responsabilidad penal atenuada, algo que es, ciertamente, una posibilidad sustentada por un importante sector doctrinal, pero que aquí no asumo como punto de partida, como paso a razonar.

Así, a mi juicio, habría que descartar, desde luego, la muy amplia concepción de la autoría mediata que se acoge en el art. 14 de la Propuesta de Eurodelitos, conforme a la redacción pergeñada por TIEDEMANN, al contentarse con que el instrumento (la Propuesta emplea este vocablo en la definición general de autoría en su art. 13-1) "carezca total o parcialmente de responsabilidad penal, como consecuencia de un error o por la existencia de una causa de justificación, exculpación o atenuación de la culpabilidad que únicamente a él le afecta" ${ }^{\prime 4}$. Esta concepción desnaturaliza la figura de la autoría mediata y es incompatible con una definición que califique a la persona de delante como "instrumento al servicio de" la persona de atrás ${ }^{41}$, como hace el

40 Vid. TIEDEMANN, 2000, p. 93, quien, a la hora de exponer la fundamentación del precepto, subraya en todo caso el acierto de que "los grupos de casos típicos se mencionaran expresamente" al definir la figura de la autoría mediata, y resalta, en concreto, la previsión de la "posibilidad de punición del autor mediato en el caso de un instrumento que obra conforme a Derecho". En la doctrina española se halla también extendida la opinión de que el instrumento no tiene por qué carecer plenamente de responsabilidad criminal: vid. por todos HERNÁNDEZ PLASENCIA, 1996, pp. 155 ss. y 356; BOLEA, 2000, pp. 159 ss., sobre la base de distinguir entre autoría mediata stricto sensu y autor detrás del autor. Incluso desde la óptica de la concepción significativa, ORTS/G. CUSSAC, P.G., 2017, p. 316, admiten también los casos en los que el instrumento carezca solo parcialmente de responsabilidad criminal, esto es, supuestos en los que el instrumento no queda plenamente exento de responsabilidad, sino solo con una responsabilidad atenuada.

$41 \mathrm{Y}$ es que, en efecto, comparto la (ya apuntada) premisa de que la autoría mediata no se caracteriza tanto por la posición predominante de la persona de atrás como por un déficit personal del intermediario (cfr. PEÑARANDA, 1990, p. 294), a diferencia de quienes, partiendo de la idea del dominio del hecho, consideran que lo relevante es el dominio que posee la persona de atrás sobre la cualidad lesiva de la acción del sujeto de delante (vid. por todos HERNÁNDEZ PLASENCIA, 1996, pp. 211 ss.). 
art. 28 del CP español y que exige también, para el autor mediato, que realice el hecho, del mismo modo que el autor inmediato.

En efecto, según la acepción del Diccionario de la RAE que aquí nos interesa, por instrumento se entiende "la cosa o persona de que alguien se sirve para hacer algo o conseguir un fin". A mi modo de ver, la equiparación de una "persona" con una "cosa" y el empleo del verbo "servirse" (también utilizado en el art. 28 del CP español) $)^{42}$, así como el empleo de la locución prepositiva "por medio de"43, hace que, desde luego, deba ser descartada una caracterización de la autoría mediata que admita una responsabilidad criminal (por muy atenuada que fuere) en el instrumento ${ }^{44}$, por más que un relevante sector doctrinal haya venido sosteniendo

42 Recuérdese que en la acepción pronominal que aquí nos interesa (la $\mathrm{n}^{\circ} 20$ ) "servirse" significa "valerse de una cosa para el uso propio de ella". Por tanto, si ponemos en relación esta definición del verbo "servirse" con la apuntada definición del vocablo "instrumento", llegamos a la conclusión de que, a los efectos de caracterizar una autoría mediata, cuando la persona de atrás utiliza a la persona de delante como un mero instrumento, lo hace como si este fuese una "cosa", lo cual implica, por de pronto, que el instrumento deba ser siempre una persona que (cuando menos) quede exenta de responsabilidad criminal.

43 Según el Diccionario de la RAE, "por medio de" significa "valiéndose de la persona o cosa que se expresa".

44 Coincido, pues, con el sector doctrinal que entiende que la existencia de un ejecutor jurídico-penalmente responsable veda la posibilidad de la autoría mediata, en el sentido de que se considera contradictorio suponer que un sujeto es libre y responsable y, a la vez, un instrumento en manos de otro. En la doctrina española vid. singularmente MIR, P.G., L.14/51, partiendo de la acertada premisa de que en la autoría mediata se produce una inversión de papeles que normalmente corresponden al realizador material y a la persona de atrás, en el sentido de que aquí el papel fundamental, el que permite imputar el hecho a alguien como autor, deja de tenerlo el realizador material para pasar a la persona de atrás, lo cual puede obedecer a dos clases de razones: el realizador material actúa sin libertad o actúa sin conocimiento de la situación, y ello ha sido provocado por la persona de atrás, coaccionando o engañando al instrumento.

De otra opinión es un importante sector doctrinal: vid. por todos ROXIN, A.T., II, $\S 25 / 61$ ss., sobre la base de que "el sujeto de atrás ve o comprende la clase o la magnitud del daño mejor que el autor inmediato"; DÍAZ G.CONLLEDO, 2001, pp. 34 ss., 2007, p. 135, 2017, p. 516. 
que cabe la autoría mediata en casos de error sobre el tipo vencible en el instrumento (o un error sobre los presupuestos objetivos de una causa de exclusión de la ilicitud, si se admite, como creo correcto, la teoría restringida de la culpabilidad) provocado o aprovechado ${ }^{45}$ por el sujeto de atrás, que da lugar a la comisión

Peculiar es la tesis de DÍEZ RIPOLLÉS, quien parte de la (ya referida) premisa de que no cabe hablar de instrumento en el marco de la autoría mediata cuando la conducta de esa persona, pretendidamente instrumentalizada, cumple ya con las correspondientes exigencias de tipicidad y antijuridicidad del delito en cuestión, aun cuando no merezca ser calificada como culpable o punible (1998, pp. 47). Ahora bien con relación a esta afirmación de DÍEZ, hay que llamar la atención acerca del hecho de que, comoquiera que él incluye el dolo en el concepto básico de autoría, cabe la posibilidad de que exista un verdadero instrumento en el caso de que este realice el llamado tipo objetivo, pero no el tipo subjetivo ("y sin perjuicio de que este realice o no los elementos del tipo imprudente"), con lo cual queda expedita la posibilidad de que el instrumento pueda llegar a responder penalmente "si ha realizado una conducta que no observaba el cuidado objetivamente debido - culpa de hecho-" o si "ha actuado en situación de error vencible -culpa jurídica-" (instrumento que quedará, en cambio, sin responsabilidad "si en la conducta peligrosa ha observado el cuidado objetivamente debido, o el error ha resultado invencible"). En fin, DÍEZ admite que en estos casos pueda existir "una autoría mediata en la persona de atrás si controla el suceso" aun cuando el instrumento realice una conducta antijurídica, pero ello obedece a que, para él, el instrumento estaría realizando un "injusto propio distinto" (P.G., pp. 367 s.).

Con todo, desde la perspectiva de la concepción significativa, hay que tener en cuenta-según explico más abajo- que no habrá inconveniente para castigar al sujeto de atrás como partícipe en un delito doloso, pese a que el autor en sentido lógico-gramatical haya realizado un delito imprudente.

45 Comparto la extendida idea (sostenida desde diferentes concepciones sobre la autoría) de que la aceptación de la autoría mediata no debe limitarse a los supuestos en los que el sujeto de atrás crea la situación de error, sino que debe abarcar también los casos en los que se aprovecha de un error preexistente del sujeto de delante para servirse de él y conseguir así que el delito se produzca (vid. por todos ROXIN, A.T., II, § 25/64; CEREZO, P.G., III, p. 215; DÍAZ G.-CONLLEDO, 2001, p. 35; HERNÁNDEZ PLASENCIA, 1996, pp. 176 ss.). Eso sí, la autoría mediata requerirá siempre que el sujeto de atrás lleve a cabo una conducta activa de instrumentalización, o bien una conducta omisiva que fuese exactamente equivalente, según el sentido de la ley, a la activa.

Un sector minoritario considera, empero, que no hay autoría mediata cuando la persona de atrás se limita a aprovecharse del error en el que se encuentra otra persona (aunque aquella sea la única que interviene activamente en 
de un delito imprudente, casos en los que se afirma que el sujeto de delante resulta ser autor inmediato imprudente de un delito y el sujeto de atrás, autor mediato doloso de é él ${ }^{46}$, e incluso que cabe la autoría mediata también en casos en que el instrumento obra

el proceso con conocimiento de su significado lesivo). Vid. en este sentido, p. ej., BOLEA, 2000 , pp. 184 ss., 221 ss. y 250 ss., sobre la base de su caracterización de la autoría como dominio sobre el riesgo.

46 Vid. por todos ROXIN, A.T., II, § $25 / 63$ ss., admitiendo la autoría mediata no solo en casos de imprudencia inconsciente, sino también de imprudencia consciente, con el argumento de que, al confiar en la no realización del peligro, el instrumento que actúa de manera imprudente carece de motivo de inhibición de la realización del hecho (por su peor conocimiento o control), mientras que el aprovechamiento de este déficit fundamenta ya el dominio del hecho del sujeto de atrás, que conoce perfectamente la situación (y por ello "la domina") y se sirve así del sujeto de delante. En la doctrina española vid. por todos DÍAZ G.-CONLLEDO, 2001, pp. 34 s., 2007, p. 135, 2017, p. 516, admitiendo la autoría mediata en caso de instrumento responsable de un delito imprudente, sobre todo en el caso de que la imprudencia sea inconsciente (caso en el que, a su juicio, la situación apenas varía respecto de los supuestos de error invencible, pues el único que "ve" la situación es el sujeto de atrás), pero también la acepta incluso (tras manifestar algunas dudas) en el caso de la imprudencia consciente, aduciendo el referido argumento de ROXIN.

0Sin embargo, frente a esta última argumentación, cabe objetar, desde la perspectiva de la concepción significativa (y del CP español), que lo decisivo a efectos de admitir la autoría mediata no es determinar si el sujeto de delante posee mayores o menores motivos de inhibición (y si el sujeto de atrás "domina" la situación por tener un mejor conocimiento de ella), sino si verdaderamente el sujeto de delante es el instrumento ciego exigido en la ley para que pueda entenderse que la persona de atrás "realiza/ejecuta" el hecho como si lo hubiese efectuado de modo inmediato o directo.

$0 \mathrm{Y}$, más allá de este argumento, cabe oponer en todo caso que, aun cuando la imprudencia fuese inconsciente, nunca podremos afirmar que (atendiendo al significado externo de su conducta) el sujeto de delante (que debería haber conocido los hechos, por más que por su inconsciencia no se los hubiese planteado) obra sin libertad o plenamente engañado por el de atrás. En fin, si renunciamos a planteamientos psicológicos lo decisivo será saber si la conducta del sujeto de delante era, o no, censurable: si lo era, por haber obrado imprudentemente, no hay instrumento y no hay autoría mediata. De hecho, el propio DÍAZ G.-CONLLEDO (2001, p. 34) reconoce que la fundamentación de la autoría mediata que él asume, centrada en el conocimiento en los supuestos de ejecutor inmediato no doloso, ha sido criticada por la doctrina por excesivamente "psicologizante". 


\section{en error vencible sobre la prohibición ${ }^{47}$, admitiendo así en toda su dimensión las hipótesis de autor (responsable) tras el autor (res- ponsable).}

Por lo demás, recuérdese que, según acabo de indicar más arriba, DÍEZ RIPOLLÉS (P.G., p. 368) también admite la posibilidad de autoría mediata en este caso, por la razón allí expresada.

47 Vid. por todos ROXIN, A.T., II, § 25/78 ss., aduciendo, de nuevo, el argumento (inscrito en el pensamiento del dominio del hecho) de que en el error vencible la estructura psicológica de la relación de dominio sería la misma que en el error invencible, eso sí, rechazando la autoría mediata en dos supuestos: cuando el error del ejecutor se debe a una enemistad u hostilidad al Derecho y cuando la persona de atrás no provoca ni la resolución a cometer el hecho ni el error de prohibición del que actúa de manera inmediata. En la doctrina española vid. por todos CEREZO, P.G., III, p. 215, aduciendo el argumento (a mi juicio no compartible) de que "aunque el error fuera vencible, el sujeto ... carece de conciencia de la antijuridicidad"; HERNÁNDEZ PLASENCIA, 1996, pp. 192 ss. y 212, aclarando que en el error vencible "el conocimiento actual del sujeto, el que decide sobre el carácter lesivo de su comportamiento es idéntico" al del error invencible; DÍAZ G.-CONLLEDO, 2007, p. 135, y, anteriormente, su trabajo de 2001, p. 36, donde razona (siguiendo de nuevo a ROXIN) que la persona de atrás "con su exclusivo conocimiento, posee un superior grado de dominio del hecho y, sobre todo, domina o dirige al instrumento".

A mi juicio, frente a la admisibilidad de la autoría mediata en este supuesto, procede reproducir, por de pronto, lo que acabo de indicar en relación con el error sobre el tipo vencible, por lo que no se pueden compartir los argumentos basados en el pensamiento del dominio del hecho y en la idea de que la "estructura psicológica" es idéntica a fuer de entender que quien obra en error vencible carece de un conocimiento "actual" de la lesividad del hecho. Pero, a mayores, cabe añadir que aquí concurre la particularidad de que (asumiendo la dominante teoría de la culpabilidad, que creo correcta y que, en mi opinión, acoge el CP español) el sujeto de delante, pretendido instrumento, es un sujeto que actúa con dolo. Y esta es la razón por la cual un importante sector de la doctrina alemana (así, ya HERZBERG, 1974, p. 374) considera que es de aplicación aquí el principio de responsabilidad que rige para los supuestos de coacción, calificando a la persona de atrás como partícipe. Y esta es, asimismo, la razón por la cual para DÍEZ RIPOLLÉS tampoco cabría la autoría mediata en este supuesto: en efecto, a diferencia del caso del error sobre el tipo vencible, en el caso del error sobre la prohibición vencible el instrumento obra con dolo y no realiza, pues, un injusto distinto. Y téngase en cuenta además que, en todo caso, para este penalista no hay autoría mediata desde el momento en que el instrumento ha realizado ya una conducta típica y antijurídica (aunque el autor no sea, a la postre, 
Ciertamente, si atendemos a la perspectiva político-criminal, podemos comprobar que el recurso a la autoría mediata con el fin de poder castigar como un autor doloso a la persona de atrás que se vale de un sujeto que obra inmediatamente con imprudencia (en situación de error sobre el tipo vencible) adquiere pleno sentido si se acoge la concepción dominante de la accesoriedad subjetiva: en efecto, si en esta tesitura no se admitiese la autoría mediata, llegaríamos a la insatisfactoria conclusión de que la persona de atrás (pese a obrar con dolo de realizar el hecho) tendría que responder como mero partícipe en un delito imprudente. Sin embargo, tal necesidad político-criminal no existe con arreglo a los postulados de la concepción significativa, dado que no hay inconveniente en articular la responsabilidad penal del partícipe (persona de atrás) a partir del delito doloso, aunque el autor haya obrado con imprudencia ${ }^{48}$.

En cambio, esa necesidad político-criminal de acudir a la autoría mediata no concurriría en el caso de que el sujeto de delante hubiese obrado en una situación de error sobre la prohibición, cuando menos para la opinión dominante, que acepta, en materia de error sobre la prohibición, la teoría de la culpabilidad. En efecto, en tal hipótesis la persona de atrás siempre podría ser castigada como partícipe en sentido estricto (inductora, si ha provocado el error, o cooperadora, si se ha aprovechado de un

culpable); de ahí que, incluso en el caso de que la persona de delante hubiese obrado en error invencible sobre la prohibición la autoría mediata no sería factible (P.G., p. 369).

A mayor abundamiento, es menester agregar a lo expuesto que la tesis de admitir la autoría mediata nos conduciría a una evidente inseguridad jurídica (que será mayor o menor en función de los criterios psicológicos que se utilicen para determinar tanto la intensidad de la actuación del sujeto de atrás cuanto el grado de conocimiento potencial del sujeto de delante), como se desprende ya de la decisión del BGH en el conocido "caso del rey de los gatos", en el que, si bien se admite la autoría mediata, se agrega en un obiter dictum que no toda provocación de un error de prohibición vencible fundamentará la autoría mediata. Sobre un entendimiento puramente normativo del error sobre la prohibición vid. MARTÍNEZ-BUJÁN, 2017, p. 72 y n. 125.

48 Vid. MARTÍNEZ-BUJÁN, 2013,pp. 110 ss. 
error preexistente) en el hecho típicamente antijurídico (y doloso) de la persona que actúa de manera inmediata (algo que sucedería incluso en el supuesto de que el error sobre la prohibición hubiese sido invencible $)^{49}$.

En otro orden de cosas, si examinamos la cuestión desde el prisma del CP español, debemos tener presente que en su art. $28 \mathrm{el}$ autor mediato aparece vinculado al mismo verbo rector al que se anuda el autor inmediato y el coautor, esto es, el verbo "realizar" (el hecho) $)^{50}$, lo cual obliga a efectuar una exégesis restrictiva de aquellos supuestos en los que la persona de atrás puede considerarse autora, a pesar de que ella no ejecute inmediatamente o directamente el hecho. Mutatis mutandis ocurre algo similar a lo que sucede en el caso de la comisión por omisión equivalente a la comisión activa, en el que tal equivalencia debe ser concebida de forma restrictiva.

Por consiguiente, en los supuestos reconducibles al grupo de creación o aprovechamiento de un error en el que actúa de manera inmediata, solo será posible admitir la autoría mediata de la persona de atrás cuando la persona de delante resulte ser penalmente irresponsable, por obrar en situación de error invencible (trátese de un error sobre el tipo o de un error sobre la prohibición) o bien por obrar en situación de error sobre el tipo vencible en el caso de que la correspondiente figura de delito no admita la comisión imprudente ${ }^{51}$. Únicamente así, exigiendo que la persona de delante actúe "desconociendo el sentido lesivo de

49 Vid. por todos DÍAZ G.-CONLLEDO, 2001, p. 36.

50 Precisamente, la crítica que se ha venido esgrimiendo en contra del tradicional concepto restrictivo de autor (concebido el sentido riguroso de realización directa de algún elemento típico) es que no permite abarcar los supuestos de autoría mediata (vid. por todos DÍEZ RIPOLLÉS, P.G., p. 358). Sin embargo, el art. $28 \mathrm{CP}$ español nos indica que el autor mediato también realiza (o ejecuta) el hecho. Ello obliga, pues, a mantener el concepto básico de "realización" como característico de toda autoría y, coherentemente, a sustentar un concepto restrictivo de autoría mediata que posea un significado equivalente al de la autoría inmediata o directa.

51 Con relación a estos casos de error vencible sobre el tipo en delitos que no castiguen la forma imprudente de comisión, cobra importancia decisiva el 
lo que hace" ${ }^{\prime 52}$, desde la perspectiva normativa que aquí se preconiza, se cumple la aludida idea rectora restrictiva en materia de autoría mediata.

Por último, al lado de este grupo de casos en los que el instrumento obra en situación de error excluyente de la responsabilidad criminal, hay que incluir también, por supuesto, los casos en los que se ejerce sobre el ejecutor inmediato una violencia o una intimidación (usualmente se emplea el término coacción) que lo coloquen, cuando menos, en una situación de inexigibilidad individual ${ }^{53}$.

Por tanto, para la caracterización del instrumento hay que admitir no solo los casos en los que el ejecutor inmediato obra al amparo de una causa de exclusión de la ilicitud ${ }^{54}$, sino también

tratamiento que se proponga para las discutidas hipótesis de error sobre los presupuestos objetivos de una causa de exclusión de la ilicitud. Si, como creo correcto, este error se califica como un error sobre el tipo (vid. MARTÍNEZ-BUJÁN, 2017, pp. 117 ss.), entonces será factible la autoría mediata de la persona de atrás en las hipótesis de error vencible en delitos que no castiguen la imprudencia, conclusión que no podría sostenerse si tal error fuese calificado como error sobre la prohibición, dado que en esta hipótesis el instrumento habría obrado dolosamente y sería un sujeto penalmente responsable (por más que se tratase de una responsabilidad atenuada). Por lo demás, entiendo que el tratamiento que debe otorgarse al error sobre los presupuestos objetivos de una causa de inexigibilidad es el mismo que debe proponerse para el error sobre los presupuestos objetivos de una causa de exclusión de la ilicitud (vid. MARTÍNEZ-BUJÁN, 2017, pp. 141 ss.).

52 Cfr. VIVES, 1996-a, p. 283.

53 Cfr. VIVES, 1996-a, pp. 282 s., quien, en lo que atañe a la violencia, añade, consecuentemente, entonces que "una vis absoluta convertiría a quien la ejerce en autor inmediato, mientras que una violencia inferior a la descrita lo calificaría de inductor". Como se puede comprobar, VIVES admite, pues, que en caso de ausencia de exigibilidad se da la aludida "equivalencia" valorativa de la actuación del instrumento con "un animal o una fuerza de la naturaleza". La opinión dominante considera también que los casos de vis absoluta son supuestos de autoría inmediata. Vid. por todos BOLEA, 2000, p. 253.

54 En la actualidad, la modalidad de autoría mediata por coacción a través de un instrumento que actúa conforme a Derecho es comúnmente aceptada. Vid. por todos ROXIN, A.T., II, § 25/59; HERNÁNDEZ PLASENCIA, 1996, pp. 154 y 189 ss.; BOLEA, 2000, pp. 257 ss. 
los casos en los que actúa al amparo de una causa de inexigibilidad (estado de necesidad excusante o miedo insuperable) ${ }^{55}$.

En lo que atañe, en concreto, al contenido de la violencia o la intimidación, cabe aclarar que habrá autoría mediata, por supuesto, en los casos en los que la persona de atrás recurre a la coacción ${ }^{56}$ o a otros procedimientos que obligan a actuar al instrumento, esto es, casos en los que dicha persona de atrás fuerza, intimida o da órdenes vinculantes ${ }^{57}$ o coloca en situacio-nes de necesidad de actuar a otro ${ }^{58}$ o aprovecha $^{59}$ una situa-

55 Se coincide así con la opinión dominante, que viene asumiendo el aludido principio de responsabilidad, desarrollado por ROXIN (2000, pp. 143 ss., A.T., II, § 25/48), conforme al cual la coacción fundamentadora de una autoría mediata existe ya cuando se cumplen los requisitos del estado de necesidad disculpante en la conducta del ejecutor.

En efecto, si, a mi juicio, este principio debía ser mantenido ya en los supuestos de error, con mayor razón habrá de ser acogido aquí, en la medida en que el legislador ha determinado ya normativamente la fuerza de la presión psíquica necesaria para eximir de responsabilidad.

56 El término coacción no se emplea aquí en su significado jurídico-penal del art. $172 \mathrm{CP}$, sino en su significado gramatical de "fuerza o violencia que se hace a alguien para obligarlo a que diga o ejecute algo". Por tanto, se incluye la violencia psíquica que actúa sobre la fase de formación de la voluntad y, con ello, la conducta constitutiva de amenazas condicionales. Vid. por todos BOLEA, 2000, p. 255 y n. 7. En la doctrina alemana vid. ROXIN, A.T., II, § 25/47.

57 Vid. por todos CEREZO, P.G., III, p. 216. Los supuestos en los que un sujeto actúa obedeciendo una orden vinculante que no es conforme a Derecho podrían ser calificados de autoría mediata en la medida en que la persona de delante hubiese actuado al amparo de una causa de justificación (supuestos que en la actualidad -suprimida la eximente de obediencia debida- deben ser reconducidos al cumplimiento de un deber -art. 20-7 ${ }^{\circ}$ ). Vid. en este sentido DÍAZ G.-CONLLEDO, 2001, p. 32, calificando estos supuestos de especialmente complejos y necesitados de ulteriores precisiones. Vid. también, con indicaciones adicionales, CEREZO, P.G., II, pp. 227 s. y, especialmente, n. 73; HERNÁNDEZ PLASENCIA, 1996, pp. 191 s.; BOLEA, 2000, pp. 302 ss.; MIR, P.G., L.14/67-69.

58 Por ejemplo, se provoca una situación de legítima defensa para que el agredido se defienda y mate al agresor. Vid. por todos ROXIN, A.T., II, $\S$ 25/51; CEREZO, P.G., III, p. 216. Vid. también DÍEZ RIPOLLÉS, P.G., p. 368 , operando con el ejemplo del instrumento que, en legítima defensa de 
ción ya existente para que realice una determinada conducta ${ }^{60}$. En este grupo de casos el fundamento de la caracterización de un sujeto como instrumento reside en la ausencia de voluntad

extraño, causa graves lesiones a un tercero para defender a la persona de atrás, que ha provocado suficientemente la agresión ilegítima de ese tercero con el fin de que esta sufra daños del instrumento. Vid. además vid. MIR, P.G., L.14/67-69; DÍAZ G.-CONLLEDO, 2001, p. 32. Vid. ampliamente BOLEA, 2000, pp. 261 ss., exponiendo los diversos supuestos y distinguiendo entre situaciones de necesidad que justifican la conducta de la persona de delante, al amparo de la eximente de estado de necesidad (pp. 263 ss.), y supuestos de colocación de un tercero en una situación de legítima defensa (pp. 268 ss.).

59 Vid. por todos DÍAZ G.-CONLLEDO, 2001, p. 32, considerando dudoso ("aunque probablemente también de autoría mediata") el supuesto en el que la persona de atrás aprovecha ("no crea") un estado de necesidad ajeno para sus fines ("te salvo si matas a C") o posibilita el hecho salvador (da una pistola para que, matando a otro, alguien que está en situación de necesidad pueda salvarse). A favor de la autoría mediata, también en este último caso, HERNÁNDEZ PLASENCIA, 1996, p. 166. Con todo, me parece razonable la tesis diferenciadora de ROXIN (A.T., II, § 25/52), restringiendo la autoría mediata a los casos de que se condicione la salvación a la comisión de un hecho delictivo o se proporcione a quien se halle en situación de estado de necesidad la posibilidad -anteriormente inexistente- de salvarse a costa de personas no implicadas (inocentes) en la situación.

60 Con relación a estos supuestos de instrumento que actúa lícitamente (justificadamente) conviene efectuar una importante precisión desde la perspectiva de la concepción que aquí se adopta, a saber, la de que cualquier causa de exclusión de la ilicitud (o de justificación) existente en el instrumento puede permitir la apreciación de la autoría mediata, incluyendo, pues, la legítima defensa y la obediencia debida a órdenes conformes a Derecho. Y ello es así, porque se parte de la premisa de que todas las causas de exclusión de la ilicitud son personales y, por tanto, la apreciación de una de esas causas en el instrumento no puede alcanzar en modo alguno a la persona de atrás. Vid. MARTÍNEZ-BUJÁN, 2013, pp. 79 ss. y 90 ss.

De otra opinión son, coherentemente, aquellos penalistas que no parten de esta premisa y que, además, diferencian entre causas de justificación que excluyen solo el desvalor de acción y causas de justificación que excluyen el desvalor de resultado (como sucede, en este segundo caso, en las mencionadas causas de legítima defensa y la obediencia debida a órdenes conformes a Derecho, en las que la justificación alcanzaría consecuentemente a la persona de atrás, porque no habría resultado injusto). Vid. en este sentido, por todos, DÍAZ, 2001, p. 33, siguiendo la tesis de LUZÓN, P.G., L.21/4 ss. 
libre ${ }^{61}$, fundamento que -según las premisas que aquí adoptodeberá ser interpretado de modo restrictivo, de tal manera que, a mi juicio y a diferencia de lo que entiende un importante sector doctrinal $^{62}$, no existiría el instrumento propio de la autoría mediata cuando la coacción o amenaza no comportase la entidad suficiente para eximir de responsabilidad criminal (sea por ausencia de ilicitud, sea también por ausencia de exigibilidad ${ }^{63}$ ) al ejecutor inmediato, por más que la responsabilidad de este pudiese verse notablemente atenuada, lo que, desde luego, supondría dejar al margen de las hipótesis de autoría mediata casos que se han discutido en la doctrina como el del "jefe o de cerebro de la banda" ${ }^{64} \mathrm{o}$ casos análogos ${ }^{65}$.

61 Vid. por todos indicaciones en DÍAZ G.-CONLLEDO, 2001, p. 32, exponiendo un excelente resumen de los diferentes supuestos concretos. Por supuesto, en el seno de este grupo de casos habría que incluir las hipótesis de utilización de fuerza física absoluta. Lo que sucede es que, como queda dicho, en tales hipótesis la autoría de la persona de atrás será normalmente, a mi juicio, inmediata, y no mediata (DÍAZ, ibid., p. 34 la incluye, en principio, en este grupo, aunque considera opinable su calificación, la cual, por lo demás, reputa -con razón- de nula trascendencia práctica).

62 Recuérdese que para este importante sector basta con que se provoque "un déficit de libertad en el ejecutor material", de tal manera que la persona de delante no siempre resultará exenta de responsabilidad penal. Vid. por todos BOLEA, 2000, p. 261.

63 Recuérdese que en el CP español el grado de coacción requerido para la autoría mediata queda circunscrito a los casos de provocación de un estado de necesidad o de un miedo insuperable en el instrumento.

64 Téngase en cuenta que en las hipótesis genuinas del "jefe de la banda" de delincuentes no existe en rigor ya amenaza o coacción para que se cumplan las órdenes (y ni siquiera existe un aparato organizado de poder, del que me ocuparé en el epígrafe siguiente), puesto que el jefe se limita a organizar el plan delictivo y a dar instrucciones que los miembros de la banda cumplen. Vid. por todos DÍAZ G.-CONLLEDO, 1991, p. 647, y 2001, p. 33, quien se inclina, acertadamente, por calificarlo como inductor o cooperador (normalmente necesario) en el delito que comete otro (u otros) miembro de la banda, aunque exprese alguna dudas, en atención a la especial vinculación entre dicho jefe y los ejecutores inmediatos (mayor que en los casos normales de inducción o cooperación).

65 Algo similar al caso del jefe de la banda cabría predicar de casos análogos enumerados en la doctrina como el de determinadas "ordenes" (sin amenaza 


\subsubsection{El caso de los aparatos organizados de poder (y de las organizaciones empresariales)}

Recapitulando parcialmente, podemos concluir que, de la caracterización del instrumento que se acaba de exponer se infiere ya -en todo caso y cuando menos- que no cabe la autoría mediata si la persona de delante es un autor libre y responsable, con plena visión de la situación fáctica (y jurídica), esto es, que actúa sin déficits de libertad y conocimiento, lo cual sucede señaladamente en el caso de los denominados aparatos organizados de $\operatorname{poder}^{66}$ (y no solo en lo referente a quienes se hallan en la cúspide de la organización, sino también en lo concerniente a los eslabones o mandos intermedios $\left.{ }^{67}\right)$. Y es que, en efecto, hay que compartir la idea-sustentada por un importante sector doctrinal- de que en tal caso el pretendido instrumento es un

ni coacción) de padres a hijos, o el de profesores a alumnos o, en fin, el de algunas relaciones amorosas o de veneración. Vid. en este sentido (y con menos dudas que en el caso del jefe de la banda) DÍAZ G.-CONLLEDO, 1991, p. 648, 2001, p. 33, puesto que, si bien comienza por considerar que son supuestos dudosos, acaba inclinándose por entender que no hay autoría mediata (en general, se tratará de casos de inducción), salvo que "se trate de relaciones de dependencia patológica" (excepción esta que comparto, dado que DÍAZ la sitúa en los estrictos límites de que dicha dependencia comporte una verdadera situación de inimputabilidad en el instrumento).

66 Cfr. DÍAZ G.-CONLLEDO, 2001, pp. 43 s. y 58, 2007, p. 141, quien, con todo, observa acertadamente que estos casos son menos problemáticos, puesto que en ellos será posible con frecuencia el castigo de los sujetos de atrás como inductores o cooperadores en los delitos que los de delante cometen como autores.

La premisa apuntada en el texto supone, pues, mantener la vigencia del denominado "principio de responsabilidad penal", que, a mi juicio, no admite excepciones y que, sin embargo, es abandonado o relativizado por todos aquellos penalistas que admiten la construcción de la autoría mediata a través de aparatos organizados de poder. Vid. por todos indicaciones en BOLEA, 2000, pp. 340 ss.

67 Recuérdese que, según la formulación de ROXIN (y de la mayoría de sus seguidores), la tesis de la autoría mediata (o dominio del hecho) a través de aparatos organizados de poder sería aplicable también a mandos intermedios. Vid. ROXIN, AT II, § 25/106. En la doctrina española vid. especialmente FERNÁNDEZ IBÁÑEZ, 2006, pp. 159 ss., con amplias indicaciones sobre el "dominio escalonado". 
autor inmediato doloso (consciente) y responsable, que realiza el delito merced a una decisión voluntaria libre y que, por tanto, "ve" la situación (en sentido amplio, incluyendo su valoración jurídica) igual que el que da la orden ${ }^{68}$.

En particular, desde la perspectiva de la concepción significativa del delito, me interesa llamar la atención acerca de un equívoco ${ }^{69}$ en el que suelen incurrir los partidarios de la tesis de la autoría mediata cuando asumen la imagen de la persona de atrás como la figura central característica de la autoría, siendo así que, al propio tiempo, reconocen que el ejecutor es también un autor, pese a lo cual otorgan a este un papel secundario ${ }^{70}$. Frente a dicho equívoco hay que oponer con VIVES, por de pronto, algo que ya reflejé más arriba, a saber, que "a la hora de concebir la autoría de uno u otro modo, no se está dilucidando la cuestión sustantiva de a quién cabe atribuir mayor responsabilidad por la realización de un hecho. Desde este punto de vista parece obvio que, en ocasiones, la mayor responsabilidad por un delito puede corresponder, no a quienes lo realizaron, sino a quienes lo proyectaron, alentaron y dirigieron: así lo reconoce expresamente el Código para algunas modalidades de delito; pero, lo que aquí se ventila no es el problema de la relevancia a efectos de la responsabilidad criminal, sino el más limitado, por puramente conceptual de a quién cabe tener por autor"71.

68 Cfr. DÍAZ G.-CONLLEDO, 2001, p. 44 y 2007, p. 137, quien juiciosamente añade que, si admitiésemos la autoría mediata en los casos de aparatos organizados de poder, "quizá también habría que admitirla (pese a las diferencias que sin duda existen con el supuesto analizado) en los casos de quien, disponiendo de ciertas cantidades de dinero, puede contar con encontrar siempre a alguien, en el mundo de la delincuencia habitual o profesional, que cometa acciones delictivas a cambio de una contraprestación económica, sobre todo si se trata de hechos no extremadamente graves" (vid. también 2017, p. 519).

69 Sobre este equívoco, vid., por todos, certeramente DÍAZ G.-CONLLEDO, 2007, p. 138.

70 Esta caracterización estaba ya presente en la primigenia formulación de ROXIN (vid. AT II, § 25/105,107, con indicaciones).

71 VIVES, 1996-a, p. 281. Se hace eco también de esta precisión de VIVES, DÍAZ G.-CONLLEDO (2007, pp. 138 s.), quien, a los efectos de tener en cuenta esa 
Por lo demás, a la vista de la mencionada caracterización restrictiva del instrumento que efectué en el epígrafe anterior, creo que se ve reforzada la idea (sostenida también por la opinión doctrinal española mayoritaria ${ }^{72}$ ) de que en modo alguno puede admitirse una autoría mediata basada en la nota característica de la fungibilidad del instrumento ${ }^{73}$.

Es más, comparto la afirmación de que, incluso a partir de la propia idea del dominio del hecho ${ }^{74}$, la construcción de

mayor responsabilidad, apunta la posibilidad, sugerida por DURÁN SECO, de crear una agravante genérica para los organizadores o similares, con independencia de la calificación de autor o partícipe que reciban en cada caso.

$\mathrm{Y}$, en esta línea de pensamiento, creo que deben ser entendidas todas aquellas modificaciones introducidas en el CP español encaminadas a castigar más severamente a los dirigentes de una organización criminal que a los restante miembros, sea a través del delito autónomo del art. 570 bis, sea a través de las agravaciones especificas introducidas para determinados delitos, como, p. ej., sucede en el art. 369 bis.

72 Esta construcción de la autoría mediata por aparatos organizados de poder ha concitado un amplio rechazo en la doctrina española (vid. por todos, DÍEZ RIPOLLÉS, P.G., p. 370).

73 Vid. por todos, especialmente, la paradigmática y cumplida exposición de DÍAZ G.-CONLLEDO (2007, p. 141, y 2017, pp. 518 ss.), quien (si bien con algunas dudas y por más que la idea de la fungibilidad del instrumento le parezca sugerente) de forma harto clarificadora subraya que, por mucho que entendamos que el sujeto de atrás tiene posibilidades garantizadas por el aparato de realizar sus planes con independencia de la concreta persona del ejecutor, lo cierto es que "si miramos al sujeto concreto de adelante, éste se aparta de la imagen de un 'instrumento' y se acerca a la de un autor inducido por otro que domina plenamente (al menos tanto como cualquier otro autor y probablemente más que algunos) y sin déficits de ninguna clase el hecho", es decir, "el sujeto de delante individualmente considerado es (un autor) idéntico al de los supuestos habituales de inducción (u otra forma de participación). Y totalmente diferente al de los casos más tradicionales y menos discutidos de autoría mediata". Ni que decir tiene que tales reflexiones se ven acentuadas si se observan desde la perspectiva (más restrictiva) que ofrece la concepción significativa en orden a la caracterización del instrumento.

Vid., sin embargo, una defensa del criterio de la fungibilidad del instrumento (elaborado por ROXIN), a partir de la idea del dominio del hecho, en FERNÁNDEZ IBÁÑEZ, 2006, pp. 122 ss., con amplias indicaciones.

74 Sobre la asunción de la autoría mediata en aparatos organizados de poder a partir de la idea del dominio del hecho, vid. vid. especialmente en la doctrina española FERNÁNDEZ IBÁÑEZ, 2006, pp. 7 ss., 122 ss., y passim. 
la autoría mediata por aparatos organizados de poder debe ser rechazada $^{75}$. Con respecto a ello, me parece plenamente acertado el argumento de RENZIKOWSKI, desde la propia tesis del dominio del hecho, consistente en entender que las posibilidades garantizadas de la persona de atrás de ver realizado su plan a través de la organización, con independencia de la concreta persona del ejecutor, no pueden sustituir la efectiva o real ausencia de dominio en el caso concreto (y, por ende, tales posibilidades no son suficientes para fundamentar la autoría) y que no hay figura legal que permita imputar como autor al sujeto de detrás, cuando existe plena autonomía del de delante ${ }^{76}$.

Por otra parte, también en el seno de la vía de recurrir a la autoría mediata, singular mención merece la tesis elaborada por MIR, quien, partiendo de su concepción de la autoría como relación de pertenencia del delito (son autores aquellos causantes del hecho a quienes puede atribuirse la pertenencia, exclusiva o compartida, del delito, porque son los protagonistas o sujetos principales de la realización y ningún otro sujeto se halla en mejor situación para disputárselo), caracteriza la autoría mediata como expresión, lisa y llanamente, de la idea de los distintos ámbitos de competencia en las organizaciones complejas, de tal manera que el hombre de atrás sería siempre autor aun cuando el instrumento hubiese actuado sin error y con libertad respecto de aquel ${ }^{77}$.

75 Vid. por todos CEREZO, P.G., III, p. 217, quien considera, con razón, insuficiente el criterio de la fungibilidad para fundamentar el dominio del hecho. Es más, algún penalista, como HERNÁNDEZ PLASENCIA, 1996, p. 275, llega a afirmar incluso que la fungibilidad "es un argumento que se vuelve en contra de la construcción de la autoría mediata".

76 Cfr. RENZIKOWSKI, 1997, pp. 88 ss. Se hace eco de esta opinión también, compartiéndola, DÍAZ G.-CONLLEDO (2017, p. 519 y 2007, p. 126).

Sobre la insuficiencia del criterio de la fungibilidad del ejecutor para determinar el dominio del hecho, vid. por todos en la doctrina española: HERNÁNDEZ PLASENCIA, 1996, pp. $274 \mathrm{~s}$.

77 Vid. MIR, P.G., L.14/31 y 32 y 58 ss. 
Con todo, frente a esta construcción cabe objetar básicamente, de un lado, que no se compadece bien con un concepto restrictivo de autor, puesto que en realidad la caracterización de la autoría se basa en la mera comprobación de que un sujeto es causante de un hecho, a lo que se añade un vago criterio material como es el de la "pertenencia" del hecho ${ }^{78} ; \mathrm{y}$, de otro lado, cabe argüir que en esta tesis de MIR no queda plenamente esclarecida la cuestión de saber cómo debe responder penalmente ese subordinado que actúa sin error y con libertad respecto a la persona de atrás, y que, en principio, usualmente calificamos de autor inmediato $^{79}$.

Ciertamente, esta última cuestión sí aparece aclarada en la construcción de BOLEA -fundamentada en el pensamiento de MIR- quien, sobre la base de la -más arriba ya apuntadadistinción entre la figura de la autoría mediata en sentido estricto y la figura del "autor tras el autor" que actúan ejecutando las órdenes como los que las dictan desde arriba son autores, a partir de su criterio cimentado en la idea del dominio sobre el riesgo, dominio que, a su juicio, poseen ambos sujetos $^{81}$.

78 Vid. ya críticamente DÍAZ G.-CONLLEDO, 1991, pp. $617 \mathrm{~s}$.

79 Vid. las agudas reflexiones de DÍAZ G.-CONLLEDO, 2001, p. 59, en sintonía con el sector doctrinal mayoritario, que concibe la autoría como dominio del hecho entendido como "control del hecho". Vid. además, desde una perspectiva ortodoxa del dominio del hecho, las observaciones críticas de HERNÁNDEZ PLASENCIA, 1996, pp. 48 s., quien achaca a la postura de MIR una falta de uniformidad.

De hecho, en la última edición de su Manual MIR se limita a asegurar que su fundamentación permite "justificar la autoría mediata en casos en que el instrumento actúa con libertad respecto del hombre de atrás” (L. 14/NM 32), sobre la base de su concepción de la autoría como relación de pertenencia del delito, "que concurre en el sujeto causante al que puede y debe imputársele el delito (el delito, no solo su realización fáctica) como suyo porque ningún otro sujeto se halla en mejor situación para disputárselo" (NM 60). Sin embargo, nada aclara sobre la responsabilidad del instrumento.

80 Vid. BOLEA, 2000, pp. 158 ss. y 168 s.

81 BOLEA, 2000, p. 374; vid. también pp. 394 s. 
Con respecto a esta tesis del "autor (plenamente responsable) detrás del autor (también plenamente responsable)", baste simplemente con recordar que, con arreglo a las premisas de la concepción significativa aquí acogidas, la presencia en el caso concreto de un autor inmediato que realiza/ejecuta el hecho con libertad y sin error veda en todo caso la existencia de una autoría mediata del sujeto de atrás, el cual deberá ser castigado como inductor o cooperador necesario en la conducta del sujeto de delante.

En cualquier caso, con relación a las tesis de MIR y BOLEA, interesa efectuar una ulterior puntualización desde las premisas de la concepción significativa de la acción que aquí acogemos: dichas tesis presuponen reconducir la autoría a la idea de imputación, basando la autoría en la creación, el no control o el aumento de un riesgo de forma objetiva y subjetivamente imputable. Sin embargo, a través de esta vía no se consigue resolver el problema de delimitar quién realiza el hecho como propio, sino que únicamente se aplaza, remitiéndolo a la teoría de la imputación objetiva, de manera que los criterios utilizados en esta teoría se confunden con los criterios empleados para definir el concepto de autor ${ }^{82}$.

En resumidas cuentas, de lo hasta aquí expuesto se infiere que, descartada la figura de la autoría mediata (o construcciones afines como la ya citada del autor tras un autor plenamente responsable, la persona de atrás deberá ser calificada como partícipe en sentido estricto ${ }^{83}$, y, en concreto, como inductor o, en el caso de que no se admita la inducción (p. ej., por no admitirse

82 Cfr. GÓRRIZ, 2008, pp. 399 s. Vid. además, también críticamente sobre la tesis de MIR, a partir de una diferente concepción sistemática: DÍAZ G.-CONLLEDO, 1991, pp. 621 s., quien observa, con razón, que el criterio de MIR no explica demasiado bien por qué los casos de utilización de un instrumento que obra típica y antijurídicamente, pero sin culpabilidad ( o con culpabilidad disminuida) son de autoría mediata; HERNÁNDEZ PLASENCIA, 1996, pp. 48 s., quien objeta que el criterio de MIR quiebra en la autoría mediata.

83 Vid. ya GIMBERNAT, 1966, pp. 187 ss. 
la inducción en cadena y considerar que el único inductor sería el sujeto que dio la orden en la cúpula de la organización, o por considerar que solo sería inductor el último eslabón de la cadena que transmite la orden de ejecutar ${ }^{84}$, como cooperador necesario ${ }^{85}$.

Por otra parte, en el marco de esta denominada autoría mediata a través de aparatos organizados de poder hay que hacer una referencia específica a su posible proyección sobre los delitos cometidos en el marco de una estructura empresarial, puesto que la cuestión se ha planteado en términos parcialmente diferentes.

Con todo, y a fuer de simplificar bastante el tema, lo que, con carácter general, cabe asegurar es que la doctrina española mayoritaria que acepta la construcción de ROXIN sobre esta clase de autoría mediata por "dominio de la organización" se opone, precisamente, a trasladar esta teoría al concreto ámbito de los delitos cometidos en el seno de una empresa ${ }^{86}$.

No obstante, como ha señalado en la doctrina española, entre otros, FARALDO, es preciso efectuar una matización ${ }^{87}$ : en

84 HERNÁNDEZ PLASENCIA, 1996, p. 276, considera que el único inductor es el que transmite la orden de ejecutar, mientras que los miembros intermedios serían cómplices. Para una crítica de la inducción en cadena, vid. por todos FERNÁNDEZ IBÁÑEZ, 2006, pp. 359 ss., con amplias indicaciones.

85 Entiendo que a esta última calificación no puede oponerse la objeción de GIMBERNAT (en lo que concierne a los eslabones intermedios del aparato de poder, calificados también como "ruedecillas", y que él considera como meros cómplices) de que las aportaciones de estos no constituyen un bien escaso, puesto que, antes al contrario, tales ruedecillas poseen carácter esencial para el buen funcionamiento del mecanismo global (DÍAZ G.CONLLEDO, 2007, p. 127 s., 2017, p. 520).

86 Algo señalado ya por el propio ROXIN, AT II, § 25/129 ss.

En la doctrina española vid., entre otros, BOLEA, 2000, pp. 397 ss.; MUÑOZ CONDE, 2001, pp. 208 ss.; MARÍN DE ESPINOSA, 2002, pp. 71 ss.; GALLEGO 2006, pp. 62 ss.; FEIJOO 2007, pp. 166 ss. y 221 s., y 2007-b, pp. 12 ss.; DEMETRIO 2008, p. 65, y 2009, pp. 34 ss.; SILVA 2013-b, p. 54.

87 FARALDO, 2004, pp. 305 ss. Esta matización fue ya apuntada por MURMANN, 1996, pp. 278 s., quien entiende que en el caso de que la empresa 
rigor el único obstáculo relevante estribaría en el argumento de que la aceptación de la autoría mediata con aparatos organizados de poder requiere que el aparato funcione en su globalidad al margen del marco del Ordenamiento jurídico ${ }^{88}$. Por tanto, semejante argumento podría erigirse ciertamente en obstáculo para admitir la autoría mediata por dominio de la organización en los casos en que la empresa comete ocasionalmente algún delito, pero no se opondría a admitirla en los supuestos de empresas cuya finalidad exclusiva o principal es dedicarse a la comisión de delitos $^{89}$. Y, de hecho, en la jurisprudencia del TS se admite prima

tuviese por objeto principal la comisión de delitos se produce una aproximación al supuesto de las organizaciones mafiosas, eso sí, con la particularidad de que, para este penalista, habría una coautoría y no una autoría mediata de la persona de atrás, basándose en que (a diferencia de los aparatos de poder estatales) no existe una relación de confianza del ciudadano hacia él, salvo que el ejecutor material fuese un genuino instrumento (penalmente irresponsable) en manos del dirigente.

Por su parte, PEÑARANDA (2006, p. 424), acogiendo esta idea de MURMANN, se muestra partidario de admitir dicha autoría mediata respecto de organizaciones "formales", esto es, reconocidas por el Ordenamiento jurídico, como sucede paradigmáticamente en el caso del Estado, o como puede suceder también en el caso de organizaciones formales de Derecho privado, mientras no se hayan desvinculado completamente del orden jurídico; en cambio, no sería admisible su extensión a organizaciones mafiosas, porque en ellas "no existe una confianza normativamente fundada en que ese poder (scil., el que poseen los jefes o dirigentes) no se ejerza en perjuicio de los ciudadanos".

88 Sobre este requisito, vid. por todos en la doctrina española FERNÁNDEZ IBÁÑEZ, 2006, pp. 181 ss., con amplias indicaciones, quien, por lo demás, discrepa de ROXIN sobre la necesidad de mantener este requisito; antes al contrario defiende "su no exigencia, con todas las consecuencias que de ahí se derivan" (p. 202).

$89 \mathrm{Y}$, de hecho, así lo ha venido a reconocer un importante sector doctrinal que admite esta clase de autoría mediata a partir de la idea del dominio del hecho. En particular, sobre la autoría mediata basada en el dominio de la organización en el ámbito de la empresa vid. además, singularmente, MEINI, 2008, pp. 182 ss., con ulteriores referencias, llegando a la conclusión de que la idea del dominio de la organización es aplicable en el caso de las empresas medianas y grandes, puesto que la forma en que estas se organizan permite apreciar una instrumentalización del trabajador-ejecutor por parte del directivo. Añade este penalista que a ello no es obstáculo el requisito 
facie la aplicación de la doctrina de los aparatos organizados de poder en el ámbito del Derecho penal económico empresarial, aunque, ciertamente, haya que reconocer que, si se profundiza en el estudio de esta cuestión, se comprueba que en realidad no se está adoptando de forma completa dicha doctrina ${ }^{90}$.

En resumidas cuentas, lo único que aquí pretendo aclarar es que, si somos consecuentes con la genuina formulación de ROXIN, conceptualmente no habría obstáculo insalvable para proyectar su construcción sobre determinados supuestos de estructuras empresariales (por más que -insisto- el propio ROXIN se haya mostrado reacio a dicha proyección $)^{91}$.

Ahora bien, reitero que, si aquí descarto su aplicación en el marco de dichas estructuras, ello obedece a la premisa general sentada más arriba de rechazar ya con carácter general la denominada autoría mediata por aparatos organizados de poder basada en la fungibilidad del instrumento.

Cuestión distinta, específica y peculiar, es la suscitada por DÍAZ G.-CONLLEDO, en referencia singularmente a las mencionadas organizaciones empresariales, a saber, la posibilidad de que la autoría mediata pudiera fundamentarse merced a la suma de diversos factores (que, sin embargo, aisladamente considerados, serían insuficientes): "cierta coacción o algo similar por miedo del ejecutor a perder el puesto de trabajo, visión

de la "fungibilidad" del trabajador, y tampoco lo es el dato de la ajenidad al Derecho por parte del aparato organizado de poder, dado que sostiene que este dato no es un elemento del dominio de la organización (sobre esto último vid. pp. $47 \mathrm{ss}$.).

También GRACIA (2010, p. 93) se ha hecho eco de la posibilidad de recurrir a esta solución en el ámbito de las empresas, pero dejándola abierta.

90 Vid. indicaciones en MIRÓ 2013-b, pp. 333 ss.

$91 \mathrm{Y}$, desde luego, ningún obstáculo existirá ya ab initio para aquellos penalistas que rechazan el requisito de la desvinculación del Derecho, como coherentemente sostiene FERNÁNDEZ IBÁÑEZ, 2006, p. 202, quien considera "perfectamente extensible esta figura a aparatos de poder no desvinculados del Derecho, es decir, que per se no son de naturaleza delictiva" y, en particular, su extensión al ámbito empresarial (p. 197). 
superior o más completa de la situación por el superior, un pequeño grado de fungibilidad, mecanismos de fidelización a la empresa, etc." ${ }^{92}$.

Tal cuestión merecería un estudio detenido (como el propio DÍAZ G.-CONLLEDO sugiere, sin que él tampoco lo haya desarrollado hasta la fecha) pero, a reservas de ese estudio, me inclino a pensar (desde la caracterización del instrumento que aquí he acogido) que si ninguno de esos factores individualmente considerados posee entidad suficiente para eximir de responsabilidad penal al sujeto de delante, no ha lugar a calificarlo de instrumento y, por ende, a admitir una autoría mediata. Todo ello

92 DÍAZ G.-CONLLEDO, 2017, p. 517. El planteamiento de esta cuestión se fundamenta en la idea básica, apuntada ya en otros trabajos anteriores (vid., singularmente, 2001, p. 60, 2007, p. 143), de que "en el ámbito de la delincuencia en estas organizaciones complejas, debe huirse tanto del automatismo de considerar que autor sólo puede ser el último eslabón de la cadena, el operario que actúa inmediatamente (lo cual contradice la propia configuración y principios que rigen esas organizaciones, y frecuentemente aparece como injusto), como del automatismo de creer que no lo será nunca y que la responsabilidad (además a título de autoría siempre) solo haya de recaer en los directores de la organización. Precisamente la complejidad de estas estructuras (que, por cierto, no se configuran exclusivamente por 'los de arriba y los de debajo', sino que en ellas se encuentran multitud de situaciones y posiciones intermedias) obliga a un análisis pormenorizado de los repartos de responsabilidad". Y en estos mismos trabajos ya sugería DÍAZ (ibid.) la aludida posibilidad de que en el seno de aquellas organizaciones cuya "estructura y principios rectores podrían hacer que la existencia de una influencia que no llega a la coacción o de órdenes no estrictamente vinculantes, que por sí sola no fundamenta normalmente una autoría mediata, unida al mejor conocimiento de la situación por el sujeto de atrás (aun sin existir errores de tipo o de prohibición en el sujeto de delante) e incluso el dato de la fungibilidad de quienes actúan delante, sea capaz de fundamentar la autoría mediata en este ámbito". Y, a tal efecto, este penalista recordaba su aceptación de la construcción de un "autor tras el autor", así como que, "quizá, la figura de la coautoría (con algunos matices respecto de los casos más habituales de la misma) o algo que se le parece mucho (que a veces estaría entre el 'autor tras el autor' y la coautoría 'clásica') pude también ser adecuada para la calificación de fenómenos de codelincuencia en este ámbito".

Recuérdese que DÍAZ G.-CONLLEDO (2001, p. 59) rechaza también el traslado de la construcción de ROXIN, relativa a la autoría mediata por aparatos organizados de poder, a la estructura empresarial. 
sin perjuicio de que en determinados supuestos (en los supuestos verdaderamente relevantes) pudiese efectivamente llegar a eximirse de responsabilidad penal al sujeto de delante, sobre la base de considerar que realiza un genuino comportamiento neutral o standard y no infringe su norma personal de conducta, en cuyo caso sí podríamos entender que la persona de atrás es un auténtico autor mediato, $\mathrm{y}$, por supuesto, sin perjuicio de seguir calificando a la persona de delante (ejecutora) como autora en el sentido lógico gramatical, al haber realizado un tipo de acción relevante y ofensivo para un bien jurídico penal.

La conducta de los denominados "empleados subalternos" (conducta dotada de perfiles propios) ha sido objeto de especial atención en materia de delitos económicos, y singularmente en el ámbito de los delitos contra el medio ambiente ${ }^{93}$. Se admite ya usualmente en doctrina y jurisprudencia que la conducta de dichos empleados subalternos, que contribuyen a realizar el hecho típico (v. gr., provocar de modo directo el vertido contaminante), debe quedar al margen de toda responsabilidad penal, siempre que su comportamiento se encuentre por completo fuera de su esfera de competencia y decisión, de tal manera que éstos se limitan a desempeñar su trabajo en términos perfectamente neutros. En otras palabras, se entiende que las conductas "ordinarias" enmarcadas en una relación laboral (que responden a un rol socialmente adecuado, sin excederse de los términos de ese rol), ajustada a la actividad empresarial, no pueden ser penalmente relevantes ${ }^{94}$.

93 En la doctrina alemana vid. por todos ya MURMANN, 1996, pp. 279 s., si bien este penalista considera que la exclusión de la responsabilidad penal del ejecutor material solo existirá en casos excepcionales o en conductas imprudentes, pero no como regla general en las conductas dolosas, en atención a lo cual el ejecutor material sería autor y el superior que da la orden, inductor, al no poseer el dominio del hecho (salvo que estuviese especialmente obligado en sentido jurídico frente a terceros a no favorecer delitos de sus subordinados).

94 Vid. ya SILVA, 1999, p. 37, citando en este sentido la SAP Barcelona de 13-6-1995 y razonando que dicha fundamentación es la que puede explicar 
Eso sí, se trata de una cuestión que nos remite ineludiblemente al caso concreto para estar en condiciones de determinar en qué supuestos podemos concluir que existe tal comportamiento neutral o standard, cuestión verdaderamente compleja y controvertida en la doctrina, que se vincula necesariamente al fenómeno de la delegación de competencias, que modernamente ha comenzado a ser objeto de especial atención en la doctrina española ${ }^{95}$.

satisfactoriamente la exoneración de los empleados subalternos, en cuyos comportamientos no siempre será posible recurrir a la teoría del error o a invocar una situación de inexigibilidad.

En sentido análogo, pero con una posición más matizada, vid. MUÑOZ LORENTE, 2000, $\mathrm{n}^{\circ}$ 22, (comentario a la SAP Pontevedra 13-3-2000) pp. 43 ss., quien, tras asumir en principio la fundamentación antecitada en referencia a los empleados subalternos, apunta, empero, que en muchos casos el autor material de los vertidos es plenamente consciente de estar realizando un atentado al medio ambiente y la posible obediencia que debe a sus superiores no puede llegar al extremo de realizar conscientemente un delito y quedar exento de pena, por mucho que la decisión de realizar vertidos -esto es, de cometer el delito- se encuentre fuera de su esfera de competencia y él se haya limitado única y exclusivamente a cumplir órdenes (pp. 44 s.). Y, efectivamente, esta matización debe ser asumida, exigiendo la responsabilidad penal del empleado, pero siempre que este se aparte de su estándar normativo o posición jurídica predeterminada para adaptar su comportamiento o reorganizar su esfera de actividad a un hecho delictivo (vid. MONTANER 2008, pp. 102 s.). Por lo demás, vid. más ampliamente lo expuesto en MARTÍNEZ-BUJÁN, P.G., en el epígrafe V.5.4., al examinar la cuestión de la obediencia debida del trabajador a las órdenes del empresario, y en el epígrafe. 7.5.3., sobre las "conductas neutras o neutrales").

95 En este sentido cabe destacar la contribución de MONTANER (2008, passim, especialmente pp. 86 ss. y 99 ss.), elaborada sobre la base de distinguir dos tipos fundamentales de delegación. Por una parte, una delegación de competencias en sentido estricto o propio, que es la que se establece entre los niveles de la dirección, eso sí, excluyendo los supuestos de "asignación de ámbitos de competencia" (que son los propios de la relación entre el empresario o administrador y sus directivos funcionales, como, v. gr., el director de producción de la empresa), supuestos en los que no existe un verdadero traspaso de competencia, sino una mera configuración formal de la estructura personal de la empresa.

Por otra parte, una delegación (en sentido impropio) consistente en el mero "encargo de la ejecución de una función" (característica de la relación entre 
Por tanto, y resumiendo, el caso de los empleados subalternos que actúan de un modo plenamente neutral o standard (siguiendo las instrucciones enmarcadas en su rol profesional) comportará, a mi juicio, la consecuencia de otorgar a la persona de delante, que obra inmediatamente, la consideración de un verdadero instrumento, que es plenamente equiparable a las restantes hipótesis de instrumentalización anteriormente expuestas, con lo cual podrá calificarse, consiguientemente, de autor mediato al sujeto de atrás que, en el marco de la estructura empresarial jerárquica, adopta la decisión delictiva.

directivos y empleados sin autonomía decisoria), en cuyo caso la atribución de la responsabilidad penal será diferente a la fijada para los casos de delegación en sentido propio, según que el encargo sea, o no, en origen delictivo: en el primer supuesto, el que realiza el encargo será autor, mientras que el encargado podrá ser partícipe siempre que su aportación se aparte de la conducta estándar o neutral; en el segundo supuesto el encargado responderá penalmente si, después de haber asumido correctamente el encargo, infringe los deberes que le vinculan, sea como autor sea como partícipe, en función de la concreta actividad realizada, actividad de la que, por supuesto, podrá responder también el mandante si él, a su vez, infringe su norma de conducta con posterioridad al encargo (sobre esto último vid. pp. 104 s.).

Por último, habitualmente se afirma en la doctrina y en la jurisprudencia que, para que despliegue los efectos que normalmente se le atribuyen, la delegación habrá de ser "válida" o "lícita", entendiéndose por tal aquella que cumple una serie de requisitos (cuya concreción es controvertida), entre los que suelen citarse: que se realice a favor de una persona idónea, que esta disponga de un amplio ámbito de autonomía y que la delegación se conceda formalmente por escrito con indicación específica de las funciones delegadas (vid. por todos indicaciones en MONTANER 2008, pp. 107 ss.). Ello no obstante, como escribe esta penalista, dicha afirmación debe ser matizada en el sentido de que la invalidez de la delegación no tiene por qué comportar automáticamente su ineficacia absoluta, habida cuenta que hay que atender a cuál haya sido la causa de invalidez de la delegación (pp. 109 ss.). Si la causa es la inidoneidad ex ante del delegado, se bloquea ciertamente el efecto normal de la transformación de las esferas de competencia, pero el delegado inidóneo que asume el encargo crea una situación de peligro de la que podrá ser responsable por injerencia; asimismo, se suele distinguir entre una inidoneidad absoluta, que impide la eficacia de la delegación, y una relativa, en la que el delegado que asume el encargo puede verse como un delegado de hecho. Si la causa de la invalidez es la falta de autonomía o dominio del delegado, estaremos normalmente ante un caso de delegación defectuosa 
Con arreglo a las premisas de las que aquí parto, en el caso en comentario el empleado subalterno obraría en la mayoría de los supuestos al amparo de un riesgo subjetivamente permitido, que -según expuse más arriba- excluye la infracción del deber objetivo-subjetivo de cuidado y que, por tanto, posee la función de excluir la ilicitud personal del comportamiento realizado por un sujeto (que es autor en sentido lógico-gramatical), pese a haber realizado un tipo de acción relevante y ofensivo, infractor del deber objetivo-general. Todo ello, sin perjuicio de que, en la práctica, en algunos casos pudieran quedar excluidos el dolo o la imprudencia, aunque aquí la autoría mediata se fundamentaría, obviamente, en la presencia de un error en el instrumento ${ }^{96}$.

Por lo demás, simplemente quisiera dejar constancia aquí de que si no se admitiese la construcción de la autoría mediata en el caso de los comportamientos neutrales o standard, siempre resultará factible recurrir a la vía de la comisión por omi-

sobrevenida: por tanto, habrá que diferenciar según se trate de una delegación de competencias en sentido propio, en la que el delegado ya se habrá convertido en el principal responsable de las consecuencias que se deriven del ámbito delegado (por lo que si continúa su actividad sin disponer de los medios necesarios responderá, por lo general, de los resultados lesivos que de ahí se deriven) o bien se trate de una delegación de la ejecución de una función, en la que el delegante continuará siendo el principal responsable (por lo que si el encargado, tras haber requerido infructuosamente al delegante en procura de los medios necesarios, continúa realizando su función conforme a los parámetros que lo vinculan, no será responsable de las consecuencias lesivas que se deriven). Por lo demás, en cuanto al requisito de la forma escrita, hay que convenir en que a los efectos jurídico-penales lo decisivo es la perspectiva material, por lo que la ausencia de forma escrita no impide que la delegación tenga eficacia.

En la más reciente doctrina se continúa profundizando en el estudio del fenómeno de la delegación ante las numerosas situaciones problemáticas adicionales, como p. ej., la figura del delegado sin medios, la del subordinado dominante en virtud del control de los flujos de información o la del delegado de vigilancia (cfr. SILVA 2013-b, p. 57).

96 Sobre las conductas neutrales en el ámbito empresarial, vid. MARTÍNEZBUJÁN, P.G., 5ª d., 2016, pp. 629 ss. 
sión para castigar al directivo, sea a título de autoría sea a título de participación (solución esta última que me parece preferible para determinar la responsabilidad penal en el ámbito de las estructuras empresariales ${ }^{97}$ ).

\subsubsection{Los casos de inimputabilidad}

Antes de entrar a analizar estos casos hay que tener en cuenta que (a diferencia de la opinión dominante) aquí parto de la base de que la imputabilidad no es un elemento perteneciente a la culpabilidad, sino que debe ser incluido en el ámbito de la segunda categoría del delito, la ilicitud, y debe ser examinado con carácter previo a las formas de ilicitud, dolo e imprudencia.

Eso sí, aun cuando se asuma esta posición como punto de partida, entiendo que en algunos casos calificados legalmente

97 Vid. MARTÍNEZ-BUJÁN, P.G., pp. 524 ss., con amplias indicaciones, en la línea emprendida en la doctrina alemana por SCHÜNEMANN. A ellas hay que añadir el trabajo de DÍAZ G.-CONLLEDO, 2007, pp. 143 s., donde, tras analizar la vía de la autoría mediata y reconocer la complejidad del fenómeno, esboza también la solución de la comisión por omisión, eso sí, matizando (matización que obviamente comparto) que no es suficiente para imputar delitos en comisión por omisión al titular del órgano directivo que éste tenga un deber de control, sino que se han de añadir datos (actuación del ejecutor para la empresa, especificidad del deber, sobre todo relación de equivalencia, etc.) que permitan tal imputación, más complicada cuanto más estricto se sea en los requisitos de la comisión por omisión. Por lo demás, se hace eco también, acertadamente DÍAZ, de la creación de tipos de omisión pura o híbridos para supuestos de desatención de los deberes de vigilancia y control de quienes ocupan ciertas posiciones en la empresa.

Sobre esta particular cuestión vid. MARTÍNEZ-BUJÁN, 2015, pp. 104 ss., donde se contienen unas propuestas de lege ferenda al hilo del comentario crítico que se efectúa al artículo 286 seis del Proyecto de Ley Orgánica de Código penal español de 2013. Ciertamente, dicho precepto no puede ser tomado como modelo para una futura regulación, puesto que se trataba de una norma muy deficiente, merecedora de crítica por diferentes motivos; ello no obstante, partiendo de la base de que no sería descartable introducir un precepto genérico de estas características, se incluyen unas propuestas que deben ser entendidas con independencia de las que quepa adoptar con respecto a la posible creación de una cláusula genérica de atenuación para omisiones de gravedad intermedia (que no lleguen a ser comisión por omisión) en el art. $11 \mathrm{CP}$. 
de inimputabilidad en nuestro $\mathrm{CP}$ habría que rechazar la autoría mediata, si se comparte (como creo que debe hacerse) la ya apuntada idea rectora de entender que solo habrá autoría mediata cuando la actuación que se ejerce sobre otra persona convierte a esta en un puro instrumento ciego del autor, o sea, allí donde la persona de delante es utilizada como tal, pero de modo equivalente al empleo de un animal o de una fuerza de la naturaleza. Y es que, en efecto, aceptada esta idea rectora, habrá que convenir entonces con VIVES en que solo cabrá hablar de autoría mediata cuando se actúe sobre personas incapaces de comprender del todo el sentido de la acción de la conducta (no meramente inimputables) $)^{98}$.

Pues bien, asumiendo esta premisa rectora, creo que, en lo que concierne a la imputabilidad, debe compartirse la matización efectuada por otros penalistas, que, aceptando que lo que permite hablar de verdadera instrumentalización del ejecutor inmediato por parte de la persona de atrás es la incapacidad o anormal capacidad de comprender la ilicitud del hecho o de motivarse según esa comprensión del sujeto (inimputable) que actúa inmediatamente (comprensión o capacidad de motivación que no le falta al sujeto de atrás), introducen la salvedad de que en algunos casos de inimputabilidad legal reconocida en el vigente CP (como acontece singularmente en la menor edad) ${ }^{99}$, no

98 Este es el criterio específico que propone VIVES (1996-a, p. 282) para los supuestos de inimputabilidad, partiendo de la referida idea rectora en materia de autoría mediata.

99 Especialmente contundentes se han pronunciado algunos penalistas, como SILVA (1997, pp. 173 s.), quien, en referencia ya al vigente CP español, ha propuesto "desvincular la exención de responsabilidad criminal convencional en el caso del menor de la noción clásica de inimputabilidad", sobre la base de abandonar el denominado "modelo del discernimiento" y consecuentemente diferenciar entre los sujetos que padecen anomalías o alteraciones psíquicas, de un lado, y los menores de edad, de otro, una diferencia que se apoya en los distintos presupuestos de cada exención (en los primeros, la incapacidad de comprensión de la ilicitud del hecho o de actuar conforme a esa comprensión -algo que no cabe predicar de los menores de edad- o, para la opinión más moderna, la falta de necesidad preventi- 
deja de ser una ficción hablar de instrumentalización de un ser humano o de incapacidad de comprensión o motivación ${ }^{100}$. Dicho de otro modo, el concepto de inimputabilidad legal, que rige para eximir de responsabilidad criminal al ejecutor inmediato que se halla incluido en alguna de las causas legalmente defini-

va de pena; en los segundos, la falta de necesidad preventiva de la pena convencional imponible a los adultos) y que se apoya también en la propia distinción que fija el legislador al regular de forma separada los supuestos de menor edad (art. 19) y los restantes de inimputabilidad (art. $20,1^{\circ}, 2^{\circ}$ y $3^{\circ}$ ). En fin, como señala SILVA en p. 159, el menor de 18 años no es un sujeto per se, o esencialmente, inimputable, sino que simplemente "no es responsable criminalmente" conforme a las disposiciones del CP de los adultos: en otras palabras, es un sujeto responsable (como, por cierto, proclama explícitamente el párrafo $2^{\circ}$ del art. 19), al que, sin embargo, por obvias razones político-criminales se le sustrae del ámbito de las consecuencias jurídicas comunes del CP.

La defensa de la autoría mediata por parte de algunos penalistas como ROXIN (AT II, § 25/143) se basa en argumentos, a mi juicio, no compartibles (al menos en el Derecho español), como el de afirmar que también existe un resto de culpabilidad en el ejecutor de un hecho en estado de necesidad disculpante o el argumento político-criminal de no implicar al menor en el proceso penal.

100 Cfr. DÍAZ G.-CONLLEDO, 2001, p. 41, quien alude al ejemplo de quien induce a un muchacho de diecisiete años a realizar un delito de daños. Y es que, efectivamente, desde la perspectiva del CP español cabría añadir que el ser menor de dieciocho años no comporta necesariamente que "no pueda comprender la ilicitud del hecho o actuar conforme a esa comprensión" (requisito exigido en las eximentes de los números $1^{\circ}$ y $2^{\circ}$ del art. 20) o que "tenga alterada gravemente la conciencia de la realidad" (requisito exigido en la eximentes del $n^{\circ} 3^{\circ}$ del art. 20).

Es más, cabría incluso poner en tela de juicio que pueda surgir automáticamente la autoría mediata cuando se utilice a una persona menor de catorce años (límite de la imputabilidad en la Ley de responsabilidad penal del menor). Vid. en este sentido CEREZO, P.G., III, p. 216, invocando el argumento -coincidente con el que aquí se preconiza- de que el criterio decisivo para afirmar la autoría mediata será "su capacidad de comprender el carácter ilícito de su conducta y de obrar conforme a esa comprensión".

Por tanto, la autoría mediata solo surgiría cuando el menor no hubiese alcanzado "el mínimo de madurez psicológica", dado que en ese caso sería -como indica SILVA (1997, p. 160)- un sujeto plenamente irresponsable en sentido estricto. Vid. también en sentido similar, GÓMEZ RIVERO, 1995, pp. 255 s.; BOLEA, 2000, p. 334. 
das en el CP, no tiene por qué ser trasladado automáticamente a la caracterización de la autoría mediata con el fin de determinar si el sujeto de atrás, que se vale del inimputable, es un verdadero autor mediato o solo un partícipe, puesto que lo decisivo no puede ser el concepto legal formal de inimputabilidad (que puede basarse en una presunción iuris et de iure, como sucede en el caso de la menor edad), sino un concepto material, asentado en una situación real de inimputabilidad, conforme a la fundamentación anteriormente expuesta ${ }^{101}$.

Sí existirá en todo caso autoría mediata cuando la persona utilizada se halla en alguna de las situaciones descritas en los números 1, 2 y 3 del art. $20 \mathrm{CP}$, en la medida en que estas presuponen una plena incapacidad para comprender el sentido de la acción de la conducta, siempre que, obviamente, la persona de atrás provoque dicha situación de inimputabilidad o se aproveche conscientemente de ella ${ }^{102}$.

Ahora bien, téngase en cuenta que, según los postulados que aquí acojo, la circunstancia de que la persona de delante sea completamente incapaz de comprender el significado de su acción no impedirá que esta puede llegar a ser autor en el sentido lógico-gramatical (siempre que realice un tipo de acción relevante y ofensivo, y no meramente el sustrato material del tipo) y que en la conducta que realice en su condición de instrumento

101 Cfr. DÍAZ G.-CONLLEDO, 2001, p. 42.

102 A mi juicio, al igual que sucedía con las hipótesis de error, debe bastar con que la persona de atrás se aproveche conscientemente de la situación de inimputabilidad de la persona de delante, sin que, por tanto, sea necesario que esta deba haber provocado previamente dicha situación. En este sentido se pronuncia la doctrina mayoritaria, vid. por todos CEREZO, P.G., III, p. 216. De otra opinión es un sector doctrinal: vid., p. ej., BOLEA, 2000, pp. 331 ss., restringiendo la autoría mediata a los casos en que la persona de atrás provoca la situación de inimputabilidad y se aprovecha después de ella, con lo que (al no admitir tampoco los casos de inimputabilidad parcial) la figura de la autoría mediata a través de un inimputable únicamente se admitiría "de modo excepcional"; en sentido próximo GÓMEZ RIVERO, 1995 , p. 245. 
cabrá asimismo una participación punible, aunque él no sea penalmente responsable del delito.

Por lo demás, en consonancia con la aludida idea rectora de la que aquí parto, a saber la de que el instrumento debe venir caracterizado por tratarse de personas incapaces de comprender del todo el sentido de la acción de la conducta ${ }^{103}$, habrá que entender que no cabrá la autoría mediata en los casos en que la persona de atrás induzca a semiimputables (señaladamente a jóvenes de determinada edad) a la comisión de delitos ${ }^{104}$.

Finalmente, téngase en cuenta que, aunque aquí he partido de la premisa de que la inimputabilidad debe situarse en el seno de la pretensión de ilicitud, antes de la categoría de la culpabilidad, no habrá problema alguno para calificar como partícipe a la persona de atrás aun cuando la persona de delante no posea la característica de auténtico instrumento (v. gr., por tratarse de un menor de 18 años), siempre que esta persona lleve a cabo un hecho típicamente relevante y ofensivo para un bien jurídico-penal, habida cuenta de que la realización de este hecho resulta ya suficiente para poder asociar a él una participación

103 Obviamente ni que decir tiene que dicha incapacidad de comprensión debe ir referida al concreto delito cometido, dado que es fácilmente imaginable que una persona que padezca un retraso mental sea capaz de comprender. V. gr., lo injusto de un homicidio pero no el de un delito económico (sobre esta cuestión vid. ROXIN AT II, § 25/141). Así, a mi juicio, sucede simplemente que en el caso del delito económico será inimputable y en el del homicidio obrará, como mucho, en estado de semi-imputabilidad.

104 Rechazando los casos de inimputabilidad parcial, vid. por todos, con indicaciones, BOLEA, 2000, pp. 331 s. En cambio, DÍAZ G.-CONLLEDO (2001, p. 42), en congruencia con su planteamiento general de admitir la autoría mediata en supuestos de responsabilidad criminal atenuada del instrumento, deja abierta la posibilidad de aceptar la autoría mediata, añadiendo que el problema es muy complejo. A su juicio, y de modo similar a lo que sucede en los mencionados casos del menor de edad de 17 años, la calificación del sujeto de atrás dependería de la incidencia real, material, en cada caso, de la semiimputabilidad en la capacidad de comprensión de la ilicitud del hecho y de motivación (o inhibición) conforme a ella del propio semiimputable (algo que el CP requiere ya expresamente en otros supuestos de inimputabilidad, como en los números $1^{\circ}$ y $2^{\circ}$ del art. 20). 
punible, de conformidad con el criterio de la accesoriedad mínima objetiva.

\subsubsection{Los casos de ausencia de culpabilidad}

De lo expuesto en apartado anteriores cabe inferir ya que si la persona de delante obra sin culpabilidad, no cabe rechazar la autoría mediata, sin que sea obstáculo a ello el hecho de que el instrumento realice una conducta típica y antijurídica, habida cuenta de que-como queda dicho- lo único decisivo de cara a la admisión de la autoría mediata debe ser el dato de que el ejecutor inmediato actúe sin conocimiento de la situación o sin libertad. Por tanto, desplazada la imputabilidad a la categoría de la ilicitud, cabe concluir que, en el seno de este apartado referente a la culpabilidad, será factible admitir una autoría mediata en casos en que el instrumento se halle en situación de error invencible sobre la prohibición o en situación de inexigibilidad.

En consecuencia, con arreglo a las premisas que aquí he asumido, conviene aclarar que no se comparten dos tesis que se inscriben en polos opuestos: de un lado, la tesis de que la realización de una conducta típica y antijurídica (personalmente ilícita) por parte de la persona de delante elimine ya toda posibilidad de aceptar la presencia de un instrumento fundamentador de una autoría mediata; de otro lado, la tesis de que la realización de una conducta por parte de la persona de delante en una situación de culpabilidad disminuida (o sea, sin exención plena de responsabilidad) pueda dar lugar a la caracterización de dicho instrumento $\mathrm{y}$, por ende, a una autoría mediata de la persona de atrás.

De la primera de dichas tesis ya me ocupé más arriba al caracterizar la figura del instrumento con base en la noción de autor que se deriva de la concepción significativa de la acción y analizar aquellas posiciones doctrinales que -como la de DÍEZ RIPOLLÉS- rechazan que pueda ser calificado como instrumento aquella persona que ha realizado una conducta típica y antijurídica, a fuer de delimitar el concepto de autor en 
función del contenido que se asigne al principio de accesoriedad (limitada) ${ }^{105}$.

Aquí simplemente procede agregar, desde la perspectiva político-criminal, que, ciertamente, el recurso a la figura de la autoría mediata no resulta, en principio, necesario para colmar lagunas de punibilidad, dado que a la persona de atrás siempre se la podrá castigar como partícipe en la conducta típica y antijurídica que lleva a cabo la persona de delante; y que esta apreciación, que rige para la opinión dominante (partidaria del criterio de la accesoriedad limitada), con mayor motivo debe ser acogida desde la óptica de la concepción significativa, que, como sabemos, comporta asumir el criterio de la accesoriedad mínima objetiva.

Ahora bien, pese a ello, un amplio sector doctrinal (que, además, incluye la imputabilidad en la culpabilidad), se inclina por considerar preferible la atribución del papel de autor a la persona de atrás ("sobre todo cuando éste ha provocado intencionalmente" la posición de inculpabilidad), en la medida en que el ejecutor se halla en una posición subordinada ${ }^{106}$.

105 Vid. supra 3.2.1., donde expuse las razones que me mueven a descartar esta tesis, que comporta un abandono del básico concepto lógico-gramatical de autor y una vinculación conceptual automática entre el reconocimiento de la existencia de un autor y la caracterización de lo que sea un instrumento a los efectos de la autoría mediata.

En este lugar simplemente debo añadir que, llegado el momento de caracterizar la autoría mediata, los partidarios de esta tesis (y, en concreto, DÍEZ RIPOLLÉS, P.G., p. 369) excluyen de la autoría mediata, coherentemente, todos los supuestos en los que la persona de delante obra en situación de inculpabilidad.

106 En la doctrina española vid. en este sentido, por todos, la ya apuntada opinión de MIR, P.G., L.14/70 s., a pesar de reconocer que, a partir del criterio de la accesoriedad limitada, la figura de la autoría mediata no sería necesaria a los efectos de castigar a la persona de atrás (que sería considerada como inductora del hecho antijurídico realizado sin vulnerar el principio de accesoriedad de la participación). Ello no obstante, repárese en que MIR no se apoya aquí en su criterio de la pertenencia, sino más bien en la idea de la subordinación o de la esencialidad de la conducta del autor frente a la del partícipe (cfr. DÍAZ G.-CONLLEDO, 1991, p. 622). 
Y con relación a esta opinión es preciso recordar cabría, una vez más, que no es lo mismo que la persona de atrás sea calificada como partícipe que lo sea como auténtico autor mediato, habida cuenta de que en esta segunda hipótesis se abre la posibilidad de admitir la participación (señaladamente la inducción) de terceras personas en la propia conducta de la persona de atrás que actúa como auténtico autor (mediato) ${ }^{107} \mathrm{y}$, por supuesto, en cualquier caso no dejaría de ser insatisfactorio calificar como mero partícipe a quien realiza plenamente el significado específico del hecho, ocupando la posición principal en las conductas de intervención penal ${ }^{108}$.

En cualquier caso, importa subrayar, en particular, que, a partir de las premisas que aquí asumo, no ha lugar a efectuar una caracterización restrictiva de los supuestos de autoría me-

Vid. asimismo CEREZO, P.G., III, pp. 214 s., quien incluye los casos en los que, debido al empleo de coacción, la persona de delante obra al amparo de una causa de inculpabilidad como el estado de necesidad excusante o el miedo insuperable, e incluye también los supuestos de error sobre la prohibición.

107 En cambio, si la conducta de la persona de atrás fuese calificada como de mera participación, no se podría castigar a los sujetos que hubiesen participado en esa conducta, si se acoge la tesis de la opinión doctrinal mayoritaria (que creo correcta) de rechazar el castigo de la participación en una participación (participación en cadena), algo que desde luego, no está previsto (al menos explícitamente) en el CP español. Vid. por todos DÍEZ RIPOLLÉS, P.G., $4^{\text {a }}$ ed., p. 387; MIR, P.G., L.15/28, sobre la base de la razón apuntada más arriba. Además, en el caso concreto de la inducción, el castigo del inductor a dicha conducta se topa con el obstáculo legal adicional de que el art. $28 \mathrm{CP}$ exige para la inducción que el inducido realice un tipo de autoría (el "hecho" al que se refiere el art. 28 tiene que ser un tipo de autoría), y no una conducta de participación; no cabe, pues, una inducción a una conducta de participación. Vid. por todos MIR, P.G., L.15/28 64 .

108 De hecho, conviene recordar que la necesidad de recurrir a la figura de la autoría mediata surgió históricamente vinculada a las lagunas de punibilidad que se derivaban del criterio de la accesoriedad máxima, que exigía una conducta típica, antijurídica y culpable del autor para poder castigar al partícipe. No obstante, aunque posteriormente se impuso el criterio de la accesoriedad limitada (que permitió castigar como participación muchos de los supuestos que resultaban problemáticos con la accesoriedad máxima), no por ello se desconoció que la autoría mediata era una genuina forma de autoría en sentido estricto. Vid. por todos DÍAZ G.-CONLLEDO, 2001, p. 30. 
diata cuando el instrumento se halla en situación de error sobre la prohibición (invencible), como singularmente sucedería si, adoptando como punto de partida la idea del dominio del hecho, se pretendiese restringir la autoría mediata a casos en los que existe una auténtica "manipulación de la lesión"109. Frente a ello, conviene recalcar la idea de que si la persona de atrás provoca el error o mantiene a la persona de delante en la (completa) ignorancia acerca de la dimensión jurídica del hecho, esta se convierte en un genuino instrumento del mismo modo que si la ignorancia versase sobre el significado fáctico ${ }^{110}$; por tanto, la cualidad de instrumento solo se perdería en el caso de que el error fuese vencible ${ }^{111}$.

109 Vid. en este sentido de forma paradigmática BOLEA, 2000, pp. 221 ss., quien, sobre la base de su idea rectora del dominio sobre el riesgo, entiende que (a diferencia de lo que sucede en los casos de error sobre el tipo) "el autor de un hecho antijurídico realizado en error de prohibición puede ser influenciado pero no dominado" y que el dominio de la persona de atrás únicamente podrá afirmarse "cuando la provocación del error de prohibición ponga en marcha un proceso lesivo que suponga un ataque directo para el bien jurídico", lo cual sucederá, en concreto, cuando manipula la situación de tal modo que la persona de delante "tiene razones objetivas para poder confiar en que la información que le están brindando es veraz".

Eso sí, cuestión diferente es que podamos llegar a conclusiones próximas, según indico dos notas más abajo.

110 Esto se admite incluso también desde la perspectiva del dominio del hecho: vid. por todos ROXIN, A.T.,II, § 25, 78; HERNÁNDEZ PLASENCIA, 1996, pp. 192 ss., arguyendo que en tal caso la persona de atrás "está dominando una cualidad, la cualidad 'lesiva' de la acción, proyectada hacia el ordenamiento jurídico, otorgando al sujeto de atrás la dirección de su conducta hacia el resultado y el superior control del acontecimiento fáctico" (p. 193).

111 Y es así como debe salvarse la objeción que formula BOLEA, cuando sostiene que (a diferencia de lo que acontece en los casos de error sobre el tipo) "el informarse sobre la licitud o ilicitud de una conducta es en principio asunto de cada persona individual" (2000, p. 222). En efecto, a mi juicio lo que sucede es, sencillamente, que si el ejecutor inmediato no se ha informado debidamente de dicha ilicitud, pese a que podía hacerlo, el error sobre la prohibición será vencible $\mathrm{y}$, consiguientemente, con arreglo a las premisas que aquí asumo, perderá, ciertamente, su condición de instrumento y pasará a ser un autor inmediato (por más que su responsabilidad pueda verse atenuada), con lo que la persona de atrás será partícipe. 
Asimismo, interesa recordar que, según expuse más arri$\mathrm{ba}^{112}$, en lo que atañe a las situaciones de inexigibilidad, aquí he sostenido la opinión de que la aparición de un instrumento viene dada ya automáticamente por la circunstancia de que el Ordenamiento jurídico exima de responsabilidad penal al ejecutor inmediato (en el CP español, por un estado de necesidad o un miedo insuperable en el instrumento). Si el legislador reconoce la ausencia de libertad en la persona de delante, ello comporta ineluctablemente la aparición de un instrumento, que, a la postre, dará lugar a una autoría mediata si la persona de atrás "se sirve" efectivamente de la persona de delante.

Ello no obstante, hay que reconocer que de esta opinión (que es dominante en la doctrina) se aparta un sector doctrinal, sobre la base de entender que fundamentar la responsabilidad de la persona de atrás a partir de la calificación que el Derecho realiza de la persona de delante supone una quiebra intolerable del "principio de la propia responsabilidad"113.

Sin embargo, esta crítica, que puede ser explicable a partir de una determinada comprensión de la idea rectora del dominio del hecho, no es admisible desde los postulados que aquí acojo, en virtud de los cuales es precisamente (y exclusivamente) el sentido de la actuación de la persona de delante el que permitirá ofrecer el fundamento de la autoría mediata, de tal manera que, si el legislador está reconociendo que la persona de delante obra con falta de libertad, ello nos proporcionará el presupuesto necesario para que dicha persona llegue a convertirse en instrumento al servicio de la persona de atrás; eso sí, obviamente será requisito imprescindible que esta hubiese provocado la situación de inexigibilidad de la persona de delante o, en su caso, que se hubiese aprovechado conscientemente de ella y que obre con la intención de que el hecho delictivo se consume. Por tanto, de acuerdo con esto, no puede decirse que quiebre el prin-

112 Vid. supra III. 3.2.1.

113 Vid. por todos, con indicaciones, HERNÁNDEZ PLASENCIA, 1996, p. 160; BOLEA, 2000, pp. 287 ss. 
cipio de la propia responsabilidad, puesto que el autor mediato debe infringir su norma personal de conducta, realizando efectivamente el hecho a través del instrumento. En otras palabras, es cierto, que, según la posición que aquí mantengo, el reconocimiento de la autoría mediata va a depender de si el ejecutor es o no responsable y que hasta que no se emita el juicio de reprochabilidad sobre el ejecutor no podrá saberse si el instigador es autor o sólo partícipe; pero ello no implica acoger "un método de determinación formal-negativo y accesorio de la autoría mediata" ${ }^{114}$. En efecto, la inculpabilidad de la persona de delante es ciertamente un presupuesto imprescindible para poder hablar de un instrumento, pero no es todavía condición suficiente para determinar la aparición de una autoría mediata de la persona de atrás: la autoría mediata dependerá además de que esta persona realice su propio tipo de acción (que consiste en servirse del instrumento con la intención de que el hecho delictivo se consume) y que lo haga infringiendo su norma personal de conducta (esto es, obrando con dolo o imprudencia con respecto a la utilización del instrumento).

Finalmente, de la segunda tesis (que admite la autoría mediata en casos de culpabilidad disminuida, en la que el instrumento es penalmente responsable) también me ocupé más arriba, al establecer la premisa restrictiva básica en materia de autoría mediata, a saber: que, con carácter general, solo habrá autoría mediata allí donde la actuación que se ejerce sobre otra persona convierte a esta en un auténtico instrumento ciego de la persona de atrás, o sea, allí donde la persona de delante es utilizada materialmente para llevar a cabo una acción de un modo equivalente al empleo de un animal o de una fuerza de la naturaleza, y que, consecuentemente, todos los supuestos en los que la persona de delante es responsable penalmente (por más que su responsabilidad pueda verse atenuada) no dan lugar a la aparición de la figura del genuino instrumento.

114 Como, sin embargo, objeta HERNÁNDEZ PLASENCIA, 1996, pp. 159 ss. 
Y partiendo de esta premisa general ya analicé en concreto el caso en que el instrumento obra en error vencible sobre la prohibición ${ }^{115}$ llegando a la conclusión de que quien obra en esa situación no es un instrumento y, por tanto, la autoría mediata queda excluida.

\subsubsection{Los casos de ausencia de punibilidad}

En fin, si nos atenemos al fundamento del que aquí partimos en materia de autoría mediata, en el que lo único decisivo de cara a su admisión debe ser el dato de que el ejecutor inmediato actúe sin libertad, sin conocimiento de la situación o sin capacidad para comprender el sentido de la acción de la conducta, resulta obvio que la mera presencia de una causa de exclusión de la pena en el ejecutor inmediato no le convierte en un instrumento y, por tanto, no existe autoría mediata en la inducción por parte de la persona de atrás, sino una conducta de participación en el hecho típico, antijurídico y culpable realizado por la persona de delante ${ }^{116}$. Así, sucederá, v. gr., en el caso de que un sujeto induzca a otro a que este lleve a cabo un delito patrimonial incluido en el ámbito del art. 268 CP: la exclusión de la pena del ejecutor inmediato por hurtar un bien del pariente no comportará per se la autoría mediata de la persona de atrás, a no ser que esta hubiese recurrido a alguno de los medios de instrumentalización ya expuestos.

Por lo demás, me interesa recalcar que, a la vista del referido fundamento que aquí acojo para la caracterización del auténtico instrumento ciego, se puede salir al paso de la aguda observación que DÍEZ RIPOLLÉS efectúa a la caracterización

115 Vid. supra III.3.2.1.

116 En sentido similar vid. DÍAZ G.-CONLLEDO, 2001, p. 42, considerando que ello es consecuencia de la adopción de un concepto material de autoría mediata (y de participación mediata), basado en la efectiva instrumentalización de un sujeto por otro, que rompe en buena medida con el principio de responsabilidad en materia de autoría mediata, en lo que ese principio tiene de carga formal. Eso sí, recuérdese que para este penalista dicho concepto material le lleva incluso (a diferencia de lo que aquí sostengo) a admitir supuestos de autor mediato responsable detrás de otro autor inmediato también responsable. 
de DÍAZ G.-CONLLEDO, cuando este admite sin ambages la autoría mediata a través de un instrumento que obra sin culpabilidad e incluso con culpabilidad disminuida. En efecto, DÍEZ arguye que DÍAZ G.-CONLLEDO no da razones convincentes de por qué no extiende la autoría mediata "a otros ámbitos dogmáticos, como por ejemplo la punibilidad, cuál sería el caso si, optando por la otra alternativa mencionada por Díaz GarcíaConlledo para concretar la actuación a través de otro, a saber, la instrumentación de un sujeto por otro, se admitiera la instrumentación por la pretendida persona de atrás de un pariente para que hurte a otro pariente aun cuando el pariente instrumento actúe antijurídica y culpablemente (art. 268)"

A mi juicio, la razón por la cual no cabe aceptar una autoría mediata en este ejemplo estriba en el hecho de que el pariente que es inducido a hurtar no es un verdadero instrumento, en el sentido requerido por el art. 28, en la medida en que se trata de un sujeto que actúa de manera plenamente libre y consciente, con pleno conocimiento del sentido lesivo de su conducta, lo cual es incompatible con la presencia de un genuino instrumento. La exención de pena del art. 268 CP ofrece precisamente el ejemplo más conspicuo de causa personal de exclusión de la pena, basada en razones político-criminales (de política de protección familiar), que se halla situada fuera de la ilicitud y de la culpabilidad, como mero presupuesto de la punibilidad (concebida como cuarta categoría dogmática). Y de ahí que el error sobre esta causa (trátese de un error sobre los presupuestos materiales o fácticos, trátese de un error sobre su existencia jurídica o límites jurídicos) sea, en principio, irrelevante para la opinión dominante, porque el pariente sabe que su conducta es jurídicamente ilícita ${ }^{118}$.

117 DÍEZ RIPOLLÉS, 1998, p. 47, n. 70

118 Vid. MARTÍNEZ-BUJÁN, 2017, pp. 164 s., donde simplemente se admite la posibilidad, apuntada por un sector doctrinal, de que un error sobre la existencia jurídica de dicha causa de exención reciba un tratamiento semejante al del error sobre el carácter penal de la prohibición, no identificable con el error sobre la prohibición. 
En fin, a modo de recapitulación, hay que recordar, una vez más que, el art. $28 \mathrm{CP}$ español nos indica que el autor mediato también realiza (o ejecuta) el hecho, lo que obliga, pues, a mantener el concepto básico de "realización" como característico de toda autoría y, coherentemente, a sustentar un concepto restrictivo de autoría mediata que posea un significado equivalente al de la autoría inmediata o directa: obviamente esa equivalencia significativa no existe cuando el pretendido instrumento es una persona que actúa con total conocimiento de la situación fáctica y con plena consciencia de la ilicitud de su conducta.

\section{Repercusiones sobre supuestos controvertidos}

\subsection{La posibilidad de castigar como partícipe a la persona de atrás}

Vaya por delante una primera (y básica) consideración político-criminal -ya esbozada en páginas anteriores- que se desprende de la caracterización de la autoría de acuerdo con los postulados de la concepción significativa, a saber: la figura de la autoría mediata no resulta tan imprescindible como se revela a partir de otras concepciones sistemáticas (la mayoría), dado que, aunque no existiese dicha figura, la persona de atrás siempre podrá ser castigada como partícipe con tal de que la persona de delante hubiese realizado un tipo de acción. En efecto, recuérdese que, con arreglo al criterio de la accesoriedad mínima objetiva que aquí se propugna, la persona de atrás podrá ser castigada ya desde el momento en que la persona de delante realice un tipo de acción objetivamente relevante y ofensivo para un bien jurídico penal, aunque esta hubiese obrado sin dolo o imprudencia o hubiese obrado al amparo de una causa de justificación. En cambio, si se acoge el dominante criterio de la accesoriedad limitada, la autoría mediata se revela como una institución imprescindible para castigar a la persona de atrás en los casos en los que el instrumento, si bien realiza el tipo de acción (en la terminología de la opinión dominante, la parte objetiva del tipo), actúa sin dolo o 
imprudencia o cubierto por una causa de justificación ${ }^{119}$; incluso si se adopta el criterio de la accesoriedad mínima subjetiva (que requiere en la conducta del autor no solo la realización del tipo de acción, sino además la infracción de la norma personal de conducta) la autoría mediata será imprescindible para castigar a la persona de atrás cuando la persona de delante actúa sin dolo o imprudencia.

Con todo, y sin perjuicio de lo que antecede, hay todavía un supuesto en el que (aun partiendo de la accesoriedad mínima objetiva) la autoría mediata resulta necesaria, esto es, cuando la persona de delante no realiza una conducta típica, incluyendo aquí el caso de que falte en el pretendido instrumento el especial elemento subjetivo requerido por el tipo (v. gr., el ánimo de lucro en el delito de hurto). En este supuesto no será posible castigar al sujeto de atrás como inductor o cooperador necesario ${ }^{120}$.

Ahora bien, a mayores, no puede dejar de insistirse en algo que ya se apuntó más arriba, a saber: que, evidentemente, no es lo mismo que la persona de atrás sea calificada como partícipe que lo sea como auténtico autor mediato, habida cuenta de que en esta segunda hipótesis se abre la posibilidad de admitir la participación (señaladamente la inducción) de terceras personas en la propia conducta de la persona de atrás que actúa como

119 Vid. por todos MIR, P.G., L.14/62 ss.

120 En sentido coincidente vid. ya RODRÍGUEZ MOURULLO, 1969, pp. 277 ss., y 1972, pp. 806 s., con referencia a una accesoriedad mínima que, además, vendría a coincidir con la que aquí sustento, dado que este penalista acogía el tradicional sistema neoclásico en el que dolo e imprudencia no se incluían en el tipo, sino que eran formas de culpabilidad y, por tanto, en la tipicidad solo se incluían los elementos objetivos y, en su caso, el especial elemento subjetivo (como, v. gr., el ánimo de lucro). Haciéndose eco de ello vid. asimismo CEREZO (P.G., III, p. 214), afirmando coherentemente que no siempre será posible castigar al sujeto de atrás "como inductor o cooperador necesario, aunque se parta del criterio de la accesoriedad mínima": ciertamente para este penalista dicha accesoriedad mínima es subjetiva (en el sentido de que incluye dolo e imprudencia en el tipo) pero la afirmación es coherente porque lo relevante es que incluye también los especiales elementos subjetivos del injusto en la tipicidad. 
verdadero autor (mediato) ${ }^{121}$; y que, por supuesto, en cualquier caso no dejaría de ser insatisfactorio calificar como mero partícipe a quien realiza/ejecuta plenamente el significado específico del hecho, ocupando la posición principal en las conductas de intervención penal.

\subsection{El caso del sedicente "instrumento doloso sin in- tención"}

Ello no obstante, en segundo lugar, cabe decir que, curiosamente, desde la perspectiva opuesta, la concepción significativa va a permitir calificar, sin duda, como autor mediato al sujeto que se vale del denominado "instrumento doloso sin intención" (o "sin el elemento subjetivo egoístamente delimitado") $)^{122}$.

Como ya anticipé más arriba, desde la perspectiva de la concepción significativa es ya conceptualmente incorrecto hablar de un "instrumento doloso sin intención", figura reconocida, empero, por la opinión dominante: y es que, en efecto, si el agente obra sin el específico elemento subjetivo del tipo de acción, no hay tipo, y, por tanto, carece de todo sentido afirmar que obra con dolo, por mucho que conozca y quiera realizar los elementos objetivos del tipo: así, si, v. gr., en el conocido ejemplo de los gansos el criado obra sin ánimo de lucro (o ánimo de apropiación definitiva de la cosa), no realiza ya el tipo de acción del hurto, por más que sepa que los gansos de los que se apodera son de propiedad ajena. De ahí se infiere que no exista proble-

121 Vid. lo expuesto supra en el epígrafe 3.2.4., al examinar los casos de ausencia de culpabilidad.

122 Como es sabido, esta figura ha venido despertando una especial atención en la doctrina y jurisprudencia alemanas al hilo de los delitos de hurto y apropiación indebida (vid. por todos indicaciones en BOLEA, 2000, pp. 446 ss.), a diferencia de lo que ha venido sucediendo en España (ibid., pp. 458 ss.). Con todo, creo que el menor interés de la doctrina española reside en un equívoco punto de partida, acogido ya por GIMBERNAT (1966, p. 227), en virtud del cual no se analiza el genuino caso del instrumento doloso sin intención, sino una variante en la cual el mediador sí realiza el tipo, como explico más abajo. 
ma alguno para calificar como autor mediato al señor (sujeto de atrás) que actúe movido por tal ánimo específico ${ }^{123}$.

Y repárese en que, desde las bases de la concepción significativa, tal conclusión se asienta en un fundamento convincente $^{124}$. Ciertamente, dado que aquí el mediador (la persona de delante) actúa sin el elemento subjetivo específico, no existe ya un tipo de acción relevante y ofensivo, con lo que, incluso partiendo del criterio de la accesoriedad mínima objetiva que aquí se acoge, en dicha conducta no cabe admitir una participación punible porque la persona de delante no es ya un autor en el básico sentido lógico-gramatical. Ahora bien, precisamente por esa misma razón, no hay inconveniente alguno en entender que ese mediador (que, insisto, no está realizando ya un tipo penal, sino el sustrato material del tipo) es un genuino instrumento en manos del hombre de atrás, que será un verdadero autor mediato.

La opinión dominante, que, como es sabido, rechaza en estos casos la autoría mediata, alega que el mediador actúa li-

123 A esta conclusión llega también un sector minoritario, a partir de otras concepciones sistemáticas. En la doctrina española vid. MIR (P.G., L.14/6466), a pesar de mantener la caracterización tradicional sobre los "elementos subjetivos del injusto". Él lo basa en su concepción de la autoría como relación de pertenencia del delito, argumento que le sirve también para admitir la autoría mediata en el caso del instrumento doloso no cualificado, como explicaré más abajo.

A conclusión análoga llega también, según indiqué más arriba, CEREZO (P.G., III, p. 214), sobre la base de entender que no siempre será posible castigar al sujeto de atrás "como inductor o cooperador necesario, aunque se parta del criterio de la accesoriedad mínima", en la medida en que, a su juicio, el elemento subjetivo del injusto se incluye en el tipo. Por ello, resalta entonces la necesidad de prever expresamente la figura de la autoría mediata. Con todo, vid. las ulteriores reflexiones de este penalista que recojo más abajo.

124 Con ello pretendo salir al paso de objeciones como la esgrimida por DÍAZ G.-CONLLEDO (2001, p. 5), frente a la tesis de la autoría mediata sustentada por MIR, a saber, que la calificación de autor mediato para la persona de atrás en tal caso resulta muy discutible, desde el momento en que no parece que exista un fundamento material (más allá de la aparición de una laguna de punibilidad, algo no suficiente) que justifique la autoría mediata del intraneus. 
bremente y con conocimiento de la situación ${ }^{125}$. Sin embargo, cuando alega esto, dicha opinión dominante no está ya en rigor refiriéndose al genuino caso del instrumento doloso sin intención, sino a una variante en la cual el mediador sí realiza el tipo, porque actúa movido por el ánimo específico requerido por el tipo $^{126}$. Es obvio, entonces, que situados en esta hipótesis, no

125 Vid. por todos GIMBERNAT, 1966, p. 227; RODRÍGUEZ MOURULLO, 1972, pp. 809 s.; QUINTERO, 1974, p. 99; BOLEA, 2000, p. 459.

Vid. además DÍEZ RIPOLLÉS, P.G., $4^{\mathrm{a}}$ ed., p. 371, quien descarta asimismo la autoría mediata en estos casos de delitos con elementos de acceso restringido, si bien sigue manteniendo aquí la existencia de una laguna de punibilidad: a tal efecto, plantea este penalista el ejemplo del dueño de la tienda que da instrucciones a su dependiente "para que adquiera a muy bajo precio una moto hurtada, con el fin de que el dueño trafique con ella más tarde y obtenga un beneficio alto al venderla a precio casi normal (art. 298.1 y 2)", caso que él considera atípico porque "el instrumento no realiza la conducta típica, al faltarle el elemento subjetivo de lo injusto de la finalidad de traficar" y porque "la persona de atrás no puede ser autora mediata pues (scil., pese a) su existente propósito de traficar debe acceder de forma inmediata al tipo, y no a través del instrumento".

Vid., asimismo, DÍAZ G.-CONLLEDO, 2001, p. 50, con indicaciones, añadiendo que la calificación de autor mediato para la persona de atrás en tal caso resulta también "muy discutible"

126 Esta aguda observación la tomo de MIR (P.G., L.14/65), quien, con toda razón, responde que el argumento de la opinión dominante solo sería decisivo en el caso de que el mediador hubiese realizado el tipo, como sucede en el clásico ejemplo de los gansos en el que la doctrina española viene asumiendo el razonamiento de GIMBERNAT (1966, p. 227), siguiendo a MAURACH y a ROXIN, consistente en entender que el hurto no requiere el ánimo de quedarse con la cosa para sí, sino que basta tomarla con la intención de disponer de ella (p. ej., para regalarla), que es lo que en el ejemplo considerado haría el criado al entregar los gansos a su principal. Asimismo, se hacen eco de la observación de MIR otros penalistas como HERNÁNDEZ PLASENCIA, 1996, pp. 281; CEREZO, P.G., III, p. 215.

Ello se ve claramente también en la opinión de DÍAZ G.-CONLLEDO (2001, p. 50), cuando se refiere a este ejemplo en los siguientes términos: "el ejemplo clásico es el del sujeto que, queriéndose apropiar del algún objeto de valor del vecino, le pide a su criado (sin coacción, ni orden vinculante, etc.) que lo coja y se lo dé, lo que éste hace con plena consciencia de la ajenidad de la cosa". Pues bien, tras exponer la tesis de la autoría mediata y criticarla, DÍAZ añade que "sin embargo, en estos supuestos a menudo solo 
habría conveniente en entender, con la opinión dominante, que el mediador realiza el tipo penal y que, si concurren los restantes requisitos, podrá llegar a ser un genuino autor inmediato del delito de que se trate, plenamente responsable, y en esa conducta la persona de atrás podrá ser castigada a título de inducción. Es más, con arreglo a la concepción significativa, el mediador ya realizaría siempre un tipo de acción relevante y ofensivo, y sería, por tanto, un autor en sentido lógico-gramatical, en el que cabría ya una participación punible, aun cuando, a la postre, el mediador no fuese responsable penalmente por concurrir en él una causa de exclusión de la ilicitud o una causa de exclusión de la reprochabilidad.

Pero insisto en que el argumento de la opinión dominante (y el tratamiento penal que ella propone) no sirve cuando el mediador actúa sin el específico elemento subjetivo. Como acertadamente aduce MIR, en referencia a la tesis de la opinión dominante, "no siempre será posible esta solución. Supongamos que el criado no sabe que el señor pretende quedarse con los gansos. Pese a ello seguirá tomando los gansos ajenos dolosamente, pero sin ánimo de apropiación. Aquí será innegable la autoría mediata" 127 .

aparentemente se produce la impunidad, pues lo que ocurre es que están mal planteados. Como señalan ROXIN o GIMBERNAT, entre otros, el ánimo de lucro en el hurto puede entenderse como ánimo de apropiación (lo que me parece correcto) y, por tanto, el criado actúa con ese ánimo, pues dispone de la cosa mueble ajena que ha tomado como propia al dársela al señor, quien, a su vez, podría ya ser calificado de inductor del hurto (...)".

Por mi parte, simplemente aclaro que si nos situamos en esta hipótesis, no puedo menos que compartir la opinión expuesta, porque participo de la idea de que el ánimo de lucro en el hurto debe ser entendido como un ánimo de apropiación (sobre ello vid. ampliamente MARTÍNEZ-BUJÁN, 2013-a, pp. 236 s., calificando, por tanto, el delito de hurto como delito de intención y no de tendencia intensificada), y, consecuentemente, el criado actúa ya con ese ánimo.

127 MIR, P.G., L.14/66. A esta hipótesis se refiere también BOLEA (2000, p. 459), al diferenciar del referido caso propuesto por la opinión dominante el supuesto en el que "la falta del elemento subjetivo tiene su origen en un error sobre la propia intención del hombre de atrás o sobre la ajenidad de 
A esta observación de MIR simplemente añado, como ulterior matización desde la óptica de la concepción significativa, que, en rigor, no cabe hablar de dolo en la conducta del criado, porque, si bien sabe que está tomando una cosa mueble ajena, no lo hace con ánimo de lucro (o de apropiación), y entonces no realiza ya el tipo del hurto, con lo cual carece de todo sentido de hablar de dolo (o de "actuación libre o con conocimiento de la situación") con relación a una conducta que no es ya penalmente típica $^{128}$.

la cosas" (o sea, "cuando el criado no sabe que el amo pretende quedarse con las gallinas o cree que el amo es el dueño de las mismas"); ante tal supuesto, esta penalista se limita a afirmar que "habrá que acudir a las reglas desarrolladas para los demás supuestos de error de tipo", con lo cual está admitiendo implícitamente la autoría mediata.

Por lo demás, debe compartirse también con MIR la ulterior observación de que en el caso planteado el criado no posee la tenencia de la cosa ni es un servidor de la tenencia ajena: "si sucediera una de estas dos otras cosas podría calificarse el hecho como delito de estafa en autoría directa del que engaña al tercero, pues en este delito el engañado puede ser distinto del sujeto pasivo" (cfr. MIR, P.G., L.14/66, n. 51, citando la previa opinión de WELZEL). En efecto, esta calificación sería la correcta, a la luz de la regulación del delito de estafa en el art. 248 (el acto de disposición que lleva a cabo el engañado, puede ser en perjuicio "propio o ajeno") y es la que venía ya sosteniéndose desde la caracterización de ANTÓN ONECA (1957, pp. 5 ss.) sobre la estafa con anterioridad al CP de 1995. Vid. además, en este sentido, HERNÁNDEZ PLASENCIA, 1996, pp. 282, con ulteriores matices.

128 Con esta matización pretendo salir al paso de una objeción, dirigida a la referida observación de MIR, que efectúa CEREZO (P.G., III, p. 215, n. 43), quien escribe que "en contra del parecer de Mir Puig y de Hernández Plasencia creo, además, que la ausencia de un elemento subjetivo del injusto en el hombre de delante, que actúe libremente y con conocimiento de la situación, no sería suficiente para fundamentar la autoría mediata o el dominio del hecho del hombre de atrás".

Me interesa insistir en que esta objeción de CEREZO pudiera cobrar sentido si parte de la premisa (que aquí se rechaza) de que el dolo forma parte de la tipicidad, como este penalista, coherentemente asume. Pero no posee sentido si el dolo se extrae del tipo: de ahí que dicha objeción no pueda ser esgrimida frente a una concepción que excluya el dolo del tipo, como, v. gr., la que, adoptando el enfoque neoclásico, mantenía RODRÍGUEZ MOURULLO, 1969, pp. 469 ss.

Con todo, al margen de lo anterior, también cabe poner en tela de juicio la afirmación de CEREZO, referida a la persona de delante, cuando predica de 
Por lo demás, desde el punto de vista de la opinión dominante se ha propuesto otra solución, al margen de la autoría mediata, para evitar la impunidad en este caso, aun partiendo de la base de que el sujeto delante obre sin el elemento subjetivo específico requerido por el tipo, a saber: la solución de considerar que la persona de atrás realiza inmediatamente el tipo. Así, operando de nuevo con el citado ejemplo de los gansos, razona DÍAZ G.-CONLLEDO que "no me parece descabellado decir que el señor toma cosa mueble ajena contra la voluntad de su dueño, aunque no lo haga directamente de su propietario, de manera que, como él sin duda actúa con ánimo de lucro, sería autor del hurto y el criado, si se cree que no actuó con ánimo de lucro (por partirse de otra concepción respecto de este elemento subjetivo del hurto) cooperador necesario ... del señor" ${ }^{129}$.

Sin embargo, ante esta solución cabe objetar que resulta discutible interpretar que el señor está realizando/ejecutando el hecho típico del hurto ${ }^{130}$, al menos desde la perspectiva formal que aquí adopto con base en la concepción significativa, lo cual

ella el obrar sin el elemento subjetivo del tipo y, a la vez, "con conocimiento de la situación": frente a ello, cabe oponer que si la persona de delante obra sin dicho elemento subjetivo (v. gr., sin ánimo de lucro, propio o ajeno) no puede obrar con conocimiento de la situación, porque obra en situación de error. Es más, el propio CEREZO lo viene a admitir implícitamente cuando, aparte de su genérica afirmación que recogí más arriba, sobre la necesidad de reconocer la autoría mediata en tal supuesto (p. 214), previamente había afirmado que "como consecuencia de un error sobre un elemento del tipo puede faltar en el instrumento no sólo el dolo, sino también un elemento subjetivo de lo injusto, por ejemplo el ánimo de lucro, en el hurto" (p. 215). Por lo demás, a esta hipótesis se refiere también ROXIN (A.T., II, § 25/157) cuando plantea el caso de que la persona de atrás mienta a la de delante, diciéndole querer tener la cosa solo para un uso temporal: aquí falta no solo el elemento subjetivo del injusto, sino también el dolo (el mediador no quiere cometer un hurto sino un furtum usus), por lo que se trata de un instrumento que obra en error de tipo y, por ende, es patente la autoría mediata de la persona de atrás.

129 DÍAZ G.-CONLLEDO, 2001, p. 50.

130 Como acabo de indicar DÍEZ RIPOLLÉS (P.G., p. 371) entiende que en estos casos la persona de atrás no puede ser autor porque no accede de forma inmediata al tipo, sino solo a través del instrumento. 
se evidencia con claridad, además, en la hipótesis de que el criado, pese a haberlo intentado, no hubiese conseguido consumar el delito de hurto. Parece obvio que en esta hipótesis el señor no habría comenzado la ejecución del delito a título de autor inmediato, pese a que el criado sí habría realizado la vertiente objetiva del tipo penal (no, en cambio, la subjetiva, al no obrar con el especial elemento subjetivo requerido por el tipo). De ahí que esta solución resulte, a mayores, político-criminalmente insatisfactoria, dado que en la hipótesis de la tentativa el hecho tendría que quedar sin castigo: de un lado, el criado no puede realizar una tentativa del tipo de acción del hurto (en la tesitura de la opinión dominante, no puede realizar el tipo de injusto o el tipo antijurídico) por ausencia del ánimo de apropiación, por lo que en esa conducta no cabe castigar como partícipe al señor; de otro lado, el señor tampoco puede ser castigado como autor inmediato de una tentativa de hurto. En cambio, si, como aquí se propone, consideramos que el criado es un verdadero instrumento del que se sirve el señor, este podrá ser castigado como autor mediato de una tentativa desde el momento en que el criado comienza la ejecución (objetiva) del hurto (o, incluso, desde que ordena a su criado que se apodere de los gansos, si, como creo correcto, se admite que la tentativa comienza ya en ese momento para el autor mediato).

Pero dejando al margen la hipótesis de la tentativa y regresando a la de la consumación, no puede desconocerse que (más allá del ejemplo del hurto con el que opera DÍAZ G.CONLLEDO), son imaginables otros ejemplos en los que parece mucho más difícil todavía admitir que la persona de atrás pueda ser calificada como autor inmediato del delito ${ }^{131}$, sin per-

131 De ello es consciente el propio DÍAZ G.-CONLLEDO (2001, p. 50), cuando a lo que anteriormente expone añade que "si no se admitiera alguna de las soluciones señaladas" cabría acudir a la receptación (por más que no crea que "la calificación de la conducta del señor que mejor cuadre sea la de receptación”), y “en otros supuestos diferentes -fundamentalmente en cuanto al conocimiento por parte de del que actúa de manera inmediata- cabe castigar, si no puede fundamentarse la autoría mediata de hurto, al sujeto de atrás 
juicio de que en algún otro caso tal solución sea, en cambio, más sencilla $^{132}$.

Finalmente, en estos supuestos del denominado instrumento doloso sin intención pudiera pensarse también en la posibilidad de recurrir a la regla de actuaciones en nombre de otro, con objeto de hacer responder al mediador. Sin embargo, tal solución no resulta factible a la vista de la regulación del art. 31 del CP español.

Por una parte, a la aplicación del art. 31 cabría oponer que en este precepto no tiene cabida el supuesto del elemento subjetivo egoístamente delimitado, en la medida en que se interprete que este elemento no es una "relación", una "cualidad" o una "condición" personal. No obstante, entiendo con la opinión mayoritaria ${ }^{133}$ que no hay obstáculo para admitir que dicho ele-

como autor de una estafa, y tal vez en algún caso pudiera ser de aplicación el delito de apropiación indebida. De todas maneras, la solución a estos supuestos (que no necesariamente han de ser el del hurto del ejemplo), que no será la de construir una autoría mediata, depende del delito en cuestión y de la concreta configuración del caso".

Por lo demás, obviamente, hay que coincidir con DÍAZ en este último aspecto, puesto que, efectivamente, son imaginables casos de instrumento doloso sin intención en los que cabría calificar al sujeto de atrás como verdadero autor inmediato, como indico en la nota siguiente.

132 Así, creo que sucede en el aludido ejemplo (propuesto por DÍEZ RIPOLLÉS, P.G., p. 371) del dueño de la tienda que da instrucciones a su dependiente "para que adquiera a muy bajo precio una moto hurtada, con el fin de que el dueño trafique con ella más tarde y obtenga un beneficio alto al venderla a precio casi normal (art. 298.1 y 2)", caso que él considera, por cierto, atípico porque "la persona de atrás no puede ser autora mediata pues (scil., pese a) su existente propósito de traficar debe acceder de forma inmediata al tipo, y no a través del instrumento". Entiendo que en este caso, si bien habría efectivamente problemas para interpretar que el sujeto de atrás "adquiere" la moto hurtada, no habría inconveniente en interpretar, empero, que sí la "recibe" o la "oculta", verbos que también son típicos en el art. 298-2 CP, por lo que el dueño de la tienda sería un autor inmediato del delito, y el sujeto de delante podría ser cooperador necesario si conoce todos los elementos del tipo de acción realizado por el dueño, incluido el elemento subjetivo específico del ánimo de traficar

133 Vid. por todos DÍEZ RIPOLLÉS, P.G., p. 374. 
mento subjetivo es, al menos, una "condición" requerida por la correspondiente figura de delito para que una persona pueda ser sujeto activo de ella.

Ahora bien, por otra parte, lo que sí me parece un obstáculo insalvable en la genuina hipótesis de instrumento doloso sin intención (o sea, aquella en la que la persona de delante obra sin el específico elemento subjetivo del tipo) es el cumplimiento del requisito de obrar "en nombre o en representación" de la persona de atrás, puesto que en rigor la persona de delante nunca puede obrar así, desde el momento en que desconoce que tal elemento subjetivo concurra en la persona de atrás, $\mathrm{y}$, por tanto, no cabe afirmar que pasa a ocupar la posición de esta persona.

Obviamente la cuestión se plantea en términos diferentes en la hipótesis en la que la persona de delante conoce la existencia del elemento subjetivo específico en la persona de atrás (el criado sabe que el señor obra movido por el ánimo de apropiación), dado que aquí sí cabría entender que el mediador obra también con el especial elemento subjetivo (en el sentido que apuntaba un sector doctrinal); pero en esta hipótesis la persona de delante (el criado) ya está realizando inmediatamente el tipo, y no hay necesidad de acudir al art. 31, puesto que será autor (inmediato), a tenor del art. 28 , y el sujeto de atrás, inductor.

\subsection{Límites. Casos en los que no es posible admitir la autoría mediata: delitos especiales, delitos de propia mano, delitos con modalidades limitadas de acción y delitos impru- dentes realizados por la persona de delante}

En tercer lugar, la utilidad político-criminal específica que se deriva de la caracterización de la autoría de acuerdo con los postulados de la concepción significativa se comprueba en aquellos supuestos en los que no es posible admitir la autoría mediata, a la vista de la peculiar estructura típica del delito de que se trate. Y es que, en efecto, por más que ahora con el CP de 1995 contemos con un precepto en la Parte general que admita 
y defina la autoría mediata ${ }^{134}$, siguen existiendo numerosos tipos de la Parte especial en los que, según la opinión dominante, la autoría mediata no es factible porque lo impide ya el tenor literal del tipo, que formalmente restringe su realización a determinados sujetos o a determinadas acciones corporales ${ }^{135}$ : así sucede, desde luego, en los delitos especiales, pero también (según la opinión mayoritaria) en los delitos de propia mano y (según un sector) en los delitos con modalidades limitadas o tasadas de acción ${ }^{136}$. Comoquiera que en tales casos solo será posible castigar a la persona de atrás como partícipe, el sistema de la concepción significativa permitirá eludir las posibles lagunas de punición,

134 Antes de la regulación expresa de la autoría mediata en el vigente CP la opinión dominante ya venía reconociendo que la imposibilidad de admitir la autoría mediata en los supuestos que enumero a continuación en el texto no se derivaba de la ausencia de previsión legal de esta clase de autoría, sino de la vigencia del principio de legalidad, desde el momento en que el autor mediato no podía realizar ya el tenor literal de determinados tipos. Vid. por todos DÍAZ G.-CONLLEDO, 1991, p. 470, n. 193.

Por tanto, aunque tras la publicación del nuevo CP de 1995 se le otorgue carta de naturaleza en la Parte general, la autoría mediata es, con arreglo al concepto integrado y restrictivo de autor que expuse más arriba, una genuina clase de autoría y no una cláusula de extensión de la autoría en sentido estricto.

135 Y si lo que se expone en el texto se sostiene por parte de la opinión dominante, con base en diferentes concepciones sistemáticas, con mayor poder de convicción habrá de mantenerse con arreglo a la concepción significativa de la acción, en el seno de la cual adquiere un protagonismo absoluto la función negativa que posee el tenor literal de los términos típicos a la hora de excluir una realización típica que no se ajuste completamente al significado común de la palabras incluidas en la figura legal. Vid. sobre ello ya VIVES, 1977, p. 173.

Por lo demás, conviene reiterar que, si dejamos al margen estos tipos que restringen expresamente su realización a determinados sujetos o a determinadas acciones corporales, ningún inconveniente existirá para admitir, con carácter general, la autoría mediata aunque no haya una "ejecución física (directo-corporal)" del tipo. Cfr. ya RODRÍGUEZ MOURULLO, 1969, p. 476 (posteriormente, 1972, p. 811), subrayando que la base del concepto restrictivo de autor viene dado por la idea de realización y no por la de ejecución física. Vid. además, entre otros, VIVES, 1977, pp. 181 ss.; DÍAZ G.-CONLLEDO, 1991, pp. 475 ss.

136 Vid. por todos ya GIMBERNAT, 1966, pp. 225 ss. 
al contentarse (para poder castigar a la persona de atrás como partícipe) con la mera realización de un tipo de acción por parte del autor inmediato que actúa como instrumento.

En el caso de los delitos especiales propios la cuestión se plantea en términos claros y unívocos para la totalidad de la doctrina $^{137}$, en lo que se refiere al supuesto en que un extraneus instrumentalice a un intraneus, dado que en estos delitos el extraneus nunca podrá ser autor mediato del delito especial ${ }^{138}$, en la medida en que no reúne la cualificación necesaria para ser autor y, por tanto, no puede "realizar el hecho" en el sentido del art. $28 \mathrm{CP}^{139}$. Pero, a su vez, si se acoge el dominante criterio de la accesoriedad limitada el extraneus tampoco podrá ser castigado como partícipe en el delito especial propio, en tanto en cuanto el intraneus no realice una conducta típica y antijurídica ${ }^{140}$. Así, ciertamente nunca podrá existir autoría mediata en, v. gr., un de-

137 Eso sí cuestión diferente es dilucidar cuándo nos encontramos ante un genuino delito especial propio (o delito especial en sentido estricto), porque un amplio sector doctrinal entiende que realmente no lo son los llamados delitos especiales de dominio (o, denominados también, delitos de posición), que no incluyen ningún elemento de infracción de deber (como, v. gr., el art. $257 \mathrm{CP}$ ), categoría que además -en opinión de algunos penalistas- poseería un ámbito mayor, al incluir en ella delitos que, para la opinión mayoritaria, poseerían un componente de infracción de deber (como, v. gr., el delito del art. 305), con la consecuencia de que en estos cabría la autoría mediata del extraneus. Vid. por todos indicaciones en MARTÍNEZ-BUJÁN, P.E., pp. 316 s., 321 y 567, en referencia singularmente a la tesis de ROBLES, 2003, pp. 240 ss. y 2007 , pp. 129 ss.

138 Evidentemente, recuérdese que ningún problema habrá para admitir la autoría mediata en la hipótesis inversa: un intraneus utiliza a un extraneus como un verdadero instrumento. Vid. por todos, con indicaciones, HERNÁNDEZ PLASENCIA, 1996, p. 306; DÍEZ RIPOLLÉS, 1998, p. 52.

139 Este supuesto, conocido también como el caso del testaferro, se diferencia del previsto en el art. $31 \mathrm{CP}$, dado que en este precepto el extraneus accede ya inmediatamente a los elementos del tipo que son de acceso no restringido, y es entonces cuando el art. 31 le permite acceder al elemento típico restringido, consistente en la especial cualidad personal. Vid. por todos DÍEZ RIPOLLÉS, 1998, p. 52 y n. 86. Vid. además MARTÍNEZ BUJÁN, P.E., pp. $566 \mathrm{~s}$.

140 Vid., entre otros, GIMBERNAT, 1966, pp. 229 ss.; QUINTERO, 1974, pp. 105 s.; MIR, P.G., L. 14/78; COBO/VIVES, P.G., $5^{\mathrm{a}}$ ed., p. 751; DÍAZ G.- 
lito de prevaricación, si el particular engaña al juez para que este dicte una sentencia injusta; pero, desde la perspectiva de la concepción aquí mantenida y a diferencia de la posición mayoritaria que asume el criterio de la accesoriedad limitada ${ }^{141}$, el juez realiza el tipo de acción (relevante y ofensivo) de la prevaricación judicial, $y$, aunque él no sea penalmente responsable por incurrir en un error personalmente invencible sobre dicho tipo, el extraneus podrá ser castigado como partícipe en el tipo de acción realizado por el juez, que es la calificación jurídica materialmente más satisfactoria ${ }^{142}$, sin perjuicio de aplicar la (potestativa) regla contenida en el vigente art. 65-3 CP, que sin duda es de aplicación en el caso de los delitos especiales propios. Y algo similar sucederá en los casos en que el intraneus instrumento actúe de forma justificada, casos en los que la concepción significativa permitirá sancionar a la persona de atrás, extraneus, como partícipe en el tipo de acción realizado por el intraneus, por más que éste quede (personalmente) exento de responsabilidad penal.

CONLLEDO, 1996-2, p. 1285, 2001, p. 48, EPB, 2002, p. 148, 2004, p. 53. Incluso si se acoge el criterio de la accesoriedad mínima subjetiva, el hecho también debe quedar impune, porque el intraneus no habría realizado una conducta típica (con dolo o imprudencia) y, por tanto, en esa conducta no se podría participar: así vid., coherentemente, con su premisa HERNÁNDEZ PLASENCIA 1996, p. 307.

141 Precisamente, para evitar la impunidad en estos casos, partiendo del criterio de la accesoriedad limitada, y poder castigar al partícipe cuando el autor obró realmente sin el dolo típico, el TS ha recurrido en algunas ocasiones (que a todas luces consideraba, con razón, materialmente merecedoras de castigo) a razones extravagantes y erróneas. Vid. MARTÍNEZ-BUJÁN,

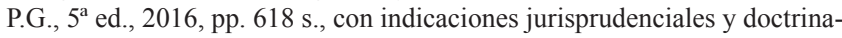
les; vid. además MOLINA, 2017, p. 750, quien añade la más reciente STS $26 / 3 / 2013$, en la que un clarísimo supuesto de error sobre el tipo se transmuta, por arte de magia, en un error sobre la prohibición.

142 Así lo reconoce, p. ej., DÍAZ G.-CONLLEDO, 2001, p. 48, aduciendo que de lege ferenda "parece preferible que se le pudiera castigar, aunque tal vez habría que tener en cuenta su mayor lejanía, como extraneus al injusto específico del delito especial, a la hora de determinar su responsabilidad". Por mi parte, simplemente aclaro que en el CP vigente esa "mayor lejanía" puede tenerse en cuenta a través de la regla del art. 65-3, según indico a continuación en el texto. 
Y repárese en que para la doctrina dominante no hay forma de castigar la conducta del extraneus.

Ilustrativa al respecto es la opinión de TIEDEMANN, al comentar el art. 13-3 de la Propuesta de Eurodelitos ${ }^{143}$, cuando reconoce que, dado que los extranei solo pueden ser partícipes $^{144}$, como sucede en la mayoría de los Ordenamientos jurídicos europeos, pueden surgir lagunas de punibilidad cuando el hecho principal del intraneus no cumple los presupuestos de la accesoriedad (que -recuérdese- la Propuesta de Eurodelitos concibe como accesoriedad limitada), por ejemplo, porque actúa de manera no dolosa ${ }^{145}$.

Y es que, efectivamente, por un lado, según señalé más arriba, la regla del actuar por otro no sirve para solventar estos casos, puesto que, según el art. $31 \mathrm{CP}$, el extraneus debe actuar "en nombre o en representación de otro", algo que no sucede en el caso del testaferro. Por otro lado, tampoco la vía de la comisión por omisión, ni la vía de la construcción de los delitos de infracción de un deber aportan aquí solución alguna ${ }^{146}$.

143 Este precepto, conforme a la redacción pergeñada por el propio TIEDEMANN en colaboración con SCHÜNEMANN, establece que "en aquellos casos en los que la punibilidad se fundamenta en especiales circunstancias o cualidades personales sólo puede ser autor la persona en quien concurran, o asuma, las funciones descritas en estos elementos".

144 En el art. 16-3 de la Propuesta de Eurodelitos se admite el castigo del partícipe extraneus en el delito especial realizado por el intraneus: "los elementos personales que pertenezcan al injusto del hecho se imputarán a inductores y cómplices cuando concurran en el autor y tengan conocimiento de ello".

145 Vid. TIEDEMANN, 2000, p. 94, quien extiende la observación a los delitos de propia mano. Ello no obstante, este penalista entiende que estas lagunas de punibilidad han de "asumirse, puesto que el extraneus no se ve afectado por un deber especial y solo puede realizar un injusto derivado". Por ello, prosigue TIEDEMANN, podrá proponerse como modelo de una regulación semejante a la de los arts. 14 y 28 del StGB alemán.

En concreto, para el castigo de la inducción y de la complicidad, el art. 16 (apartados 1 y 2) de la Propuesta de Eurodelitos exige la realización de una conducta dolosa y antijurídica del autor.

146 Cfr. DÍAZ G.-CONLLEDO, 2001, p. 48. 
En fin, ni siquiera podría mantenerse en la actualidad la tesis que sostuvieron LUZÓN y DÍAZ G.-CONLLEDO, interpretando que algunos de estos supuestos podrían ser reconducidos al primer inciso del antiguo art. $14,2^{\circ}$ CP 1944/1973, referido a los que fuerzan a otro a ejecutar el hecho, lo cual permitía solucionar los casos en los que el extraneus hubiese empleado fuerza (entendida en sentido amplio, como comprensiva de la intimidación) sobre el intraneus instrumento ${ }^{147}$. Por tanto, y con independencia de que esta tesis solo permitía resolver determinados supuestos, lo cierto es que el vigente CP de 1995 ha suprimido la referencia a los supuestos de forzar. De ahí que DÍAZ G.-CONLLEDO, tras tener que reconocer que, desde su perspectiva de la accesoriedad limitada, "seguirán produciéndose lagunas de punición indeseables", se vea obligado a reclamar aquí una solución de lege ferenda, que podría consistir en una cláusula general ad hoc (aunque seguramente limitada a ciertos grupos de delitos), del mismo modo que, para solucionar el problema de la actuación por otro, se ha establecido la cláusula del art. $31 \mathrm{CP}$ de $1995^{148}$.

Asimismo, aunque el tema haya sido discutido, algo similar a lo que se acaba de exponer con relación a los delitos especiales propios cabe predicar, a mi juicio, de la práctica totalidad de los delitos especiales impropios (esto es, de aquellos que poseen un carácter "limitadamente personal"), si se entiende -como creo correcto- que en ellos la responsabilidad del extraneus debe ser siempre exigida a partir del delito especial y no del delito común correspondiente ${ }^{149}$. Ciertamente, en tal caso un

147 Vid. entre otros trabajos DÍAZ G.-CONLLEDO, 2001, pp. $48 \mathrm{~s}$.

148 2001, p. 49

149 Vid. lo que expuesto en MARTÍNEZ-BUJÁN, P.G., $5^{\text {a }}$ ed., pp. 625 ss., donde se acoge la solución propuesta en nuestra doctrina por PEÑARANDA, 1990, pp. 355 ss., 2008, pp. 1425 y 1450 ss., 2014, p. 343, que, por lo demás, comporta la posibilidad de aplicar el art. 65-3 (por analogía, si se entiende que esta regla va solo directamente referida a los delitos especiales propios) al partícipe extraneus. Vid., sin embargo, COBO/VIVES, P.G., $5^{\text {a }}$ ed., p. 751, para quienes la autoría mediata del extraneus, valiéndose de un intraneus, provocará la aplicación de la figura básica. 
amplio sector doctrinal considera que el extraneus podría ser castigado como autor a través del delito común correspondiente, con lo que no surgiría aquí una auténtica laguna de punibili$\operatorname{dad}^{150}$. Con todo, la solución aquí propuesta, permite castigar de modo más adecuado la conducta del extraneus, dado que su castigo se articulará a partir de sanción prevista para el intraneus (que siempre es más grave) y podrá recibir incluso, por tanto, al ser inductor o cooperador necesario, la misma pena que recibiría el intraneus ${ }^{151}$.

En el caso de los denominados delitos de propia mano, en los que el legislador vincula la cualidad de autor a la ejecución inmediata y personal de la acción definida en el tipo penal, hay también una amplia coincidencia (por más que algunos penalistas discutan la propia existencia de esta categoría ${ }^{152}$ ) a la hora de entender que no es posible la autoría mediata ${ }^{153}$, por lo que el sistema derivado de la concepción significativa permitirá eludir las posibles lagunas de punición.

150 Vid. por todos, con indicaciones, HERNÁNDEZ PLASENCIA, 1996, pp. 307 s. y 358.

151 Recuérdese que la regla del art. 65-3 CP es potestativa para el tribunal.

152 Vid. por todos MAQUEDA, 1992, pp. 110 ss.; Vid. también, de forma matizada, HERNÁNDEZ PLASENCIA, 1996, pp. 299 ss., para quien "la mayoría de los delitos que hoy se reconducen a la categoría de los de propia mano son susceptibles de una comisión mediata, principalmente por la razón de que su naturaleza de propia mano no está fundamentada satisfactoriamente". En este sentido se orientan asimismo algunas sentencias del TS. En la doctrina alemana vid., por todos, indicaciones en ROXIN, A.T., II, § 25/308, donde recoge las opiniones que niegan su existencia, amén de la suya propia ( $\$ 25 / 297$ ss.), la cual comporta admitir tal categoría, por más que lo haga de un modo bastante restrictivo.

Ni que decir tiene que, con arreglo a la concepción significativa, habrá que descartar todas aquellas fundamentaciones de la autoría mediata que se basan en la idea básica del dominio del hecho y arguyen que la autoría mediata del sujeto de atrás se cimenta en el dominio sobre la realización de propia mano. Vid. lo que expongo infra dos notas más abajo.

153 Vid. por todos GIMBERNAT, 1966, pp. 242 ss.; COBO/VIVES, P.G., $5^{\text {a }}$ ed., p. 750; CEREZO, P.G., III, p. 219; MIR, P.G., L.14/78; LUZÓN, P.G., L.12/33; DÍAZ G.-CONLLEDO, 1996, p. 1285, 2001, p. 51, y 2004, p. 53; DÍEZ RIPOLLÉS, P.G., 4ª ed., p. 372. 
Con todo, antes de explicar el porqué de tal elusión, me interesa aclarar que, sin negar lo discutible que nos pueda parecer la existencia de los delitos de propia mano, lo cierto es que es el legislador el que, sin asomo de dudas a mi juicio, reconoce que en algunos delitos la conducta solo se puede realizar personalmente, sin intermediarios (con lo que solo entonces concurrirá el específico desvalor de acción de la conducta) ${ }^{154}$, como sucede en unos de los ejemplos más característicos en el ámbito de los delitos contra la libertad sexual que exigen un contacto corporal $^{155}$. Ello me parece especialmente claro en uno de los

154 Vid. por todos ROXIN, A.T., II, § 25/308, exponiendo los ejemplos existentes en el vigente StGB, por más que ello no lo considere político-criminalmente acertado.

Y ello se ve reforzado, desde luego, a partir de las premisas de la concepción significativa que aquí se acoge, en la medida en que negar la existencia de delitos de propia mano y, consiguientemente, admitir la autoría mediata de la persona que no realiza directo-corporalmente la acción supondría vulnerar el principio de legalidad, al prescindirse de un elemento específico del tipo penal.

Con relación a esto último me parecen plenamente compartibles las afirmaciones de DÍAZ G.-CONLLEDO (1991, p. 523, n. 342), cuando, al examinar la estructura de la autoría mediata y aludir al requisito de la concurrencia de los elementos personales, entiende que en los delitos de propia mano el legislador ha redactado el tipo ("aunque lo haya hecho de modo equivocado", por no existir una razón material que lo justifique) de una manera tal que la conducta solo se puede realizar directo-corporalmente " $y$, por tanto, ante sus palabras todo otro tipo de consideraciones sobran (elemento puramente formal)".

155 Vid. por todos MIR, P.G., L.9/52, CEREZO, P.G., III, p. 219. Otros ejemplos son: la bigamia (art. 217), los delitos contra la seguridad vial que consisten en conducir (art. 379 ss.) o los delitos de falso testimonio (arts. 458 ss.). En referencia al StGB cita ROXIN (A.T., II, § 25/297 ss.) además: el incesto y determinados delitos reconducibles a un Derecho penal de autor, como la rufianería o el proxenetismo; y, a mayores, incluye los delitos de prevaricación (judicial, administrativa o de árbitro) y de deserción, como delitos de propia mano "impropios", por basarse en la infracción de deberes altamente personales.

En su trabajo destinado específicamente a la autoría mediata, menciona DÍAZ G.-CONLLEDO (2001, p. 55) el ejemplo del delito publicitario del art. $282 \mathrm{CP}$, al referirse a los "problemas específicos de autoría mediata" que se plantean cuando se trata de "delitos socioeconómicos de propia mano o 
casos más frecuentemente citados, esto es, el caso del tipo cualificado consistente en el acceso carnal ${ }^{156}$, pero también me lo parece en los tipos básicos de los delitos de agresión y abusos,

con modalidades limitadas de acción o cuando se trate de delito especiales". $\mathrm{Y}$, aunque en principio parece que se refiere a este delito únicamente como ejemplo de delito especial -"los problemas más graves de autoría en este tipo no se dan por la restricción de las modalidades de acción, sino más bien por la restricción del círculo de posibles autores (delito especial) ... en cuanto que será imposible hacer responder como autores, por no ser fabricantes ni comerciantes, a sujetos distintos de los mencionados ... (publicistas, asesores, etc.)"-, a renglón seguido, con relación a este mismo delito, añade que "no aceptándose la posible fundamentación de la autoría mediata en el dominio sobre la actuación de propia mano de otro o sobre los medios limitados de ejecución que otro emplea ..., pueden producirse en los ámbitos señalados algunas dificultades o incluso lagunas de punición" (p. 56).

Con independencia del sentido de las consideraciones de DÍAZ, en lo que atañe al delito del art. 282 están claras, a mi juicio, dos cuestiones. Por un lado, no contiene un delito de propia mano (porque no exige que la acción sea realizada directo-corporalmente por los fabricantes o comerciantes), sino un delito especial (o, mejor dicho, un "delito doblemente especial", porque el círculo de sujetos activos no solo aparece restringido a los "fabricantes o comerciantes", sino que además aparece ulteriormente concretado por el dato de que las alegaciones falsas deben recaer sobre "sus" productos o servicios, lo que excluye del círculo de sujetos idóneos a las agencias publicitarias, dado que, aun siendo comerciantes, estas no alegan falsamente sobre "sus" productos), y, en particular, un delito especial de los usualmente denominados "de dominio social" (o "de posición"), sin ningún elemento de infracción de deber. Por otro lado, en atención a ello, no observo problema alguno a la hora de determinar la autoría: habrá un supuesto evidente de autoría mediata cuando la agencia de publicidad elabore la comunicación falsa con base en los datos falsos proporcionados por el anunciante, ignorando tal circunstancia (sería un caso de un instrumento que obra en situación de error sobre el tipo); podrá haber una autoría de la agencia de publicidad, por la vía de la actuación en lugar de otro (ex art. $31 \mathrm{CP}$ ), cuando sea ella la que ha elaborado el mensaje falso; podrá incluso haber una coautoría en supuestos de co-ejecución entre el anunciante y la agencia (vid. PUENTE ABA, 2001, pp. 382 ss.).

156 Vid. por todos LUZÓN, P.G., L.12/33.

Es preciso subrayar que, sin entrar en consideraciones materiales, existe una insoslayable razón formal (vinculada, pues, al principio de legalidad) que impide castigar (como autor mediato) a quien no realiza inmediata o personalmente la conducta típica de "acceder carnalmente". Y ello deviene especialmente ineluctable desde la perspectiva de la concepción significativa, en 
que exigen que el sujeto activo "atente contra la libertad (o indemnidad) sexual de otra persona"157.

Aclarado lo que antecede, y reconocida de lege lata la existencia de delitos de propia mano en el vigente CP español, la utilidad del sistema que se deriva de la concepción significativa se constata en el hecho de que, si bien el sujeto de atrás no podrá ser autor mediato, sí podrá en cambio ser castigado como partícipe.

la que la interpretación gramatical (efectuada conforme al lenguaje común y, por tanto, tomando como base y límite infranqueable el diccionario de la RAE) no admite otra exégesis que no sea la de considerar que es, v. gr., el sujeto activo del tipo del art. 179 el único que ha de tener el acceso carnal con la víctima, en virtud de lo cual no tiene acceso carnal "quien pone una pistola en la sien de otra persona obligándole bajo amenaza de muerte a penetrar a o a ser penetrada por una tercera persona, o quien engaña a otro (incluso de manera invencible) sobre el consentimiento en la penetración vaginal, anal o bucal por quien aparentemente se resiste a él". Tomo este ejemplo de DÍAZ G.-CONLLEDO (2001, p. 52), con la particularidad de que, si bien este penalista lo consideraba un claro ejemplo bajo la vigencia de la regulación del CP 1944/1973, ha mostrado después sus dudas con relación al vigente art. 179 del nuevo CP 1995, con el argumento de que la redacción actual "permite interpretar que no es necesario que quien atenta contra la libertad sexual de otro existiendo un acceso carnal o introducción de objetos sea el mismo que realiza tal acceso o introducción, y, en consecuencia, que cabe la autoría mediata en este delito".

Sin embargo, frente a estas dudas de DÍAZ, no observo en este concreto aspecto cambio sustancial alguno en la redacción del tradicional tipo de violación: antes se indicaba que cometía violación "el que tuviere acceso carnal con otra persona" y ahora se señala -leyendo los arts. 178 y 179 de forma integrada o completa- que comete violación el que "atenta contra la libertad sexual de otra persona de un manera que consista en un acceso carnal".

Eso sí, no es un delito de propia mano el $\S 177$ StGB porque prevé expresamente que el acceso carnal sea practicado con el autor o "con un tercero". Vid. ROXIN, A.T., II, § 25/289, n. 381.

157 En el supuesto del art. 178 DÍAZ G.-CONLLEDO (ibid.) entiende, sin vacilaciones, que "ya no se tipifican delitos de propia mano, pues se habla de 'atentar contra la libertad de otra persona, con violencia o intimidación'". No obstante, lo que, en rigor, nos dice el art. 178 es que sujeto activo del tipo es únicamente "el sujeto que" atenta (o sea, "ejecuta algo ilegal o ilícito", en la acepción del Diccionario de la RAE aquí aplicable) contra la libertad sexual, de tal modo que no creo que pueda interpretarse que, v. gr., quien pone 
Así, tomando prestado el ejemplo del abuso sexual con prevalimiento (art. 181-3) que propone DÍEZ RIPOLLÉS, cabe concluir que la concepción significativa permite castigar a la persona de atrás como partícipe en el caso de que esta sea la persona que cumple el elemento del prevalimiento mientras que la conducta sexual es realizada por un instrumento ignorante de que su pareja está sometida a presiones. A juicio de dicho penalista (y de la opinión dominante) la conducta es atípica: “el instrumento no realiza una conducta típica, por creer que hay consentimiento libre de su pareja, y la persona de atrás no es autora mediata

una pistola en la sien de otra persona obligándola bajo amenaza de muerte a penetrar a o a ser penetrada por una tercera persona está ejecutando/realizando la agresión sexual: lo que está haciendo es obligando a otro a que este realice la agresión sexual, consista esta en acceso carnal o en cualquier otra clase de agresión sexual.

En suma, entiendo que el delito de agresión sexual (y también el delito de abuso sexual) exige la presencia de un contacto corporal entre el sujeto activo del tipo y la víctima, quedando excluidos los supuestos en los que un sujeto obliga a un tercero a realizar un contacto corporal con la víctima (o el supuesto materialmente equivalente de obligar a la propia víctima a realizar el contacto corporal con el tercero). Y esta interpretación se ha visto corroborada tras la reforma de 2015, dado que el nuevo art. 183-2 incluye expresamente esta última conducta como una agresión sexual en el caso de menores de 16 años ("a participar en actos de naturaleza sexual con un terceo"), con lo que a contrario sensu hay que interpretar que el legislador no considera dicha conducta como una agresión sexual del art. 178 en el caso de mayores de 16 años. Y por idéntico razonamiento a contrario sensu hay que entender también que queda excluida del art. 178 la conducta del sujeto que determina a la víctima a realizar contactos corporales sobre sí misma, habida cuenta de que en el citado art. 183-2 se prevé expresamente esta conducta ("o a realizarlos sobre sí mismo") como agresión sexual a menores de 16 años. Por lo demás, esta exégesis es coherente con el tratamiento del caso (relatado anteriormente) del sujeto que se limita a llevar a cabo la violencia o intimidación para que un tercero (plenamente libre y responsable) pueda agredir sexualmente a la víctima: dicho sujeto no puede ser nunca autor del acceso carnal, solo partícipe; autor será únicamente el que acceda carnalmente. Y repárese en que en este caso no existe problema alguno desde el punto de vista del principio de legalidad para castigar a este tercero, aunque él no hubiese aplicado de propia mano la fuerza: es incuestionable que este sujeto atenta contra la libertad sexual de la víctima "utilizando la violencia o intimidación", puesto que el Diccionario de la RAE admite que "utilizar" consista en "aprovecharse de algo o de alguien". 
pues no puede realizar la acción sexual por intermedio del instrumento" 158 . Sin embargo, con arreglo a los presupuestos de la concepción significativa llegamos a la siguiente conclusión: la persona de atrás no puede, ciertamente, ser autora mediata porque no realiza directo-corporalmente la acción sexual, pero el instrumento sí realiza una conducta típica (relevante y ofensiva) al llevar a cabo la acción sexual. El instrumento obra en una situación de error personal (o subjetivo) sobre un elemento del tipo de acción (esto es, el elemento del consentimiento libre), situación que le exime personalmente de responsabilidad penal por ausencia de ilicitud (segunda categoría del delito), pero que deja subsistente el tipo de acción, de tal manera que la persona de atrás, que no incurre en dicho error, puede ser castigada como partícipe en la conducta típica realizada por el instrumento, que es autor en el sentido lógico-gramatical que aquí nos interesa.

Por lo demás, algo similar, mutatis mutandis, cabe predicar del caso de los delitos con medios legalmente determinados (o, mejor, con modalidades tasadas o limitadas de acción) en los que, según un importante sector doctrinal ${ }^{159}$, tampoco cabe la autoría mediata, so pena de vulnerar el principio de legalidad ${ }^{160}$.

158 DÍEZ RIPOLLÉS, P.G., $4^{\mathrm{a}}$ ed., p. 372, quien alude también a otros posibles ejemplos en los casos de los delitos tipificados en los arts. 217 y 379.

159 Vid. por todos ya GIMBERNAT, 1966, pp. 224 ss.; vid. también DÍAZ G.CONLLEDO, 1991, pp. 174, 468 ss. y n. 193; 1996, p. 1285; 2004, p. 53. Ello no obstante, hay que reconocer que otro sector no descarta tal posibilidad: vid. por todos COBO/VIVES, P.G., p. 751, QUINTERO, 1974, p. 110; CEREZO, P.G., III, p. 219, HERNÁNDEZ PLASENCIA, 1996, p. 280, quienes arguyen que carece de fundamento excluir la autoría mediata, dado que el autor mediato puede, a través del instrumento, realizar la conducta, partiendo de un entendimiento amplio del concepto de ejecución que permita una realización no solo del resultado, sino también de la acción.

160 En sentido coincidente con lo que expongo, vid., especialmente, DÍAZ G.CONLLEDO, 2001, p. 51, quien considera además como similares los supuestos de delitos de propia mano y delitos con modalidades limitadas de acción. Por lo demás, nuevamente hay que añadir aquí que, con arreglo a la concepción significativa, habrá que descartar todas aquellas fundamentaciones de la autoría mediata que se basan en la idea básica del dominio del hecho y arguyen que la autoría mediata del sujeto de atrás se cimenta en el dominio sobre la realización de los medios o modalidades limitadas de acción. 
Ahora bien, de nuevo hay que matizar que ello no significa que la exclusión de la autoría mediata nos aboque a una laguna de punibilidad. En efecto, con arreglo al sistema de la concepción significativa, bastará con que la persona de delante realice un tipo de acción objetivamente relevante y ofensivo (v. gr., el del robo con fuerza en las cosas del art. $238 \mathrm{CP}$ ) para que la persona de atrás pueda ser castigada como partícipe en dicha conducta, con independencia de que la persona que realiza inmediatamente el tipo pueda quedar exenta de responsabilidad penal por incurrir en una situación de error personal sobre el tipo o por actuar al amparo de una causa de justificación.

Y conviene subrayar que la evitación de la laguna de punibilidad únicamente puede venir fundamentada en la adopción del criterio de la accesoriedad mínima objetiva, al que conduce la concepción significativa, y no, en cambio, en la acogida del criterio de la accesoridad limitada o incluso el de la accesoriedad mínima subjetiva, pese a que, en ocasiones, algunos penalistas hayan sostenido lo contrario ${ }^{161}$.

Así las cosas, y para finalizar este apartado, a todo lo que antecede cabe añadir todavía que, más allá de los tres casos hasta aquí examinados (reconocidos por la opinión mayoritaria como supuestos en los que la autoría mediata queda vedada), la utilidad de la caracterización que aquí acojo será todavía mayor a

161 Así, con respecto a esto último, cabe mencionar la opinión de GIMBERNAT (1966, pp. 224 s.), quien, tras reconocer la dificultad de admitir una autoría mediata en los delitos de resultado con modalidades limitadas de acción, aduce (expresado de modo muy sintético) que la cuestión no posee mayor relevancia desde el punto de vista de la justicia material, dado que, al existir un ejecutor inmediato, la conducta de la persona de atrás puede ser castigada a través de las figuras de inducción o de la cooperación necesaria. Sin embargo, frente a esta posición ha objetado, con razón, DÍAZ G.-CONLLEDO (1991, pp. 469 s., n. 193) que (expresado también de forma muy sintética), a partir de la concepción sistemática que mantienen ambos penalistas, el principio de la accesoriedad limitada se opone al castigo de la participación cuando el ejecutor inmediato ha obrado sin dolo o imprudencia o ha actuado al amparo de una causa de justificación. 
medida que vaya entendiéndose que existen otros supuestos en los que la autoría mediata tampoco es factible.

Y así sucede singularmente en el (más arriba citado) ${ }^{162}$ caso de que la persona de delante realice un delito imprudente, por obrar en una situación de error vencible sobre el tipo, en tanto que la persona de atrás es plenamente consciente de la situación. Ciertamente, la opinión mayoritaria no ve inconveniente en admitir la autoría mediata dolosa en este caso, por lo que castiga al instrumento como autor inmediato del delito imprudente y a la persona de atrás como autora mediata de un delito doloso $^{163}$. Sin embargo, esta posición no es unánime y existe un cualificado sector doctrinal (al que me he adherido) que considera que la autoría mediata no es factible cuando el instrumento es penalmente responsable. Pues bien, situados entonces ante esta última hipótesis, el sistema de la concepción significativa (basado en el criterio de la accesoriedad mínima objetiva) va a permitir, coherentemente, que pueda ser exigida la responsabilidad penal de la persona de atrás como partícipe de un delito doloso, aunque la persona de delante haya obrado con imprudencia ${ }^{164}$, posibilitando así eludir la insatisfactoria consecuencia (a la que abocaría el mantenimiento de la concepción dominante de la accesoriedad subjetiva) de considerar que la responsabi-

162 Vid. supra 3.2.2.1.

163 Vid. por todos DÍAZ G.-CONLLEDO, 2001, p. 35; 2007, p. 135; 2017, p. 516. Recuérdese que también DÍEZ RIPOLLÉS (P.G., p. 368) llega a la misma conclusión a partir de otra caracterización de la autoría mediata.

164 Vid. MARTÍNEZ-BUJÁN, 2013, pp. 110 ss. La razón estriba en que la conducta del partícipe debe tomar como base únicamente la realización de un tipo de acción ofensivo para un bien jurídico penal (pretensión de relevancia); y ello con independencia de la intención subjetiva que rige la conducta del autor, puesto que esta pertenece a una pretensión diferente (la pretensión de ilicitud) en la que se dilucida el momento de la infracción de la directiva de conducta contenida en la norma. A idéntica conclusión llega ROBLES (2003, p. 224), a partir de una diferente concepción sistemática, sobre la base de su caracterización de la accesoriedad como nexo normativo suficiente que debe concurrir entre la conducta del interviniente y el "hecho" típico. 
lidad de la persona de atrás (que ha obrado dolosamente) sea calificada como participación en el delito imprudente cometido por la persona de delante y a partir de este marco penal típico ${ }^{165}$.

\subsection{El caso del sedicente instrumento doloso no cua- lificado}

Finalmente, existe un supuesto en el que, en principio, pudiera parecer que las consecuencias sistemáticas a las que aboca la concepción significativa coinciden con las obtenidas por las concepciones dominantes (basadas en el criterio de la accesoriedad limitada), y, por tanto, que prima facie estamos ante un caso en el que podría desembocarse en la impunidad de la conducta: me refiero al supuesto del llamado instrumento doloso no cualificado, en el que la persona de atrás (intraneus) utiliza a un extraneus para realizar el sustrato material del tipo de acción o, si se prefiere, su base fáctica (el tipo de acción no lo puede realizar porque no es un sujeto idóneo) ${ }^{166}$, supuesto en el que la

165 Vid., por todos, como posición paradigmática de la opinión mayoritaria, MIR, P.G., L.15/37, exigiendo inexcusablemente el dolo en el autor principal para poder castigar la participación dolosa (en cuanto tal, o sea referida a un tipo doloso).

Sin embargo, repárese en que no deja de ser un contrasentido que, en el planteamiento de la opinión mayoritaria, aquellos que, como MIR, admiten el castigo de la participación imprudente tengan que concluir que, si se interviene en un hecho principal imprudente, se castigue con la misma pena al partícipe que obra con dolo y al partícipe que actúa con imprudencia.

166 En el seno del CP español se suelen citar como ejemplos los siguientes: en el caso de los delitos especiales propios genuinos (con un elemento de infracción de deber), el ya mencionado supuesto del "funcionario que hace destruir a su secretaria particular unos papeles confiados a aquél por razón de su cargo", con respecto al cual el art. 413 restringe la cualidad de autor al funcionario o autoridad (vid. MIR, P.G., L.14/52; vid. también DÍEZ RIPOLLÉS, P.G., p. 371); en el caso de los delitos especiales propios denominados "de posición" (que no exigen entre sus elementos la infracción de un deber) el ejemplo del deudor que ordena a un subordinado ocultar los bienes de aquél para perjudicar a los acreedores (Vid. MARTÍNEZ-BUJÁN, P.E., p. 76.).

Obviamente, el problema se puede plantear también en los denominados delitos especiales impropios, mas en este caso la cuestión posee menos relevancia, como indico en la nota siguiente. 
opinión dominante considera que no cabe la autoría mediata del sujeto de atrás intraneus ${ }^{167}$, habida cuenta de que -se afirmael sujeto de delante actúa libremente y con conocimiento de la situación, y, por supuesto, sin que el intraneus hubiese contribuido a realizar el hecho conjuntamente con el extraneus ${ }^{168}$; por su parte, a la persona de delante le falta la especial cualidad de autoría exigida por el tipo de acción (por lo que ni siquiera con el criterio de la accesoriedad mínima objetiva podría ser considerado autor) y, por tanto, en su conducta atípica no cabría una participación punible ${ }^{169}$.

Sin embargo, creo que, frente a esta opinión dominante, cabe efectuar algunas matizaciones tendentes a poder fundamentar la punibilidad de la conducta, sin que ello implique asumir la tesis general de los delitos de infracción de deber al

167 Vid. por todos ya GIMBERNAT, 1966, pp. 261 ss., RODRÍGUEZ MOURULLO, 1969, pp. 469 ss. Vid. además, entre otros, DÍAZ G.-CONLLEDO, 1991, pp. 618 ss., 647 y 730, n. 49; DÍEZ RIPOLLÉS, 1998, p. 52 y n. 85 ; entiendo que, obviamente, también se refieren a este supuesto ORTS/G. CUSSAC, P.G., 2017, p. 316, cuando afirman que "tampoco es posible articular la autoría mediata en delitos especiales entre el autor idóneo (intraneus) ... que instrumentaliza al tercero inidóneo (extraneus)".

Por tanto, ello conduciría a la total impunidad en el caso de los delitos especiales propios y a castigar por el delito común en el caso de los especiales impropios. De ahí que suela afirmarse que en estos últimos delitos la cuestión "será importante, pero no de importancia decisiva, pues al menos es seguro que al intraneus se le podrá castigar como inductor del delito común correspondiente, del que es autor inmediato el extraneus" (cfr. DÍAZ G.CONLLEDO, 2001, p. 44).

168 En esta última hipótesis no habría inconveniente alguno en caracterizar al intraneus como auténtico coautor (inmediato), en la medida en que él contribuya a realizar/ejecutar el hecho típico (en el ejemplo citado más arriba, imaginemos que el funcionario lleva a cabo conjuntamente con un extraneus la destrucción de los papeles confiados a aquel por razón de su cargo), sin que a ello sea obstáculo que no exista otro coautor (porque el extraneus no puede serlo, al carecer de la cualidad personal, y, por tanto, será solo cooperador necesario). Vid. por todos DÍEZ, 1998, p. 53, con indicaciones bibliográficas.

169 Vid. indicaciones, por todos, en MIR, L.14/59 n. 46; DÍEZ RIPOLLÉS, P.G., p. 371. 
estilo de los Pflichtdelikte de ROXIN, en los que resulta indiferente que el sujeto vinculado por el deber lo infrinja actuando de propia mano o convenciendo a otro para que este realice la conducta de la que se deriva la infracción del deber, tesis que aquí he rechazado ${ }^{170}$.

Así, en primer lugar, entiendo que debe compartirse con MIR la atinada observación de que el rechazo de la autoría mediata es comprensible si se parte de la premisa de una concepción de la autoría basada en un dominio del hecho entendido como "control del hecho"171. Pero tal rechazo se ve desvirtuado si no se acoge semejante concepción de la autoría, por lo que queda expedita la vía para apreciar la autoría mediata de la persona de atrás: tanto si se adopta una versión del dominio del hecho diferente a la del control del hecho ${ }^{172}$, como (sobre todo) si se prescinde completamente, como aquí se hace, de la idea del dominio del hecho como criterio rector.

170 En esta tesitura el intraneus sería siempre autor (a mi juicio, ya no necesariamente autor mediato) porque ha infringido el deber, por más que lo haya hecho mediante la inducción a un extraneus para que este realice la conducta de la que se deriva la infracción del deber: el extraneus, por su parte, podrá ser castigado como partícipe

Sin embargo, la opinión dominante en España (desde la crítica efectuada por GIMBERNAT) viene rechazando con carácter general la construcción de ROXIN para fundamentar una autoría mediata del sujeto de atrás. Vid., por todos, DÍAZ G.-CONLLEDO, 2001, p. 46, y 2018, p. 170. Vid. también, rechazando la construcción de ROXIN al hilo del estudio de la autoría mediata, HERNÁNDEZ PLASENCIA, 1996, pp. 314 ss., con indicaciones.

171 Vid. paradigmáticamente, por todos, CEREZO, P.G., III, p. 216, invocando el argumento de que en estos casos no concurre el genuino dominio del hecho ("en estos caso sólo podría hablarse de un dominio del hecho en un sentido puramente normativo"). Y, así, efectivamente, cabe asegurar (como escribe MIR, L.14/59) que en el referido ejemplo del art. 413, "la influencia del funcionario en la producción fáctica del hecho no es mayor, en términos de control del hecho, por la circunstancia de que el mediador no sea también funcionario. Desde el prisma del control del hecho, el papel del funcionario de atrás es el mismo. ¿Por qué considerarle 'inductor' si el mediador es un sujeto cualificado (funcionario) y, en cambio, 'autor mediato' si no lo es?'”

172 Vid. MIR, L.14/60-61, donde admite la autoría mediata en este supuesto desde su concepción de la autoría como relación de pertenencia del delito, 
Así las cosas, desde la perspectiva de la concepción significativa no solo cabe acoger sin reservas esta observación sino que cabría ir más allá y afirmar que, en rigor, y de modo análogo (aunque no idéntico) a lo que sucedía en el llamado "instrumento doloso sin intención", es ya conceptualmente incorrecto hablar de un "instrumento doloso no cualificado": y es que, en efecto, si el sujeto obra sin poseer la especial cualidad de autoría requerida por la correspondiente figura de delito, no realiza ya siquiera el tipo de acción de ese delito, sino solo el sustrato material del tipo, y, por tanto, carece de todo sentido afirmar que obra con dolo, por mucho que conozca y quiera realizar los restantes elementos del tipo. No existe ya el primer y básico elemento del delito, el tipo de acción, en la conducta del instrumento, por lo que ni siquiera se cumple la primera pretensión de validez (la de relevancia) de la norma penal.

Ciertamente, hay una diferencia de sentido con el caso del denominado "instrumento doloso sin intención": en este el sujeto desconoce el significado típico de su conducta, dado que la concurrencia del especial elemento subjetivo del tipo se erige

una relación "que concurre en el sujeto causante del mismo al que puede y debe imputársele (el delito no solo su realización fáctica) como suyo porque ningún otro sujeto se halla en mejor situación para disputárselo". Añade MIR a renglón seguido que en los dos casos acabados de comparar (vid. la nota anterior) "el funcionario de atrás es causa del hecho -sin él no se hubiera producido la actuación del mediador- el hecho constituye realización del riesgo típicamente relevante que supone la conducta del funcionario (imputación objetiva del resultado): ello constituye una base objetiva suficiente para imputar a éste el delito como autor si otro sujeto, el mediador, no puede serlo". Por lo demás, si bien MIR nada dice acerca de la responsabilidad del instrumento, parece que no habría obstáculo para castigarlo entonces como como cooperador necesario, dado que, aunque ciertamente es extraneus, ningún obstáculo existiría (según indico más abajo) para sancionarlo como partícipe en el delito especial (con la posible rebaja prevista en el art. 65-3 CP).

Con todo, este razonamiento de MIR, que ha sido calificado de "muy interesante" y "sugerente", (vid. DÍAZ G.-CONLLEDO, 1991, pp. 615 ss.) se considera "insuficiente", si no se acepta, con carácter general, la idea de la pertenencia como criterio para la determinación de la autoría (cfr. DÍAZ G.-CONLLEDO, 2001, p. 45). 
en requisito imprescindible para comprender el sentido de la acción (pertenece al propio concepto de la acción), por lo que su ausencia no solo impide el nacimiento del tipo de acción, sino que convierte al sujeto de delante en un verdadero instrumento "ciego" a los efectos de apreciar la autoría mediata del sujeto de atrás; en cambio, en el caso genuino del "instrumento doloso no cualificado" el sujeto de delante obra con pleno conocimiento del significado penalmente típico de su conducta, porque, al conocer todos los términos típicos de la figura de delito, interpreta correctamente el sentido típico de su acción, siendo así que lo único que falta para que su conducta cumpla el tipo de acción es la concurrencia en él de la cualidad personal de autoría. De ahí que, si bien no quepa afirmar que obra con el dolo típico (insisto, por la sencilla razón de que no hay tipo), sí pueda asegurarse que actúa con pleno conocimiento de la situación fáctica, esto es, sabiendo que está realizando el sustrato fáctico de una conducta que integraría un tipo penal si en él concurriese la cualidad de autoría o si dicha conducta hubiese sido ejecutada de propia mano por el sujeto cualificado que le convenció para actuar. Y, por supuesto, además de lo anterior, es un sujeto que actúa con plena libertad (sin coacción de ninguna clase). En resumen, desde la perspectiva de la concepción significativa, si bien es cierto que no cabe hablar de un "instrumento doloso no cualificado", sí cabría aludir a un "instrumento no cualificado que sabe que su conducta realiza el sustrato fáctico de un tipo penal, el cual se integraría plenamente si concurriese en él la cualidad de autoría o si la conducta hubiese sido ejecutada de propia mano por el sujeto que lo convenció para llevar a cabo la materialidad de la acción típica".

Conforme a este punto de vista, pudiera pensarse que admitir la autoría mediata no se acompasaría bien con el fundamento que la opinión mayoritaria invoca para poder hablar de una autoría mediata, esto es, que la persona de atrás se sirva de la de delante como un auténtico instrumento "ciego" (debido a coacción, a error o a una situación de real inimputabilidad), o, según la caracterización propuesta por VIVES, que la persona 
de atrás se sirva de la de delante de un modo equivalente a la utilización de un animal o de una fuerza de la naturaleza ${ }^{173}$.

Ello no obstante, creo que, aun aceptando la apuntada diferencia de sentido, no debería existir objeción para admitir la autoría mediata de la persona de atrás, a la que incumbe el deber, cuando se sirve de otra persona que realiza solo el sustrato material del tipo (por no poseer la cualidad personal de autoría) ${ }^{174}$, sobre la base de entender que lo verdaderamente decisivo para ello es que el mediador no pueda ya ser autor en el sentido lógicogramatical. Es más, según indiqué supra al caracterizar la figura del instrumento, la naturaleza de la autoría mediata como auténtica autoría se pone de manifiesto precisamente en este caso, en el que solo existe un autor (incluso, en el más básico de los sentidos, el lógico-gramatical), que es el autor mediato, con lo que, por cierto y por lo pronto, se cumple la premisa restrictiva más arriba apuntada para la existencia de una autoría mediata: la persona de delante es, en sí misma, penalmente irresponsable del tipo de acción cuyo sustrato fáctico realiza.

Desde luego, trasladando la cuestión al Derecho español, hay que señalar que el tenor literal del art. 28 del CP no es obstáculo a este entendimiento, puesto que en los casos en comentario el sujeto cualificado "se sirve de otro" (un sujeto no cualificado) como un genuino instrumento (que eso sí, aquí sería "vidente", y no ciego), en la medida en que este solo puede realizar la mera materialidad de la acción típica porque conceptualmente nunca podrá ser autor.

173 Con todo, recuérdese que VIVES también compartía la idea, más arriba expuesta y sobre la que vuelvo a continuación en el texto, de que la naturaleza de la autoría mediata como auténtica autoría se pone de manifiesto precisamente en este caso, en el que solo existe un autor (incluso, en el más básico de los sentidos, el lógico-gramatical), que es el autor mediato (cfr. $\mathrm{COBO} /$ VIVES, P.G., p. 748, si bien su apreciación va referida a la realización de un "injusto típico").

174 Recuérdese que, en la línea que aquí mantengo, para MIR (MIR, L.14/58) la autoría mediata debería admitirse asimismo en todos los casos de "falta de concurrencia de la parte objetiva del tipo". 
Y a esta interpretación de los términos empleados por el legislador para definir la autoría mediata no cabría oponer que también en todos los casos de inducción el inductor se estaría sirviendo del inducido como un instrumento para que este realizase el delito que aquél quería que se cometiese. En efecto, a esto cabe responder, a su vez, que entre ambos supuestos media una diferencia trascendental con arreglo a las premisas que aquí asumo $^{175}$. En los casos de inducción la persona de delante realiza siempre el tipo de acción y, además (aquí sí), obra con el dolo típico, en virtud de lo cual se convierte en el sujeto central (gramatical y valorativamente) del acontecimiento delictivo; y ello comporta ineluctablemente que, al reunir este todas las características de la autoría, se erija en el único autor (en el sentido lógico-gramatical y en el sentido personal) del hecho realizado, desplazando de esa posición (como posible autor mediato) a la persona de atrás, inductor, el cual, por definición, no ha realizado/ejecutado de propia mano acción típica alguna, sino que solo ha llevado a cabo una conducta de participación en la conducta realizada por el inducido. En los casos que aquí examinamos, empero, la persona de delante ni siquiera puede ser autor en sentido lógico-gramatical (no realiza ya un tipo de acción), con lo que, incluso partiendo del criterio de la accesoriedad mínima objetiva que aquí se acoge, en dicha conducta no cabrá admitir una participación punible.

En suma, hay que reconocer que en el supuesto que analizamos no hay duda de que materialmente lo que el instrumento lleva a cabo es una conducta de participación (cooperación necesaria o complicidad) en un tipo penal, pero se trata de una conducta que, a la postre, solo podrá ser efectivamente castigada (en virtud de los arts. 28 y $29 \mathrm{CP}$ ) si existe un autor al que atribuir la realización de ese tipo.

175 Cuestión diferente, obviamente, sería que -como indiqué más arriba acogiendo el razonamiento de MIR- partiésemos de una caracterización de la autoría concebida como control del hecho. En tal caso, el grado de dominio o influencia en la producción fáctica del hecho de la persona cualificada sobre la no cualificada es exactamente el mismo que poseería si el mediador fuese una persona cualificada. 
Eso sí, dogmáticamente nos encontraríamos entonces ante algo aparentemente contradictorio: por una parte, un instrumento que resultaría penalmente irresponsable desde el punto de vista de la calificación como autoría (que recaería exclusivamente en el sujeto de atrás a título de autor mediato); por otra parte, un instrumento que sería responsable a título de partícipe por su contribución a una conducta de autoría en la que él ha llevado a cabo el sustrato material del tipo.

Ello no obstante, la referida contradicción se desvanece si reparamos en que nada debería objetarse a que la contribución fáctica realizada por el sujeto de delante no cualificado (v. gr., destruir un documento) sea, por un lado, insuficiente para fundamentar su propia autoría, pero sea relevante para contribuir a una autoría ajena, la del sujeto cualificado. El único tipo de acción que se ha realizado en la realidad es el que ejecuta el autor mediato (v. gr., el del art. 413), por más que la acción se lleve a cabo a través de un instrumento que meramente realiza el sustrato fáctico de dicho tipo, en atención a lo cual nunca se estará ante la hipótesis de un autor detrás del autor (ni siquiera en sentido lógico-gramatical). Y si lo anterior es certero, ningún problema habrá para admitir que la contribución del sujeto no cualificado favorece la realización del tipo de acción que lleva a cabo otro en calidad de autor ${ }^{176}$.

176 Y repárese, una vez más, en que en este caso no puede oponerse la conocida objeción que DÍAZ G.-CONLLEDO (2001, p. 45) formula a tesis como la de MIR, esto es, la de que "no existe fundamento material alguno (más allá de la producción de una laguna de punición injustificada, y ésta no es fundamento suficiente) que explique la autoría mediata del intraneus" (vid. anteriormente 1991, p. 617). En efecto, con arreglo a la concepción significativa no nos interesa saber por qué "domina aquí el hecho el intraneus", desde el momento en que el criterio del dominio del hecho se descarta ya con carácter general como caracterizador de la autoría. Lo decisivo será saber, en cambio, si cabe interpretar que en este caso el intraneus realiza el tipo de acción de un modo estructuralmente (normativamente) equivalente al supuesto en el que él mismo lo hubiese llevado a cabo inmediatamente, o sea, utilizando al extraneus como mero instrumento a su servicio con el fin de que este realice la mera materialidad o la base fáctica del tipo de acción. 
Es más, podría suceder incluso que la mencionada contribución del instrumento fuese, a su vez, simultáneamente constitutiva de autoría de un delito diferente (como, v. gr., sucedería, en el ejemplo que vengo utilizando, con el delito del art. 416, que prevé una figura aplicable al particular), en cuyo caso lo que habría que dilucidar es si estamos ante un concurso ideal de delitos entre la participación del instrumento en el delito especial del art. 413 y su propia autoría del art. $416^{177}$ o ante un conflicto aparente de normas penales ${ }^{178}$.

En fin, a la vista de lo que antecede y regresando a la hipótesis general, se llega además a una conclusión que, sobre ser dogmáticamente correcta, resulta satisfactoria desde la perspectiva de la justicia material: al sujeto de atrás se le castigará como autor mediato y al de delante como partícipe.

Con todo, en relación con el genuino "instrumento doloso no cualificado" (tal y como lo define la opinión dominante), todavía cabría efectuar una ulterior matización en referencia a la hipótesis particular en la que el sujeto de delante hubiese llevado a cabo un comportamiento neutral o standard, que supone

177 Esta es la solución que me parece más acertada, porque si apreciamos solo el delito del art. 416 no tenemos en cuenta la contribución del no cualificado a la realización del delito del art. 413, que, según indiqué, posee una dimensión lesiva accesible al extraneus (sin perjuicio de poder rebajar la pena de este delito conforme al art. 65-3). Y si apreciamos solo la participación en el delito del art. 413, no tenemos en cuenta que el sujeto es autor directo de un delito diferente en el que entonces cabría admitir la participación de terceras personas (algo no factible si consideramos que el no cualificado es solo un partícipe en el delito del art. 413).

178 En esta segunda hipótesis el conflicto se resolvería apreciando solo la infracción más gravemente penada, que en el caso de una cooperación necesaria sería la del art. 413, porque la rebaja de la pena en grado prevista en el art. 65-3 es solo potestativa, mientras que la misma rebaja de un grado prevista en el art. 416 (para la conducta de autoría del particular) es obligatoria, y que en el caso de la complicidad sería cualquiera de las dos, porque habría que aplicar una rebaja obligatoria de un grado en ambos casos. Con todo, entiendo que en el caso de la complicidad sería prevalente la autoría del art. 416 , porque, entre otras razones, esta calificación permite (como indiqué en la nota anterior) el castigo de la participación de otras personas en ella. 
la completa la irresponsabilidad penal del instrumento, lo que será frecuente en el seno de los delitos contra la administración pública, como el referido ejemplo del delito del art. 413. Situados ante tal hipótesis, parece que la autoría mediata debería ser admitida aun cuando se parta de otras concepciones sobre la autoría, incluso las del dominio del hecho concebido como control del hecho, habida cuenta de que en tal caso la persona de atrás cualificada utiliza a la de delante (no cualificada) como un puro instrumento, que, en rigor, no puede actuar de un modo diferente al que le marca su rol profesional.

Por lo demás, para concluir este epígrafe, baste con dejar constancia de que, aunque descarte la solución de la autoría mediata, la doctrina dominante se ha esforzado en hallar otras vías dogmáticas tendentes a fundamentar la punibilidad de la conducta de la persona de atrás ${ }^{179}$, con el fin de evitar "la absurda impunidad"180 que en otro caso se produciría. Veamos sintéticamente tales vías.

Ante todo, cabe mencionar la vía de acudir a la regla del art. $31 \mathrm{CP}$, que prevé expresamente el supuesto de actuación en nombre o en representación legal o voluntaria de una persona física ${ }^{181}$, entendiendo, por tanto, que el sujeto de delante, que realiza los actos propios del delito especial, está actuando en nombre del sujeto de atrás, en quien concurre la especial cualidad personal descrita en el tipo, y que esta cualidad del intraneus se le transmite al extraneus ${ }^{182}$. De este modo, se podría castigar

179 Se hacen eco también de otras posibles vías, entre otros, MIR, P.G., L.14/60 n. 47; DÍAZ G.-CONLLEDO, 2001, pp. 46 ss., con indicaciones.

180 Cfr. MIR, P.G., L.14/58.

181 Así, vid. especialmente GRACIA, 1985, pp. 111 ss. y 116; HERNÁNDEZ PLASENCIA, 1996, pp. 311 ss. y 318.

182 Cabría, con todo, introducir una matización al hilo de los supuestos usualmente planteados en la doctrina (singularmente en el ámbito de los delitos contra la Administración pública), en el sentido de que la persona de delante, que realiza la materialidad del tipo de acción, podrá ser ya en muchas ocasiones un intraneus, en la medida en que también esta será un funcionario a efectos penales. Así, en el ejemplo del art. 413 planteado por MIR, 
como autor del delito especial propio al sujeto de delante extraneus que realiza la conducta en lugar de la persona de atrás, a pesar de que no concurra en él la característica especial de la autoría recogida en el tipo, la cual sí concurre en el sujeto de atrás intraneus, que entonces podría ser, a su vez, castigado como inductor ${ }^{183}$.

A mi juicio, esta tesis permitiría ciertamente resolver un buen número de supuestos de actuación de intraneus a través del denominado instrumento doloso no cualificado, aunque probablemente no todos podrían solventarse merced a esta cláusula del actuar por otro, so pena de vaciar de contenido la inducción ${ }^{184}$.

Obviamente, habrá que estar al caso concreto, pero, en principio, cabe sostener que, con carácter general, en los denominados delitos especiales propios de posición (sin elementos de infracción de deber), como el referido ejemplo del deudor en el art. 257, entrará siempre en juego la cláusula de extensión de la autoría del art. $31 \mathrm{CP}^{185}$. Incluso en los denominados delitos

lo habitual es que la secretaria sea también funcionaria a efectos penales y que sea posible interpretar asimismo que le incumbe el deber de custodia del documento por razón de su cargo, o, al menos, que ese deber especifico se lo ha transmitido la persona de atrás. Por otra parte, según se indicó más arriba, y como ha apuntado certeramente BOLEA (2000, p. 442), en algunos supuestos la secretaria (no funcionaria) podrá cometer el delito del art. 416 CP (particular encargado accidentalmente de la custodia de documentos), en cuyo caso - añado yo- la persona de atrás (de no admitirse su calificación como autor mediato) podría ser castigada como partícipe en dicho delito con la agravante del art. $22-7^{\mathrm{a}} \mathrm{CP}$.

183 Se produce, así, una inversión de papeles con respecto a lo que sucede en la autoría mediata. En las actuaciones en lugar de otro el (inicialmente) extraneus pasa a ser autor, mientras que el intraneus se convierte en partícipe. Vid. GRACIA, ibid.

184 En este sentido, vid. DÍAZ G.-CONLLEDO, 2001, pp. 46 s., añadiendo que ello solo sería posible si se interpretase la cláusula del art. 31 de modo muy amplio (pero entonces "¿no actuaría todo inducido en nombre o en representación del inductor?"). No obstante, tras calificar esta posibilidad como "muy interesante" (p. 46) entiende DÍAZ que "habrá que probar la solución en diversos delitos y supuestos concretos, pues, con todo, parece la más viable" (p. 47).

185 Vid. MARTÍNEZ-BUJÁN, P.E., p. 76. 
especiales mixtos (con un componente de infracción de deber), o mejor dicho, en delitos especiales con elementos limitadamente personales $^{186}$, cabría aplicar la referida regla si se acoge el criterio del dominio social y se entiende que el extraneus que actúa en lugar del intraneus se halla en "idéntica relación material" con el bien jurídico, en la medida en que el elemento personal, pese a fundamentar la responsabilidad del autor, tiene en el contexto de la realización del hecho típico, una dimensión general, accesible a la responsabilidad de terceros ${ }^{187}$.

Asimismo, al margen ya de la regla del actuar por otro, tampoco veo inconveniente en acudir en determinados supuestos a la estructura de la comisión por omisión, como planteó ya PEÑARANDA en referencia a la autoría de un delito infanticidio (ex art. 410 del CP 1944/73) en el caso de que, para ocultar su deshonra, la madre indujese a un extraneus a dar muerte al hijo recién nacido de la primera o cooperase con él en dicha muerte, a pesar de que fácticamente ha llevado a cabo una conducta activa (de inducción o cooperación) ${ }^{188}$, dado que sería un contrasentido considerar que existe comisión por omisión en los casos en que un garante se limita a no intervenir y que no existe, en cambio, cuando se añade un plus a esa pasividad, agregando a la omisión de impedir el resultado una contribución activa ${ }^{189}$.

186 En el (ya mencionado) sentido propuesto por PEÑARANDA, 2008, pp. 1429 s., y cuyo prototipo serían precisamente los delitos contra la Administración pública.

187 Vid. MARTÍNEZ-BUJÁN, P.G., p. 319 s. y p. 567, en el ejemplo del delito del art. 305.

188 Vid. PEÑARANDA, 1990, p. 357, arguyendo que no se trataba de una autoría mediata con instrumento doloso no cualificado (como pretendía MIR), sino de una autoría en comisión por omisión por parte de un garante (la madre) que está obligado a proteger la vida del recién nacido.

189 Vid. BOLEA, 2000, pp. 441 s., quien, en referencia al delito del art. 413, acertadamente escribe que "si el no evitar el resultado en determinadas condiciones puede llegar a fundamentar una autoría del funcionario en comisión por omisión, con mayor razón habría que admitir esta posibilidad si éste no sólo no evita la destrucción de los documentos que tiene a su cargo, sino que, además, habiendo asumido el compromiso específico de custodiarlos, convence a la secretaria para que los destruya". 
Con todo, no creo que sea esta una solución que pueda generalizarse con el fin de ser aplicada a todos los supuestos que se vienen examinando al hilo de la construcción de la autoría mediata con instrumento doloso no cualificado ${ }^{190}$.

En fin, en cualquier caso, considero que ciertamente, merced a las vías expuestas, podría cubrirse en la mayor parte de los casos (que no en todos) la laguna de punibilidad que algunos penalistas han visto en estos supuestos de la llamada autoría mediata por instrumento doloso no cualificado. Ahora bien, si no se admiten tales soluciones y tampoco se acepta la solución de la autoría mediata que aquí se ha sostenido, habría que proponer de lege ferenda la creación de un precepto concreto en la Parte general, similar al del art. $31 \mathrm{CP}$, pero adaptado al supuesto en comentario, o bien redactando los tipos cuyo contenido material así lo aconseje como auténticos (a mi juicio, puros) delitos de infracción de deber ${ }^{191}$ o con cláusulas que permitan el castigo de la persona de atrás ${ }^{192}$.

\section{Bibliografía}

ALCÁCER GUIRAO, Tentativa y formas de autoría, Madrid 2001.

ANTÓN ONECA, Las estafas y otros engaños, en NEJ, IX, Barcelona 1957.

190 Vid. DÍAZ G.-CONLLEDO, 2001, p. 47, aduciendo que podría intentar generalizarse esta solución para todos los supuestos que la doctrina tradicional resuelve a través de la construcción de la autoría mediata por instrumento doloso no cualificado. Sin embargo, matiza DÍAZ, con razón, que "incluso en el supuesto planteado se pueden mantener reservas frente a dicha solución, según cuál sea el concepto y los requisitos de la comisión por omisión que se consideren correctos; y, sobre todo, parece aún más cuestionable la generalización de la solución a todos los supuestos que la doctrina tradicional resuelve mediante la llamada autoría mediata por instrumento doloso no cualificado".

191 Cfr. DÍAZ G.-CONLLEDO, 2001, p. 47.

192 Por ejemplo: en el art. 325-1 "provoque o realice directa o indirectamente emisiones, vertidos, etc."; en el art. 285 "de forma directa o por persona interpuesta”. Vid. DÍAZ G.-CONLLEDO, 2001, pp. 56 s. 
BOLEA BARDON, Autoría mediata en Derecho Penal, Valencia, 2000.

CEREZO MIR, Curso de Derecho penal español. Parte general, I, Introducción, $6^{\text {a }}$ ed., Madrid 2004.

CEREZO MIR, Curso de Derecho penal español. Parte general, II, Teoría jurídica del delito, 6 6 ed., Madrid 1998 (con adendas de 2004, 2006 y 2007).

CEREZO MIR, Curso de Derecho penal español. Parte general, III, Teoría jurídica del delito/2, Madrid 2001 (con adendas de 2004, 2006 y 2007).

COBO DEL ROSAL/VIVES ANTON, Derecho penal. Parte general, $5^{\text {a }}$ ed., Valencia 1999.

DEMETRIO CRESPO, La tentativa en la autoría mediata y en la actio libera in causa, Granada 2003.

DEMETRIO CRESPO, Sobre la posición de garante del empresario por la no evitación de delitos cometidos pos sus empleados, en J.R. Serrano-Piedecasas y E. Demetrio (dir.) Cuestiones actuales de Derecho penal económico, Madrid 2008.

DEMETRIO CRESPO, Responsabilidad penal por omisión del empresario, Madrid 2009.

DÍAZ GARCÍA-CONLLEDO, La autoría en Derecho penal, Barcelona 1991.

DÍAZ GARCÍA-CONLLEDO, Dominio funcional, determinación positiva y objetiva del hecho y coautoría (comunicación), en Silva Sánchez (ed.), Fundamentos de un sistema europeo del Derecho penal: Libro-homenaje a Claus Roxin, Barcelona, Bosch, 1995.

DÍAZ GARCÍA-CONLLEDO, Autoría y participación (en el nuevo Código penal de 1995), La Ley, no 3.984, 1996-2

DÍAZ GARCÍA-CONLLEDO, Coautoría alternativa y coautoría aditiva: ¿autoría o participación? Reflexiones sobre el concepto de coautoría, en Silva Sánchez (ed.), Política criminal y nuevo Derecho penal: libro homenaje a Claus Roxin, Barcelona, 1997.

DÍAZ GARCÍA-CONLLEDO, Determinación objetiva y positiva del hecho y realización típica como criterios de 
autoría, en Anuario de la Facultad de Derecho de la Universidad de Alcalá de Henares, VIII, 2000.

DÍAZ GARCÍA-CONLLEDO, La autoría mediata. Con una especial referencia a los delitos socioeconómicos y contra el medio ambiente, en Documentos Penales y Criminológicos, vol. 1, 2001.

DÍAZ GARCÍA-CONLLEDO, ¿Es necesaria la cooperación necesaria?, en L.H., Cerezo Mir, Madrid 2002.

DÍAZ GARCÍA-CONLLEDO, ¿Son el dominio funcional del hecho y sus elementos criterios válidos para delimitar la coautoría, la cooperación necesaria y la complicidad? [A la vez, un comentario crítico al libro de PÉREZ ALONSO, Esteban Juan: La coautoría y la complicidad (necesaria) en derecho penal, Granada, 1998], en RDPCr, no 8 (2001-a), 9 y 10 (2002-a).

DÍAZ GARCÍA-CONLLEDO, Autoría, en Enciclopedia Penal Básica (EPB), Granada, 2002-b.

DÍAZ GARCÍA-CONLLEDO, Autoría mediata, coautoría y autoría accesoria, en Enciclopedia Penal Básica (EPB), Granada, 2002-b.

DÍAZ GARCÍA-CONLLEDO, La autoría en Derecho penal. Caracterización general y especial atención al Código Penal colombiano, en Derecho penal y Criminología (Revista del Instituto de ciencias penales y criminológicas de la Universidad externado de Colombia), $\mathrm{n}^{\circ} 76$, 2004.

DÍAZ GARCÍA-CONLLEDO, Problemas actuales de autoría y participación en los delitos económicos, en Nuevo Foro Penal, n 71, 2007.

DÍAZ GARCÍA-CONLLEDO, La influencia de la teoría de la autoría (en especial, de la coautoría) de Roxin en la doctrina y la jurisprudencia españolas. Consideraciones críticas, en Nuevo Foro Penal, Universidad EAFIT, Medellín, $n^{\circ}$ 76, 2011.

DÍAZ GARCÍA-CONLLEDO, Actuación en el marco de un aparato organizado de poder: ¿autoría o participa- 
ción?, en Estudios de Derecho penal. Homenaje al profesor Santiago Mir Puig, Barcelona 2017.

DÍAZ GARCÍA-CONLLEDO, Claus Roxin y la llamada autoría mediata por utilización de aparatos organizados de poder, en Actualidad Penal, (Lima), n 32, 2017-a.

DÍEZ RIPOLLÉS, Una interpretación provisional del concepto de autor, RDPCr, $\mathrm{n}^{\circ} 1,1998$.

DÍEZ RIPOLLÉS, Derecho penal español. Parte general en esquemas, $4^{\mathrm{a}}$ ed., Valencia 2016.

DURÁN SECO, La coautoría en Derecho penal: aspectos esenciales, León 2003.

EURO-DELIKTE (Vorschläge zur Harmonisierung des Wirtschaftsstrafrechts in der Europäischen Union. Allgemeiner und Besonderer Teil), Internationales Symposium Freiburg i Br., 2002.

FARALDO CABANA, Responsabilidad penal del dirigente en estructuras jerárquicas: la autoría mediata con aparatos organizados de poder, Valencia, 2004.

FEIJOO SÁNCHEZ, Derecho penal de la empresa e imputación objetiva, Madrid 2007.

FEIJOO SÁNCHEZ, Imputación de hechos delictivos en estructuras empresariales complejas, LLP, $n^{\circ} 40,2007-b$

FERNÁNDEZ IBÁÑEZ, La autoría mediata en aparatos organizados de poder, Granada, 2006.

GALLEGO SOLER, Criterios de imputación de la autoría en las organizaciones empresariales, en Derecho penal económico, Estudios de Derecho judicial, 72, 2006.

GIMBERNAT ORDEIG, Autor y cómplice en Derecho penal, Madrid 1966.

GIMBERNAT ORDEIG, Delitos cualificados por el resultado y causalidad, Madrid 1966-a.

GIMBERNAT ORDEIG, Gedanken zum Täterbegriff und zur Teilnahmelehre. Eine rechtsvergleichende Abhandlung auf der Grundlage des deutschen und des spanischen Strafrechts, ZStW 80 (1968).

GIMBERNAT ORDEIG, A vueltas con la imputación objetiva, la participación delictiva, la omisión impropia y el 
Derecho penal de la culpabilidad, ADPCP, 2013, vol. LXVI.

GIMBERNAT ORDEIG, Comportamiento típico e imputación del resultado, en LH Mir Puig, Madrid 2017.

GIMBERNAT ORDEIG, EI comportamiento alternativo conforme a Derecho, Buenos Aires, 2017-a.

GÓMEZ RIVERO, Regulación de las formas de participación intentada y de la autoría y participación, La Ley, $n^{\circ} 3959,1996$.

GÓMEZ RIVERO, La inducción a cometer el delito, Valencia 1995.

GONZÁLEZ RUS, Autoría única inmediata, autoría mediata y coautoría, en Cuadernos de Derecho Judicial, 199439, Madrid.

GÓRRIZ ROYO, El concepto de autor en Derecho penal, Valencia 2008.

GRACIA MARTIIN, El actuar en lugar de otro en Derecho penal, I, Zaragoza1985.

GRACIA MARTÍN, El actuar en lugar de otro en Derecho penal, II, Zaragoza 1986.

GRACIA MARTÍN, Responsabilidad de directivos, órganos y representantes de una persona jurídica por delitos especiales, Barcelona 1986-a.

GRACIA MARTÍN, La responsabilidad penal de los administradores y representantes de la empresa por delitos especiales, en J.R. Serrano-Piedecasas y E. Demetrio (dir.) Cuestiones actuales de Derecho penal empresarial, Madrid 2010.

HERNÁNDEZ PLASENCIA, La autoría mediata en Derecho penal, Granada 1996.

HERNÁNDEZ PLASENCIA, "Imputación objetiva versus dominio del hecho", en Díez Ripollés (coord.), La ciencia del Derecho penal ante el nuevo siglo: libro homenaje al profesor doctor don José Cerezo Mir, Madrid 2002.

HERZBERG, Grundfälle zur Lehre von Täterschaft und Teilnahme, JuS, 1974. 
HERZBERG, Täterschaft und Teilnahme, München 1977.

HERZBERG, Täterschaft, Mittäterschaft und Akzessorietät der Teilnahme, en ZStW, 1987.

JAKOBS, Strafrecht: Allgemeiner Teil, 2a ed., Berlin 1991.

LÓPEZ PEREGRÍN, La complicidad en el delito, Valencia 1997.

LÓPEZ BARJA DE QUIROGA, Autoría y participación, Madrid 1996.

LUZÓN PEÑA, La "determinación objetiva del hecho". Observaciones sobre la autoría en delitos dolosos e imprudentes de resultado, en ADP 1989 y en Derecho penal de la circulación, $2^{\mathrm{a}}$ ed., 1990.

LUZÓN PEÑA, 1991, ¿???

LUZÓN PEÑA, Curso de Derecho penal. Parte general, I, Madrid 1996.

LUZÓN PEÑA, Lecciones de Derecho penal. Parte General, $3^{\mathrm{a}}$ ed., Valencia 2016.

LUZÓN PEÑA, Equivalencia de la omisión a la comisión: creación o aumento del peligro por la omisión misma en la comisión por omisión. Un esbozo, en Libertas, $\mathrm{n}^{\mathrm{0}}$ 5, 2016.

LUZÓN PEÑA, Omisión impropia o comisión por omisión. Cuestiones nucleares: imputación objetiva sin causalidad, posiciones de garante, equivalencia (concreción del criterio normativo de la creación o aumento de peligro o riesgo) y autoría o participación, en Libertas, $n^{\circ} 6,2017$.

LUZÓN PEÑA/DÍAZ GARCÍA-CONLLEDO, Determinación objetiva y positiva del hecho y realización típica como criterios de autoría, en Derecho penal contemporáneo (Revista internacional), Colombia, enero-marzo 2003 (=Objektive positive Tatbestimmung und Tatbestandsverwiklichung als Täterschaftsmerkmale", en Schünemann (dir.), Festschrift für Claus Roxin, Berlin 2001).

MAQUEDA ABREU, Los delitos de propia mano, Madrid 1992. 
MARAVER GÓMEZ, Concepto restrictivo de autor y principio de auto-responsabilidad, en Jorge Barreiro (coord.), Homenaje al profesor Dr. Gonzalo Rodríguez Mourullo, Madrid 2005.

MARÍN DE ESPINOSA CEBALLOS, Criminalidad de empresa. La responsabilidad penal en las estructuras jerárquicamente organizadas, Valencia 2002.

MARTÍNEZ-BUJÁN PÉREZ, EI contenido de la antijuridicidad (Un estudio a partir de la concepción significativa del delito), Valencia 2013.

MARTÍNEZ-BUJÁN PÉREZ, Los elementos subjetivos del tipo de acción, en teoría \& derecho, n¹3, 2013-a.

MARTÍNEZ-BUJÁN PÉREZ, Del incumplimiento del deber de vigilancia o control en personas jurídicas y empresas (EI artículo 286 seis del Proyecto de Ley Orgánica de Código penal español de 2013), en Libertas, $\mathrm{n}^{0} 3$, 2015.

MARTIINEZ-BUJÁN PÉREZ, Derecho penal económico y de la empresa. Parte Especial, 5a ed., Valencia 2015.

MARTÍNEZ-BUJÁN PÉREZ, Derecho penal económico y de la empresa. Parte General, $5^{\text {a }}$ ed., Valencia 2016.

MARTÍNEZ-BUJÁN PÉREZ, El error en la teoría jurídica del delito (Un estudio a la luz de la concepción significativa), Valencia 2017.

MARTIINEZ-BUJÁN PÉREZ, Notas básicas sobre la autoría a la luz de la concepción significativa de la acción (y de la regulación del CP español), en el Libro Homenaje al Prof. Juan Terradillos Basoco, 2018.

MARTIINEZ-BUJÁN PÉREZ, Autoría y realización/ejecución (objetiva y positiva) del significado específico del hecho. Un estudio a la luz de la concepción significativa de la acción (y de la regulación del CP español) en el Libro Homenaje al Prof. Lorenzo Morillas Cueva, 2018.

MEINI, El dominio de la organización en Derecho penal, Lima 2008. 
MIR PUIG, Función de la pena y teoría del delito en el Estado social y democrático de Derecho, $2^{\mathrm{a}}$ ed., Barcelona 1982.

MIR PUIG, Derecho penal. Parte general, $10^{\mathrm{a}}$ ed., (con la colaboración de Gómez Martín, Víctor/Valiente Iváñez, Vicente), Barcelona 2015.

MIRÓ LLINARES, Derecho penal económico-empresarial y evolución de la teoría del delito en la jurisprudencia del T.S., I, Tipo objetivo, II, Tipo subjetivo, III, Intervención delictiva, en J.M ${ }^{\mathrm{a}}$. Silva y F. Miró (dirs.) $L a$ teoría del delito en la práctica penal económica, Madrid 2013-b.

MOLINA FERNÁNDEZ, Antijuridicidad penal y sistema del delito, Barcelona 2001.

MOLINA FERNÁNDEZ, EI razonable "regreso" del dolo a la culpabilidad, en LH Mir Puig, Madrid 2017.

MONTANER FERNÁNDEZ: Gestión empresarial y atribución de responsabilidad penal. A propósito de la gestión medioambiental, Barcelona 2008.

MUÑOZ CONDE, Problemas de autoría y participación en el Derecho penal económico, o ¿cómo imputar a título de autores a las personas que, sin realizar acciones ejecutivas, deciden la realización de un delito en el ámbito de la delincuencia económica empresarial?, en el libro "Derecho penal económico", C.G.P.J., Madrid 2001, (también en RP, no 9, 2002).

MUÑOZ LORENTE, La exención de responsabilidad por delito ecológico de los empleados subalternos que materialmente realizan los vertidos objeto del delito, (comentario a la STS 13-3-2000), en RGA, ${ }^{\circ}$ 22, 2000. MURMANN, Tätherrschaft durch Weisungsmacht, en GA, 1996.

OCTAVIO DE TOLEDO Y UBIETO, La autoría conforme al Código penal, en LH Valle Muñiz, Elcano 2001.

OCTAVIO DE TOLEDO Y UBIETO, Algunas cuestiones sobre autoría, participación, tentativa, peligro e impru- 
dencia, a propósito de la "responsabilidad penal por el producto", en LH Ruiz Antón, Valencia 2004.

ORTS BERENGUER/GONZÁLEZ CUSSAC, Compendio de Derecho penal, Parte general, Valencia 2004, y $7^{\mathrm{a}}$ ed., 2017.

PEÑARANDA RAMOS, La participación en el delito y el principio de accesoriedad, Madrid 1990.

PEÑARANDA RAMOS, "Sobre el alcance del art. 65.3 CP: al mismo tiempo: una contribución a la crítica de la teoría de los delitos de infracción de deber", en García Valdés y otros (Coord.), Estudios penales en homenaje a Enrique Gimbernat, Madrid 2008.

PÉREZ ALONSO, La coautoría y la complicidad (necesaria) en el CP, Granada 1998.

PÉREZ MANZANO, Autoría y participación imprudente en el Código penal de 1995, Madrid 1999.

PUENTE ABA, Delitos económicos contra los consumidores y delito publicitario, Valencia 2002.

QUINTERO OLIVARES, Los delitos especiales y la teoría de la participación, Barcelona 1974.

RAGUÉS VALLĖS, Los elementos subjetivos no escritos: ¿hacia su definitiva desaparición? en LH Santiago Mir Puig, Barcelona 2017.

RENZIKOWSKI, Restriktiver Täterbegriff und fahrlässige Beteiligung, Tübingen 1997.

ROBLES PLANAS, La participación en el delito: fundamento y límites, Madrid 2003.

ROBLES PLANAS, Garantes y cómplices, Barcelona 2007.

RODRÍGUEZ MOURULLO, La omisión de socorro en el Código penal, Madrid 1966.

RODRÍGUEZ MOURULLO, EI autor mediato en Derecho penal español, en ADPCP, 1969.

RODRÍGUEZ MOURULLO, en J. Córdoba/G. Rodríguez Mourullo, Comentarios al Código penal, t. I, Barcelona 1972.

RODRÍGUEZ MOURULLO, Derecho penal. Parte general, Madrid 1978. 
ROSO CAÑADILLAS, Autoría y participación imprudente, Granada 2002.

ROXIN, Täterschaft und Tatherrschaft, 7. Aufl., Berlin 2000. Hay traducción de J. Cuello Contreras y J.L. Serrano, $A u$ toría y dominio del hecho, Madrid 2000.

ROXIN, Las formas de intervención en el delito: estado de la cuestión, en J.M Silva Sánchez (ed.) Sobre el estado de la teoría del delito, Madrid 2000-a.

ROXIN, Strafrecht. Allgemeiner Teil, Band II, München, 2003 (hay trad. española y notas por D.-M. Luzón Peña, dir., J. M. Paredes Castañón, M. Díaz García-Conlledo, J. de Vicente Remesal y otros), Madrid 2014.

ROXIN, Strafrecht. Allgemeiner Teil, Band I, 4. Aufl., München 2006 (hay trad. española a la $2^{\mathrm{a}}$ ed. alemana y notas por D.-M. Luzón Peña, dir., M. Díaz García-Conlledo y J. de Vicente Remesal) Madrid 1997.

SAINZ-CANTERO CAPARRÓS, La "codelincuencia" en los delitos imprudentes en el Código penal de 1995, Madrid 2001.

SCHÜNEMANN, Sobre la regulación de los delitos de omisión impropia en los eurodelitos, en Tiedemann/Nieto (ed.) Eurodelitos. El Derecho penal económico en la UE, Cuenca 2003.

SCHÜNEMANN, El dominio sobre el fundamento del resultado: base lógico-objetiva común para todas las formas de autoría, incluyendo el actuar en lugar de otro, en L.H. Rodríguez Mourullo, Madrid 2005.

SILVA SÁNCHEZ, El nuevo Código penal: cinco cuestiones fundamentales, Barcelona 1997.

SILVA SÁNCHEZ, Delitos contra el medio ambiente, Valencia 1999.

SILVA SÁNCHEZ, Teoría del delito y Derecho penal económico empresarial, en J.Ma. Silva y F. Miró (dirs.) $L a$ teoría del delito en la práctica penal económica, Madrid 2013-b.

TIEDEMANN, La regulación de la autoría y la participación en el Derecho penal europeo, RP, $n^{\circ}$ 5, 2000. 
TIEDEMANN/NIETO, Eurodelitos. EI Derecho penal económico en la Unión Europea, Cuenca 2003.

VIVES ANTÓN, Libertad de prensa y responsabilidad criminal, Madrid 1977.

VIVES ANTÓN, Fundamentos del sistema penal, Valencia 1996.

VIVES ANTÓN, Comentarios al código penal de 1995, tomos I y II, (T. Vives, coord.), Valencia 1996-a.

VIVES ANTÓN, Principios penales y dogmática penal, en VIVES/MANZANARES (dir.) Estudios sobre el Código penal de 1995, Madrid 1996-b.

VIVES ANTÓN, Derecho penal. Parte general, (COBO DEL ROSAL/VIVES ANTON), 5a ed., Valencia 1999.

VIVES ANTÓN, El principio de culpabilidad, en L.H. Cerezo, Madrid 2002.

VIVES ANTÓN, Fundamentos del sistema penal (Acción Significativa y Derechos constitucionales), $2^{\text {a }}$ edición, Valencia 2011. 